\title{
Revision of the morphology, phylogenetic relationships, behaviour and diversity of the Iberian and Italian ant-like Tachydromia Meigen, 1803 (Diptera: Hybotidae)
}

\author{
Ana Rita GONÇALVES ${ }^{1, *}$, Patrick GROOTAERT ${ }^{2}$, Rui ANDRADE ${ }^{3}$, \\ Octávio S. PAULO ${ }^{4} \&$ Ximo MENGUAL ${ }^{5}$ \\ ${ }^{1,4}$ Computational Biology and Population Genomics Group, cE3c, Faculdade de Ciências, \\ Universidade de Lisboa, Campo Grande, 1749-016 Lisboa, Portugal. \\ ${ }^{2}$ Royal Belgian Institute of Natural Sciences, Brussels, Belgium and Lee Kong Chian Natural History \\ Museum, National University of Singapore, Singapore. \\ ${ }^{3}$ Rua Calouste Gulbenkian 237 4H3, 4050-145 Porto, Portugal. \\ ${ }^{5}$ Zoologisches Forschungsmuseum Alexander Koenig, Leibniz-Institut für Biodiversität der Tiere, \\ Adenauerallee 160, 53113, Bonn, Germany. \\ "Corresponding author: ana.goncalves@mail.mcgill.ca \\ ${ }_{2}^{2}$ Email: pgrootaert@yahoo.co.uk \\ ${ }^{3}$ Email: ruiamandrade@yahoo.com \\ ${ }^{4}$ Email: ofpaulo@fc.ul.pt \\ ${ }^{5}$ Email: X.Mengual@leibniz-zfmk.de

\footnotetext{
${ }^{1}$ urn:lsid:zoobank.org:author:1A0C6FC2-1273-4DFD-A306-874D90860F61

${ }^{2}$ urn:1sid:zoobank.org:author:B80BC556-9087-4D0D-9D69-7FA9BE5779C4

${ }^{3}$ urn:1sid:zoobank.org:author:36D41774-1466-4297-BB51-CCCEEE6DCB4E

${ }^{4}$ urn:lsid:zoobank.org:author:2F8855AC-67EC-47BC-ADF5-019EAF332A7A

${ }^{5}$ urn:lsid:zoobank.org:author:A509310D-B567-4830-B8A4-BCB139BB8768
}

\footnotetext{
1 - https://orcid.org/0000-0003-1776-3728

2 ○ https://orcid.org/0000-0003-2149-9229

${ }^{3} \odot$ https://orcid.org/0000-0003-2356-3706

4 @ https://orcid.org/0000-0001-5408-5212

5 은ttps://orcid.org/0000-0002-6185-9404
}

\begin{abstract}
Phylogenetic inference, based on five molecular markers (COI, 28S, AATS, 12S, PGD), corroborates the synonymy of the flightless genera Pieltainia Arias, 1919 and Ariasella Gil, 1923 with Tachydromia Meigen, 1803. The secondary structure of the 28S rRNA gene is used for the first time in this family to align the multiple sequences. Molecular and morphological data are largely congruent for all known species of flightless Tachydromia. This paper treats ten western Mediterranean species (nine Iberian and one Italian) in detail, including the description of four new species: T. ebejeri Gonçalves, Grootaert \& Andrade sp. nov., T. stenoptera Gonçalves, Grootaert \& Andrade sp. nov., T. cantabrica Gonçalves, Grootaert \& Andrade sp. nov. and T. nigrohirta Gonçalves, Grootaert \& Andrade sp. nov. The male of Tachydromia pieltaini (Gil Collado, 1936) and the female of Tachydromia apterygon
\end{abstract}


Plant \& Deeming, 2006 are described for the first time, while a lectotype is assigned to Tachydromia pandellei (Séguy, 1941). A key to all non-macropterous Tachydromia is supplied. Knowledge on the geographic distribution of most species is considerably enhanced. The mating behaviour of Tachydromia semiaptera (Gil Collado, 1923) and Tachydromia iberica (Arias, 1919) is documented for the first time, and we propose a change in the definition of terms apterous and micropterous to properly accommodate the diversity of wing states in this cluster of species.

Keywords. Iberian Peninsula, Hybotidae, flightless, molecular phylogeny, synonym, new species.

Gonçalves A.R., Grootaert P., Andrade R., Paulo O.S. \& Mengual X. 2021. Revision of the morphology, phylogenetic relationships, behaviour and diversity of the Iberian and Italian ant-like Tachydromia Meigen, 1803 (Diptera: Hybotidae). European Journal of Taxonomy 732: 1-56. https://doi.org/10.5852/ejt.2021.732.1213

\section{Table of Contents}

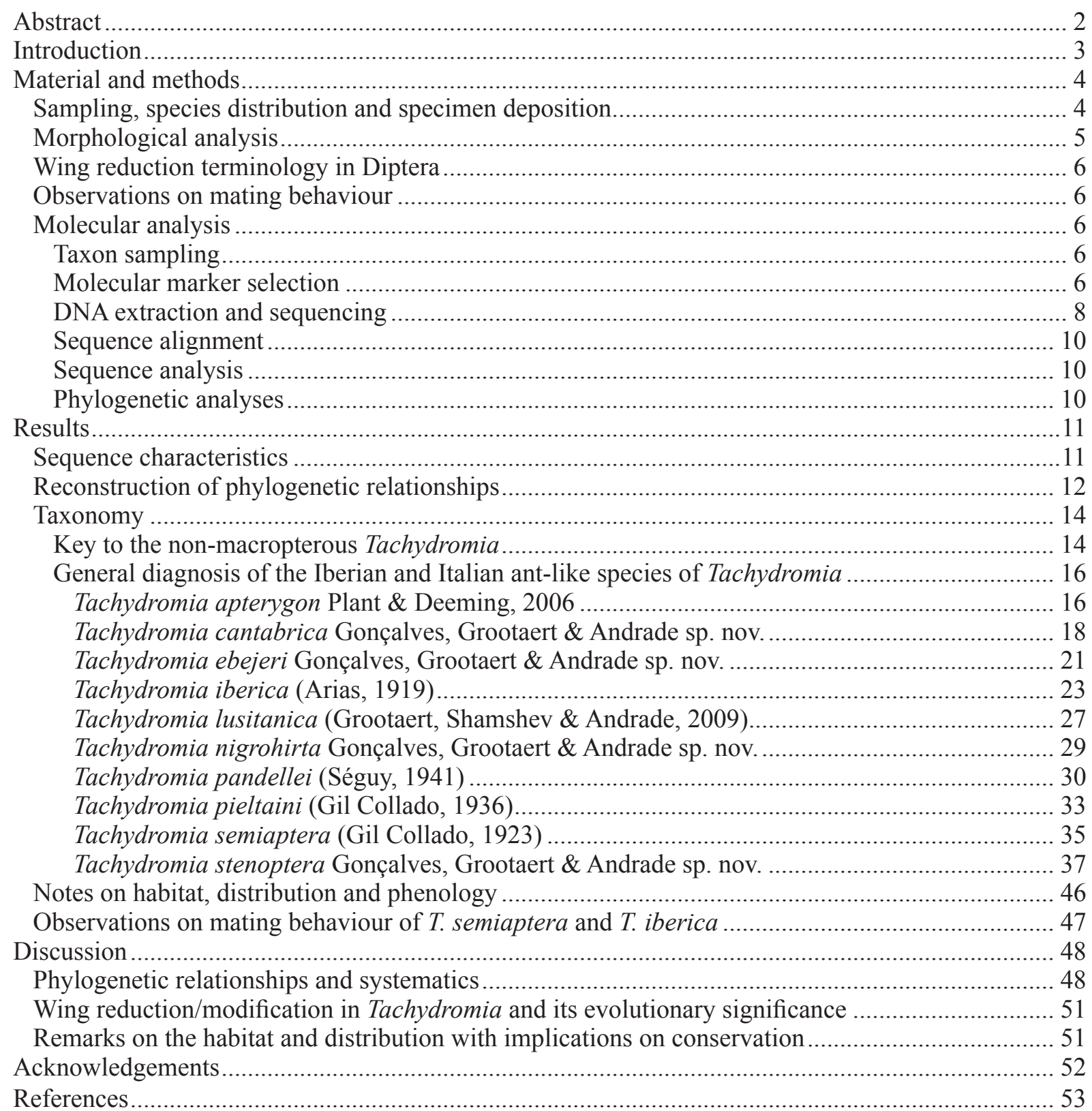




\section{Introduction}

The genus Tachydromia Meigen, 1803 (Diptera Linnaeus, 1758, Hybotidae Meigen, 1820) includes over 100 valid species distributed worldwide, most of them described in the temperate areas of the Holarctic region (Shamshev \& Grootaert 2018). These are small-bodied flies (1-3.5 mm) usually shiny black to blackish brown in colour, with dark banded or clouded wings (Chvála 1975). This genus is currently divided into nine species groups based on morphological characters: the annulimana, arrogans, calcanea, connexa, interrupta, ornatipes, punctifera and terricola groups (Chvála 1970, 1975; Stark \& Doczkal 2017).

This paper reviews the flightless Tachydromia from the western Mediterranean, the Iberian Peninsula and Italy, comprising ten species in total, including four newly described species from Iberia. They are minute ant-like flies, ca $2.5 \mathrm{~mm}$, which occupy specific microhabitats among the leaf litter of deciduous forests. One of these ant-like Tachydromia, Tachydromia apterygon Plant \& Deeming 2006, is endemic to Italy, while the remaining nine species are restricted to the Iberian Peninsula and the Pyrenees.

Apart from Tachydromia apterygon, which has scale-like wings in both sexes and lacks halteres, five of these species were originally placed in the genera Pieltainia Arias, 1919 and Ariasella Gil Collado, 1923, but these two genera have since been placed in synonymy with Tachydromia (Shamshev \& Grootaert 2018): Tachydromia iberica (Arias, 1919), Tachydromia semiaptera (Gil Collado, 1923), Tachydromia pieltaini (Gil Collado, 1936), Tachydromia pandellei (Séguy, 1941) and the more recently described Tachydromia lusitanica (Grootaert, Shamshev \& Andrade, 2009). Despite being morphologically similar to Tachydromia, they were originally assigned to the above-mentioned genera solely based on the complete absence of halteres and on the extremely reduced or absent wings. The former monospecific Pieltainia was characterized by aptery in both sexes, while in Ariasella spp. males are stenopterous, i.e., very narrow but long wings (complete loss of flight ability) (Figs 20E, 21A-B, D). The males of the species previously placed in Ariasella have tubular, stalk-like wings with a lobed tip, which, at least in T. lusitanica, are waved during mating (Andrade 2011). Females of both T. semiaptera and T. lusitanica are micropterous (Figs 20F, 21E), with wings reduced to a minute bilobed scale, while females of T. pandellei and T. pieltaini are stenopterous but lack the developed lobed tip present in males (Fig. 21C).

To our knowledge, there is no published information on the immature stages, but adult Tachydromia are predators of small flies, mostly soft-bodied 'nematocera'. They are commonly encountered in large numbers, swiftly running either on vertical or horizontal surfaces such as tree trunks, logs, low vegetation and river margins (Chvála 1970), and often even fully winged species are reluctant to fly, but instead run to avoid predators. In addition to the Iberian and Italian ant-like species, frequent cursorial habits are also taken to an extreme in only three other previously described species of Tachydromia. These have evolved to become completely flightless by lacking functional wings, while still conserving the halteres: Tachydromia rossica Shamshev, 1994 (Russian Far East and Mongolia) has stalk-like wings, without the lobed tip whereas Tachydromia microptera (Loew, 1864) and Tachydromia schnitteri Stark, 1996 (central Europe) are brachypterous (venation and shape similar to macropterous Tachydromia). However, wing reduction is present in at least 20 dipteran families (Hackman 1964) and it is frequent in Hybotidae (Grootaert \& Shamshev 2008). This phenomenon may be explained by several factors, including the stability of the habitat and cryptic behaviour (Hackman 1964).

Due to a combination of their small size, cryptic habitat preferences and relatively short period of activity, most Iberian ant-like species of Tachydromia have been poorly studied at the morphological, behavioural, systematic and ecological levels. The original descriptions were generally superficial and lacked information on important taxonomic characters, such as the male terminalia. The species distribution was also only known from either the type locality, or just a few localities, generally based on 
a few specimens, and in the case of T. pieltaini, only the female was known and described. Additionally, the types of T. iberica, T. semiaptera and T. pieltaini seem to be lost and no holotype was assigned to T. pandellei. There is, however, a noteworthy exception to this scenario that is the case of T. lusitanica, whose description includes the male terminalia and other important details of taxonomic relevance. Furthermore, several important observations on its behaviour were published by Andrade (2011). The only other observations were the brief notes by Arias (1919) on Tachydromia iberica, describing its great voracity by preying on fungus gnats (Diptera, Sciaridae Billberg, 1820) and its agility, resembling small ants quickly running on the ground. A close phylogenetic relationship between Ariasella and Tachydromia was recovered by J. Mortelmans (MSc thesis, unpublished data) using several genes (COI, 18S, 28S, EF-1 alpha and PGD). In this study, the single studied species of 'Ariasella', currently T. pieltaini, was resolved embedded among species of Tachydromia. Nagy et al. (2013) resolved T. pieltaini again within the studied species of Tachydromia in a simple Neighbour-Joining tree reconstruction using the 5'-end of the mitochondrial COI gene. Until now, T. iberica (previously regarded as the monotypic genus Pieltainia), has not been included in any phylogenetic inferences.

In the present study we pursue a more inclusive phylogenetic analysis by including all species previously regarded as Ariasella, Tachydromia iberica from three geographically distant localities, and four newly described species. We used five different molecular markers: the entire mitochondrial protein-coding gene of the cytochrome c oxidase subunit I (COI), the partial mitochondrial ribosomal 12S rRNA gene, the partial nuclear protein-coding genes PGD and AATS, and the partial nuclear ribosomal 28S rRNA gene. Furthermore, the present study uses a modern morphological analysis (e.g., by including SEM imaging) in the (re)description of the target taxa, including in the description of the male of T. pieltaini, and a lectotype for T. pandellei is designated. Additionally, we considerably improve the knowledge on the geographic distribution of these species as well as provide new observations on mating behaviour. This research has the overall aims of: i) describing new flightless ant-like Iberian species; ii) inferring the phylogenetic relationships among the flightless ant-like Iberian species; iii) understanding the phylogenetic relationship between Tachydromia and the species previously placed in genera Pieltainia and Ariasella; and finally iv) shedding light on the wing evolution of the ant-like Iberian species.

\section{Material and methods}

\section{Sampling, species distribution and specimen deposition}

Specimens were manually collected with a vial after being directly searched for on the leaf litter. Afterwards, they were preserved either dry-mounted, in $70 \%$ ethanol or absolute ethanol (for molecular analysis). In the cases where type material is lost, species were identified based on the illustrations and on the original descriptions previously published (Arias 1919; Gil 1923, 1936; Séguy 1941; Plant \& Deeming 2006; Grootaert et al. 2009). In most cases, additional specimens were collected at their type localities or very close by. Distribution data was compiled from published records and based on recent sampling efforts. Several sampling expeditions took place across the Iberian Peninsula and the Pyrenees (Fig. 1) as well as the Apennine Mountains, mostly from January to July (2013-2018). Historical and new occurrence records were plotted using QGIS ver. 2.18.16, with the coordinates projected in the reference system Madrid 1870 (Madrid), code 4903. The raster map dataset (Natural Earth II with Shaded Relief, Water, and Drainages) was obtained from https://www.naturalearthdata.com.

The abbreviations for the specimen repositories are:

NHMUK $=$ The Natural History Museum, London, United Kingdom

NMWC $=$ National Museum of Wales, Cardiff, United Kingdom

RBINS $=$ Royal Belgian Institute of Natural Sciences, Brussels, Belgium

ZFMK = Zoologisches Forschungsmuseum Alexander Koenig, Bonn, Germany

Specimens not assigned to a formal repository are placed in the first author's collection. 


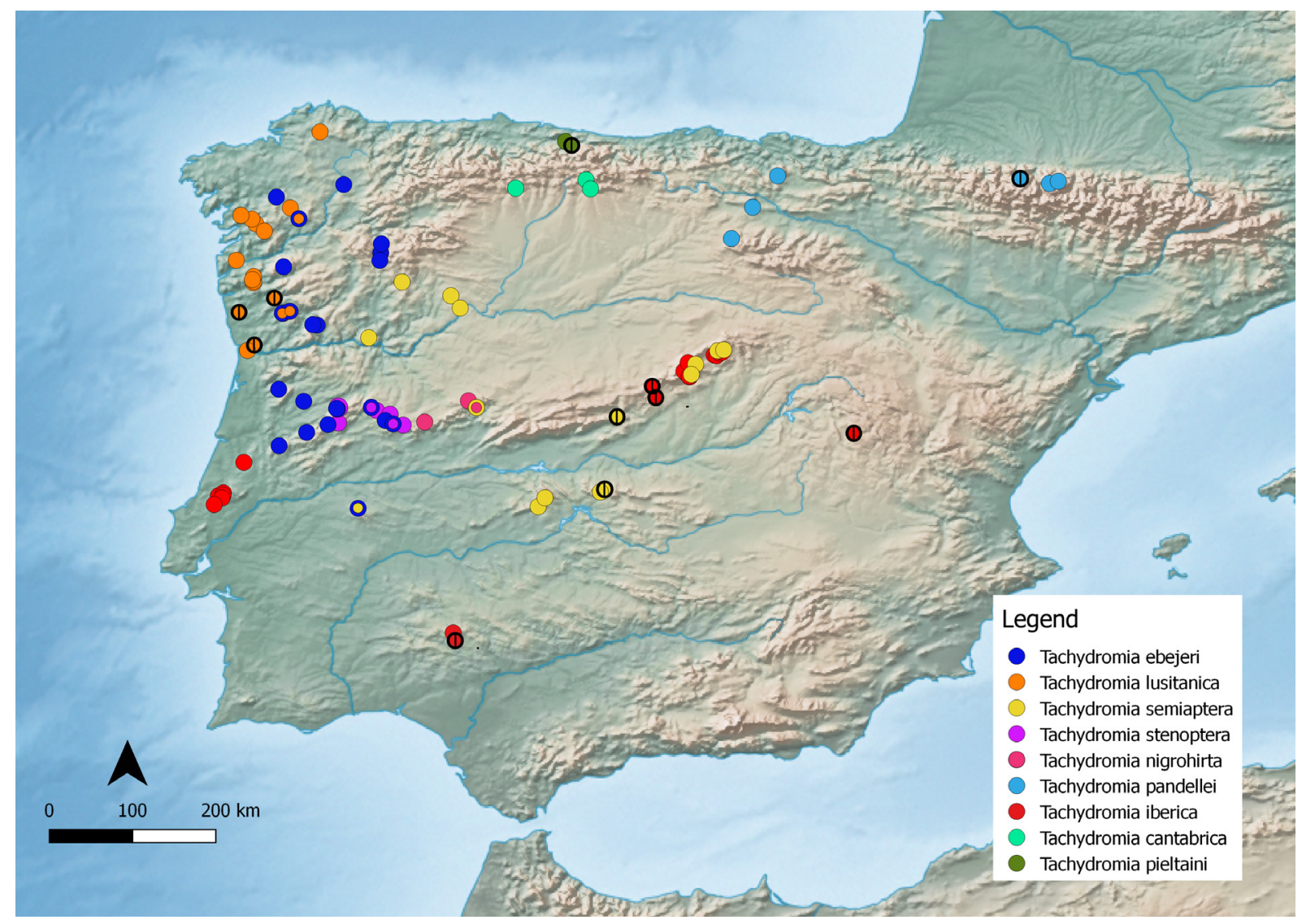

Fig. 1. Currently known distribution of the Iberian ant-like Tachydromia Meigen, 1803. Each dot represents a presence point, with each colour corresponding to a different species. When two species co-occur in the same area, their presence is represented by a smaller dot on top of a dot of regular dimension, each of those with the colour corresponding to the co-occurring species. The dots surrounded by a black circle with a vertical line represent localities previously known.

\section{Morphological analysis}

Terms used for adult structures follow those of Cumming \& Wood (2017). Male terminalia were macerated in hot (around $90^{\circ} \mathrm{C}$ ) $10 \% \mathrm{KOH}$ for 10 minutes and left at room temperature for several hours, cleared in ethanol and immersed in glycerine for long-term preservation. Drawings of the terminalia were made with a camera lucida attached to a Leitz Laborlux 12 compound microscope. Drawings of the wing were made based on direct observation by using a stereo microscope, SteREO Lumar.V12 (Carl Zeiss MicroImaging). Images of minute wings and spurs were obtained using a scanning electron microscope JSM-5200LV (JEOL, Ltd). Photographs of pinned specimens were taken with a Canon EOS 7D mounted on a P-51 Cam-Lift (Dun Inc.) and exported with the help of Adobe Lightroom (ver. 5.6). Afterwards, the images were stacked using the software Zerene Stacker ver. 1.04. Photographs of live specimens were taken with a Fujifilm FinePix HS10, with a Raynox DCR-250 macro lens.

The body length was measured from the frons to the end of the terminalia in lateral view. The wing length was measured from the wingtip to its base. Measurements were taken using dried specimens. In the descriptions, the right and left side of the male terminalia are based on the unrotated position viewed posteriorly, such that in the illustrations the right surstylus appears on the reader's left side and vice versa. All male terminalia are figured in their unrotated position. 


\section{Wing reduction terminology in Diptera}

Hackman (1964) proposed a terminology regarding the degree of wing reduction in Diptera. Brachypterous means reduced wing, shorter than abdomen, broad and more or less blunt, not permitting flight, with at least radial veins distinct. Stenopterous are specimens with wings very narrow but sometimes long, not permitting flight, with at least radial veins distinct. Micropterous are species with wing reduced to small appendage of varying shape with at most traces of the radial vein. And, finally, apterous species have wings at most represented by a minute scale, at most carrying some setae or totally absent. Recently, Roháček (2012) added the term submacropterous for species with wings similarly shaped, including venation, as in normal macropterous specimens, but distinctly shorter, darker, about as long as the abdomen. Here, we propose an emendation to this terminology where the term micropterous assumes a more inclusive definition: wing reduced to a small appendage, stub or minute scale, of varying shape with at most traces of the radial veins present. Furthermore, we change the term apterous, with its definition being restricted to wings totally absent, without any traces of its presence.

\section{Observations on mating behaviour}

Observations in captivity were made for Tachydromia semiaptera (population of Spain, Cáceres, Las Villuercas) and Tachydromia iberica (population of Portugal, Leiria, Arrimal). These species were selected because of their level of wing reduction: the former species is stenopterous, with very flexible stalk-like wings (in opposition to the rigid wings of the other stenopterous Iberian ant-like species); and the latter is apterous. The mating behaviour of a stenopterous species with rigid stalk-like wings, T. lusitanica, was described by Andrade (2011). Specimens were kept in a small terrarium $(27 \times$ $15 \times 17 \mathrm{~cm}$ ), with a section of $4 \mathrm{~cm}$ deep soil, including leaf litter. In two separated instances, each species $(10 \widehat{\partial} \widehat{\partial}, 10$ 웅) was kept and observed for five consecutive days. Observations were made using a Fujifilm FinePix HS20 EXR, with a Raynox DCR-250 macro lens. Specimens of Sciaridae were offered as a food source. To test intraspecific interactions in pre-defined conditions (e.g., quantity of specimens, sex), specimens were temporarily taken from the terrarium and put inside transparent plastic vials. Various types of interactions were observed but here, only the mating behaviour is described because of its relevance to help understand the evolutionary importance of wing reduction/modification. These observations were aimed at obtaining qualitative descriptions of behaviour.

\section{Molecular analysis}

\section{Taxon sampling}

The taxon sampling included 35 specimens belonging to 31 different species: 30 Hybotidae and one Empididae Latreille, 1809. We sequenced and analysed for the first time nine species of Tachydromia, namely eight Iberian ant-like Tachydromia as well as Tachydromia apterygon. In other words, the analysis covered all the nine previously described and newly described species of the Iberian flightless ant-like Tachydromia. Additionally, it included four macropterous and one apterous species of Tachydromia assigned to three species-groups sensu Chvála (1970): the terricola, connexa and arrogans groups. The abovementioned taxa constitute the ingroup. Representatives of each of the six subfamilies of Hybotidae were included as outgroups, as were the tribes within Tachydromiinae sensu Sinclair \& Cumming (2006). Empis tessellata Fabricius, 1794 (Empididae) was used to root the tree. Table 1 lists the species included in the analysis, as well as the collection data. The samples were made available either by obtaining freshly collected specimens or from the German Barcode of Life (GBOL) DNA collection preserved in the ZFMK BioBank.

\section{Molecular marker selection}

Three nuclear genes (28S, PGD, AATS) and two mitochondrial genes (COI and 12S) were selected to be sequenced. The choice of these genes was based on their different evolutionary rates and on the existence of primers (Table 2) used in groups of insects, including some specific for Diptera. 
Table 1 (continued on next page). Taxon sampling used in the molecular analysis. The cross (X) denotes success in obtaining a sequence of the respective molecular marker.

\begin{tabular}{|c|c|c|c|c|c|c|c|c|c|}
\hline Species & $\begin{array}{l}\text { DNA voucher } \\
\text { ZMFK }\end{array}$ & Label information & $\begin{array}{c}\text { GBOL catalogue } \\
\text { number }\end{array}$ & COI-5' & COI-3', & $28 \mathrm{~S}$ & AATS & $12 S$ & PGD \\
\hline $\begin{array}{l}\text { Tachydromia } \\
\text { ebejeri } \text { sp. nov. }\end{array}$ & AR01 & $\begin{array}{l}\text { Portugal: Sabugal, } 1 \text { Apr. } 2017 . \\
\text { Leg: A. Gonçalves \& R. Andrade }\end{array}$ & - & $\mathrm{X}$ & $\mathrm{X}$ & $\mathrm{X}$ & $\mathrm{X}$ & $\mathrm{X}$ & $\mathrm{X}$ \\
\hline $\begin{array}{l}\text { Tachydromia } \\
\text { stenoptera } \text { sp. nov. }\end{array}$ & AR02 & $\begin{array}{l}\text { Portugal: Guarda, Adão, } \\
1 \text { Apr. } 2017 . \\
\text { Leg: A. Gonçalves \& R. Andrade }\end{array}$ & - & $\mathrm{X}$ & $\mathrm{X}$ & $\mathrm{X}$ & $\mathrm{X}$ & $\mathrm{X}$ & $\mathrm{X}$ \\
\hline $\begin{array}{l}\text { Tachydromia } \\
\text { nigrohirta } \text { sp. nov. }\end{array}$ & AR03 & $\begin{array}{l}\text { Spain: Salamanca, El Maíllo, } \\
25 \text { Apr. 2017. Leg: A. Gonçalves }\end{array}$ & - & $\mathrm{X}$ & $\mathrm{X}$ & $\mathrm{X}$ & $\mathrm{X}$ & $\mathrm{X}$ & - \\
\hline $\begin{array}{l}\text { Tachydromia } \\
\text { lusitanica }\end{array}$ & AR04 & $\begin{array}{l}\text { Portugal: Fafe, Felgueiras, } \\
9 \text { Apr. 2017. Leg: R. Andrade }\end{array}$ & - & $\mathrm{X}$ & $\mathrm{X}$ & $\mathrm{X}$ & $\mathrm{X}$ & $\mathrm{X}$ & $\mathrm{X}$ \\
\hline $\begin{array}{l}\text { Tachydromia } \\
\text { pandellei }\end{array}$ & AR05 & $\begin{array}{l}\text { France: Hautes-Pyrénées, } \\
\text { Arrens-Marsous, Arrens, } \\
\text { Route d'Aste, } 19 \text { Jun. } 2017 . \\
\text { Leg: A. Gonçalves \& E. Marabuto }\end{array}$ & - & $\mathrm{X}$ & $\mathrm{X}$ & $\mathrm{X}$ & $\mathrm{X}$ & $\mathrm{X}$ & $\mathrm{X}$ \\
\hline $\begin{array}{l}\text { Tachydromia } \\
\text { semiaptera }\end{array}$ & AR06 & $\begin{array}{l}\text { Spain: Ávila, ElBarraco, } \\
13 \text { Apr. } 2016 . \\
\text { Leg:A. Gonçalves \& R. Andrade }\end{array}$ & - & $\mathrm{X}$ & $\mathrm{X}$ & $\mathrm{X}$ & $\mathrm{X}$ & $\mathrm{X}$ & $\mathrm{X}$ \\
\hline $\begin{array}{l}\text { Tachydromia } \\
\text { iberica }\end{array}$ & AR07 & $\begin{array}{l}\text { Spain: Madrid, Arroyo de la } \\
\text { Fuentecilla (La Hiruela), } \\
23 \text { Apr. 2017. Leg: A. Gonçalves }\end{array}$ & - & $\mathrm{X}$ & $\mathrm{X}$ & $\mathrm{X}$ & $\mathrm{X}$ & $\mathrm{X}$ & $\mathrm{X}$ \\
\hline $\begin{array}{l}\text { Tachydromia } \\
\text { iberica }\end{array}$ & AR08 & $\begin{array}{l}\text { Portugal: Porto de Mós, Arrimal, } \\
11 \text { Mar. } 2017 . \\
\text { Leg: A. Gonçalves \& F. Barros }\end{array}$ & - & $\mathrm{X}$ & $\mathrm{X}$ & $\mathrm{X}$ & $\mathrm{X}$ & $\mathrm{X}$ & $\mathrm{X}$ \\
\hline $\begin{array}{l}\text { Tachydromia } \\
\text { iberica }\end{array}$ & AR09 & $\begin{array}{l}\text { Spain: Badajoz, Tentudía, } \\
3 \text { Apr. } 2015 \text {. } \\
\text { Leg: A. Gonçalves \& R. Andrade }\end{array}$ & - & $\mathrm{X}$ & $\mathrm{X}$ & $\mathrm{X}$ & $\mathrm{X}$ & $\mathrm{X}$ & $\mathrm{X}$ \\
\hline $\begin{array}{l}\text { Tachydromia } \\
\text { apterygon }\end{array}$ & AR10 & $\begin{array}{l}\text { Italy: Frosinone, San Donato Val } \\
\text { di Comino, 26 Jun. } 2017 . \\
\text { Leg: A. Gonçalves \& R. Andrade }\end{array}$ & - & $X$ & $\mathrm{X}$ & - & - & $X$ & $X$ \\
\hline $\begin{array}{l}\text { Empis } \\
\text { tessellata }\end{array}$ & AR11 & $\begin{array}{l}\text { Portugal: Lisboa, Monsanto, } \\
1 \text { Mar. } 2017 . \\
\text { Leg: A. Gonçalves \& S. Martins }\end{array}$ & - & $X$ & $X$ & $\mathrm{X}$ & $X$ & $X$ & - \\
\hline $\begin{array}{l}\text { Hybos } \\
\text { femoratus }\end{array}$ & AR12 & $\begin{array}{l}\text { Netherlands. } \\
\text { Leg. Ruud van der Weele }\end{array}$ & - & $\mathrm{X}$ & $\mathrm{X}$ & $X$ & $\mathrm{X}$ & $X$ & - \\
\hline $\begin{array}{l}\text { Drapetis } \\
\text { ephippiata }\end{array}$ & AR13 & $\begin{array}{l}\text { Netherlands. } \\
\text { Leg. Ruud van der Weele }\end{array}$ & - & $\mathrm{X}$ & $\mathrm{X}$ & $\mathrm{X}$ & $\mathrm{X}$ & - & $\mathrm{X}$ \\
\hline Stilpon sp. & AR14 & $\begin{array}{l}\text { Portugal: Aveiro, Salreu. } \\
\text { Leg. R. Andrade }\end{array}$ & - & $X$ & $\mathrm{X}$ & $\mathrm{X}$ & $X$ & $\mathrm{X}$ & - \\
\hline $\begin{array}{l}\text { Symballophthalmus } \\
\text { fuscitarsis }\end{array}$ & AR15 & $\begin{array}{l}\text { Belgium. } \\
\text { Leg. P. Grootaert }\end{array}$ & - & $\mathrm{X}$ & $\mathrm{X}$ & $\mathrm{X}$ & - & $\mathrm{X}$ & $\mathrm{X}$ \\
\hline $\begin{array}{l}\text { Tachydromia } \\
\text { cantabrica } \text { sp. nov. }\end{array}$ & AR16 & $\begin{array}{l}\text { Spain: Palencia, Río Carrión, } \\
14 \text { May } 2014 . \\
\text { Leg: A. Gonçalves \& R. Andrade }\end{array}$ & - & $X$ & $\mathrm{X}$ & $\mathrm{X}$ & $\mathrm{X}$ & $\mathrm{X}$ & - \\
\hline $\begin{array}{l}\text { Tachydromia } \\
\text { pieltaini }\end{array}$ & AR17 & $\begin{array}{l}\text { Spain: Asturias, Cangas de Onís, } \\
9 \text { Apr. 2016. Leg: A. Gonçalves }\end{array}$ & - & $\mathrm{X}$ & $\mathrm{X}$ & $\mathrm{X}$ & $X$ & $\mathrm{X}$ & $\mathrm{X}$ \\
\hline $\begin{array}{l}\text { Tachydromia } \\
\text { connexa }\end{array}$ & AR18 & United Kindgom & - & $X$ & $X$ & $X$ & $X$ & $X$ & $\mathrm{X}$ \\
\hline $\begin{array}{l}\text { Tachydromia } \\
\text { arrogans }\end{array}$ & AR19 & $\begin{array}{l}\text { Belgium. } \\
\text { Leg. P. Grootaert }\end{array}$ & - & $X$ & $\mathrm{X}$ & $\mathrm{X}$ & $\mathrm{X}$ & $X$ & $\mathrm{X}$ \\
\hline $\begin{array}{l}\text { Tachydromia } \\
\text { umbrarum }\end{array}$ & AR20 & $\begin{array}{l}\text { Netherlands. } \\
\text { Leg. Ruud van der Weele }\end{array}$ & - & $X$ & $\mathrm{X}$ & $\mathrm{X}$ & $\mathrm{X}$ & $\mathrm{X}$ & $\mathrm{X}$ \\
\hline $\begin{array}{l}\text { Tachydromia } \\
\text { umbrarum }\end{array}$ & AR21 & $\begin{array}{l}\text { Netherlands. } \\
\text { Leg. Ruud van der Weele }\end{array}$ & - & $X$ & $\mathrm{X}$ & $\mathrm{X}$ & $X$ & $\mathrm{X}$ & $X$ \\
\hline $\begin{array}{l}\text { Oropezella } \\
\text { sphenoptera }\end{array}$ & AR22 & Norway & $\begin{array}{c}\text { ZFMK-TIS- } \\
2547243\end{array}$ & $\mathrm{X}$ & $X$ & $\mathrm{X}$ & - & - & - \\
\hline $\begin{array}{l}\text { Oedalea } \\
\text { hybotina }\end{array}$ & AR24 & Finland & $\begin{array}{l}\text { ZFMK-TIS- } \\
2580838\end{array}$ & $\mathrm{X}$ & $\mathrm{X}$ & $\mathrm{X}$ & - & - & - \\
\hline $\begin{array}{l}\text { Bicellaria } \\
\text { intermedia }\end{array}$ & AR25 & Finland & $\begin{array}{l}\text { ZFMK-TIS- } \\
2580874\end{array}$ & $\mathrm{X}$ & $\mathrm{X}$ & $\mathrm{X}$ & $\mathrm{X}$ & $\mathrm{X}$ & $\mathrm{X}$ \\
\hline $\begin{array}{l}\text { Platypalpus } \\
\text { pectoralis }\end{array}$ & AR26 & Finland & $\begin{array}{l}\text { ZFMK-TIS- } \\
2580880\end{array}$ & $\mathrm{X}$ & $\mathrm{X}$ & $\mathrm{X}$ & $X$ & $\mathrm{X}$ & $\mathrm{X}$ \\
\hline $\begin{array}{l}\text { Tachypeza } \\
\text { truncorum }\end{array}$ & AR28 & Finland & $\begin{array}{l}\text { ZFMK-TIS- } \\
2586890\end{array}$ & $\mathrm{X}$ & $X$ & $\mathrm{X}$ & - & - & - \\
\hline $\begin{array}{l}\text { Trichina } \\
\text { clavipes }\end{array}$ & AR29 & Germany & $\begin{array}{c}\text { ZFMK-TIS- } \\
2593538\end{array}$ & $\mathrm{X}$ & $\mathrm{X}$ & $\mathrm{X}$ & - & - & $\mathrm{X}$ \\
\hline
\end{tabular}


Table 1 (continued).

\begin{tabular}{|c|c|c|c|c|c|c|c|c|c|}
\hline Species & $\begin{array}{l}\text { DNA voucher } \\
\text { ZMFK } \\
\end{array}$ & Label information & $\begin{array}{c}\text { GBOL catalogue } \\
\text { number }\end{array}$ & COI-5', & COI-3, & $28 S$ & AATS & $12 S$ & PGD \\
\hline $\begin{array}{l}\text { Tachydromia } \\
\text { terricola }\end{array}$ & AR30 & Finland & $\begin{array}{c}\text { ZFMK-TIS- } \\
2593583\end{array}$ & $\mathrm{X}$ & $\mathrm{X}$ & $\mathrm{X}$ & $\mathrm{X}$ & $\mathrm{X}$ & $X$ \\
\hline $\begin{array}{l}\text { Tachypeza } \\
\text { nubila }\end{array}$ & AR31 & $\begin{array}{l}\text { Netherlands. } \\
\text { Leg. Ruud van der Weele }\end{array}$ & - & $\mathrm{X}$ & $\mathrm{X}$ & $\mathrm{X}$ & - & $\mathrm{X}$ & - \\
\hline $\begin{array}{l}\text { Trichina } \\
\text { bilobata }\end{array}$ & AR32 & Germany & $\begin{array}{c}\text { ZFMK-TIS- } \\
2513222\end{array}$ & $X$ & $\mathrm{X}$ & $\mathrm{X}$ & $\mathrm{X}$ & $X$ & $X$ \\
\hline $\begin{array}{l}\text { Platypalpus } \\
\text { pseudofluvipes }\end{array}$ & AR33 & Finland & $\begin{array}{c}\text { ZFMK-TIS- } \\
2593700\end{array}$ & $\mathrm{X}$ & X & X & X & $\mathrm{X}$ & $X$ \\
\hline $\begin{array}{l}\text { Bicellaria } \\
\text { sulcata }\end{array}$ & AR34 & Germany & $\begin{array}{c}\text { ZFMK-TIS- } \\
2601004\end{array}$ & $\mathrm{X}$ & $\mathrm{X}$ & $\mathrm{X}$ & $\mathrm{X}$ & - & - \\
\hline $\begin{array}{l}\text { Oedalea } \\
\text { zetterstedti }\end{array}$ & AR35 & Germany & $\begin{array}{l}\text { ZFMK-TIS- } \\
2595873\end{array}$ & $\mathrm{X}$ & $\mathrm{X}$ & $\mathrm{X}$ & - & $\mathrm{X}$ & $\mathrm{X}$ \\
\hline $\begin{array}{l}\text { Tachypeza } \\
\text { truncorum }\end{array}$ & AR36 & Finland & $\begin{array}{c}\text { ZFMK-TIS- } \\
2586890\end{array}$ & $\mathrm{X}$ & $\mathrm{X}$ & $\mathrm{X}$ & - & - & $\mathrm{X}$ \\
\hline $\begin{array}{l}\text { Crossopalpus } \\
\text { sp. }\end{array}$ & AR37 & $\begin{array}{l}\text { Portugal: Aveiro, Salreu. Leg. } \\
\text { R. Andrade }\end{array}$ & - & $\mathrm{X}$ & $\mathrm{X}$ & $\mathrm{X}$ & $\mathrm{X}$ & - & $\mathrm{X}$ \\
\hline
\end{tabular}

Table 2. Primers used for amplifying and sequencing the molecular markers.

\begin{tabular}{|c|c|c|c|}
\hline Gene & Primer's name & Sequence & Reference \\
\hline COI-5 & LCO-1490 & GGTCAACAAATCATAAAGATATTG & Folmer et al. 1994 \\
\hline COI-5 & HCO-2198 & TAAACTTCAGGGTGACCAAAAAATCA & Folmer et al. 1994 \\
\hline COI-3' & COI-Dipt-283F & CARCAYYTATTYTGATTTTTTGG & Gibson et al. 2011 \\
\hline COI-3' & TLS-N-3014 (Pat) & TCCAATGCACTAATCTGCCATATTA & Simon et al. 1994 \\
\hline PGD & PGD-2F & ATHGARTAYGGNGAYATGCA & Regier 2008 \\
\hline PGD & PGD-3R & GTRTGNGCNCCRAARTARTC & Bertone et al. 2008 \\
\hline $28 \mathrm{~S}$ & $28 \mathrm{~s}-\mathrm{D} 1 \mathrm{Ft}$ & TGTAAAACGACGGCCAGTCCCCCTGAATTTAAGCATAT & Jemu 2011 \\
\hline $28 \mathrm{~S}$ & $28 \mathrm{~s}-\mathrm{D} 2 \mathrm{Rt}$ & CAGGAAACAGCTATGACGTTAGACTCCTTGGTCCGTG & Jemu 2011 \\
\hline $12 \mathrm{~S}$ & $12 \mathrm{~S}$ bi & AAGAGCGACGGGCGATGTGT & Simon et al. 1994 \\
\hline $12 \mathrm{~S}$ & $12 \mathrm{~S}$ ai & AAACTAGGATTAGATACCCTATTAT & Simon et al. 1994 \\
\hline AATS & AATS-1F40 & GNATGAAYCARTTYAARCCNAT & Su et al. 2008 \\
\hline AATS & AATS-1R244 & CATNCCRCARTCNATRTGYTT & Su et al. 2008 \\
\hline
\end{tabular}

\section{DNA extraction and sequencing}

Entire specimens, ethanol preserved and stored at $-20^{\circ} \mathrm{C}$, were used for DNA extraction. Extractions were carried out on complete specimens using the Dneasy Blood \& Tissue Kit (Qiagen, Valencia, CA, USA) to extract total nucleic acids following the manufacturer's instructions; samples were resuspended in 50-100 $\mu 1$ ultra-pure water instead of in the supplied elution buffer. Entire specimens were preserved and labelled as DNA voucher specimens for the purpose of morphological studies and deposited in ZFMK. The Qiagen Multiplex PCR Kit (Qiagen, Valencia, CA, USA) was used to carry out the PCRs. PCRs $(20 \mu \mathrm{l}$ ) included $2.5 \mu \mathrm{l}$ DNA extract, $1.6 \mu \mathrm{l}$ of each primer (at $10 \mathrm{pmol} / \mu \mathrm{l}), 2 \mu \mathrm{l}$ of Q-solution, $10 \mu 1$ of Qiagen Multiplex-Mix and $2.3 \mu$ of ultra-pure water. PCR amplifications were carried out with a Biometra PCR Thermal Cycler. PCR 'touchdown' programs are listed in Table 3, primers used for amplifying and sequencing the molecular markers are listed in Table 4. Amplified DNA was visualized on 1.5\% agarose gels for inspection of amplified products. PCR products were cleaned up using the commercially available QIAquick PCR Purification Kit (Qiagen, Valencia, CA, USA). Bi-directional Sanger sequencing reactions were carried out by Macrogen Inc. using the same primer pairs as those used for PCR reaction. 
Table 3. Detailed PCR protocols for each molecular marker.

\begin{tabular}{|c|c|c|c|}
\hline \multicolumn{4}{|c|}{ Reactions of $20 \mu \mathrm{l}$} \\
\hline $\mathrm{H}_{2} \mathrm{O}$ & 2.3 & & \\
\hline Q-Solution & 2 & & \\
\hline Qiagen Multiplex-Mix & 10 & & \\
\hline Primer A (10 pmol/ $\mu \mathrm{l})$ & 1.6 & & \\
\hline Primer B (10 pmol/ $/ \mu \mathrm{l})$ & 1.6 & & \\
\hline DNA & 2.5 & & \\
\hline \multicolumn{4}{|c|}{$\mathrm{COI}$} \\
\hline PCR protocol & Temperature $\left({ }^{\circ} \mathbf{C}\right)$ & Time (minutes) & Cycles \\
\hline Initial step & 95 & $15: 00$ & \\
\hline Denaturation & 94 & $00: 35$ & 25 \\
\hline Annealing & 55 & $01: 30$ & 25 \\
\hline Elongation & 72 & $01: 30$ & 25 \\
\hline Final Elongation & 72 & $10: 00$ & \\
\hline Cooling & 10 & $\infty$ & \\
\hline \multicolumn{4}{|c|}{ PGD } \\
\hline PCR protocol & Temperature $\left({ }^{\circ} \mathbf{C}\right)$ & Time (minutes) & Cycles \\
\hline Initial step & 95 & $15: 00$ & \\
\hline Denaturation & 95 & $00: 30$ & 36 \\
\hline Annealing & 50 & 01:00 & 36 \\
\hline Elongation & 72 & 01:00 & 36 \\
\hline Final Elongation & 72 & $10: 00$ & \\
\hline Cooling & 10 & $\infty$ & \\
\hline \multicolumn{4}{|c|}{$28 S$} \\
\hline PCR protocol & Temperature $\left({ }^{\circ} \mathrm{C}\right)$ & Time (minutes) & Cycles \\
\hline Initial step & 95 & $15: 00$ & \\
\hline Denaturation & 94 & $00: 35$ & 40 \\
\hline Annealing & 60 & $01: 30$ & 40 \\
\hline Elongation & 72 & $01: 30$ & 40 \\
\hline Final Elongation & 72 & $10: 00$ & \\
\hline Cooling & 10 & $\infty$ & \\
\hline \multicolumn{4}{|c|}{ AATS } \\
\hline PCR protocol & Temperature $\left({ }^{\circ} \mathrm{C}\right)$ & Time (minutes) & Cycles \\
\hline Initial step & 95 & $15: 00$ & \\
\hline Denaturation & 95 & $00: 30$ & 38 \\
\hline Annealing & 50 & 01:00 & 38 \\
\hline Elongation & 72 & 01:00 & 38 \\
\hline Final Elongation & 72 & $10: 00$ & \\
\hline Cooling & 10 & $\infty$ & \\
\hline \multicolumn{4}{|c|}{$12 S$} \\
\hline PCR protocol & Temperature $\left({ }^{\circ} \mathbf{C}\right)$ & Time (minutes) & Cycles \\
\hline Initial step & 94 & $01: 30$ & \\
\hline Denaturation & 94 & $00: 45$ & 38 \\
\hline Annealing & 50 & 01:00 & 38 \\
\hline Elongation & 74 & $02: 00$ & 38 \\
\hline Final Elongation & 74 & $05: 00$ & \\
\hline Cooling & 10 & $\infty$ & \\
\hline
\end{tabular}


Table 4. Selected evolutionary model to best fit each data partition using jModelTest ver. 2.1.5 under the Akaike Information Criterion.

\begin{tabular}{cccc}
\hline Genetic marker & \multicolumn{3}{c}{ Selected evolutionary model } \\
\hline $12 \mathrm{~S}$ & $\mathrm{TIM} 3+\mathrm{G}$ & \\
\cline { 2 - 3 } $28 \mathrm{~S}$ & trimmed & non-trimmed & \\
\cline { 2 - 3 } & $\mathrm{GTR}+\mathrm{I}+\mathrm{G}$ & $\mathrm{TVM}+\mathrm{I}+\mathrm{G}$ & \\
\cline { 2 - 3 } & $\mathbf{1}^{\text {st }}$ codon position & $\mathbf{2}^{\text {nd }}$ codon position & $\mathbf{3}^{\text {rd }}$ codon position \\
\cline { 2 - 3 } $\mathrm{COI}$ & $\mathrm{TIM} 2+\mathrm{I}+\mathrm{G}$ & $\mathrm{TVM}+\mathrm{I}+\mathrm{G}$ & $\mathrm{TIM} 2+\mathrm{G}$ \\
$\mathrm{AATS}$ & $\mathrm{TPM} 3 \mathrm{uf}+\mathrm{I}+\mathrm{G}$ & $\mathrm{GTR}+\mathrm{I}$ & $\mathrm{TVM}+\mathrm{I}$ \\
PGD & $\mathrm{GTR}+\mathrm{G}$ & $\mathrm{GTR}+\mathrm{I}$ & $\mathrm{TIM} 2+\mathrm{I}+\mathrm{G}$ \\
\hline
\end{tabular}

\section{Sequence alignment}

The sequences were edited for base-calling errors and assembled using Geneious R7 (ver. 7.1.3, Biomatters Ltd). To detect contamination, sequences were compared with known sequences of relatives as well as the GenBank database using nBLAST (NCBI Resource Coordinators 2016). The alignment of the protein-coding COI gene was done manually, and it was not necessary to include gaps in this alignment. The genes 12S, AATS and PDG were aligned by multiple alignment using fast Fourier transform (MAFFT) program (Katoh et al. 2005, 2009) ver. 7, which implements iterative refinement methods (Katoh \& Standley 2013). The E-INS-i algorithm was selected for 12S rRNa gene as it is optimized for small-scale alignments and is recommended for sequences with multiple conserved domains and long gaps (Katoh et al. 2009). For the potein-coding genes, the algorithm G-INS-i was used and the resulted alignment, then, checked using the aminoacid translation. The AATS sequences contained a gappy area with some small alignable regions at the beginning of the 5 ' end. Thus, the first sequenced 206 nucleotides, most likely an intron, were deleted. The alignment of $28 \mathrm{~S}$ gene was done using its secondary structure, as explained by Kjer (1995) and Kjer et al. (2009). This is the first time that the secondary structure of the 28S rRNA gene is used for the Hybotidae. Two versions of the $28 \mathrm{~S}$ alignment were produced in order to explore the influence of the Regions of expansion and contraction (RECs) and the Regions of slipped-strand compensation (RSCs) in the inferred topology. The REC and RSC regions, which could not be unambiguously aligned, were kept in one version of the alignment (non-trimmed) and deleted in the other version (trimmed).

\section{Sequence analysis}

Uncorrected pair-wise evolutionary distance among the Iberian ant-like species (11 nucleotide sequences belonging to nine taxa) was determined by using the p-distance substitution model in the software program MEGA7 (Kumar et al. 2016) (Table 5).

\section{Phylogenetic analyses}

For the combined dataset, two different phylogenetic analyses using maximum likelihood (ML) and Bayesian inference (BI) were performed. For both analyses, the molecular data set was divided into 11 partitions: first, second and third codon positions of COI, AATS and PGD, and the entire 28S and 12S genes. The best choice of model was determined for each partition using jModelTest ver. 2.1.5 (Darriba et al. 2012) under the Akaike Information Criterion (AIC), as recommended by Posada \& Buckley (2004), and the data was analysed under the recommended models (see Table 4).

ML analyses were performed using the Genetic Algorithm for Rapid Likelihood Inference, Garli ver. 2.01 (Zwickl 2006). Forty-six independent runs (46 different runs with the command searchreps $=1$ ) were conducted using the scorethreshforterm $=0.05$ and significanttopochange $=0.001$ settings and using the automated stopping criterion, terminating the search when the $\ln$ score remained constant for 
Table 5. Mean sequence divergence (uncorrected p-distances) of COI, between pairs of species of the Iberian ant-like Tachydromia Meigen, 1803 (calculated in MEGA7). Standard error estimates are shown above the diagonal.

\begin{tabular}{llccccccccccc}
\hline & $\mathbf{1}$ & $\mathbf{2}$ & $\mathbf{3}$ & $\mathbf{4}$ & $\mathbf{5}$ & $\mathbf{6}$ & $\mathbf{7}$ & $\mathbf{8}$ & $\mathbf{9}$ & $\mathbf{1 0}$ & $\mathbf{1 1}$ \\
\hline 1 & Tachydromia ebejeri sp. nov. & & 0.01 & 0.01 & 0.01 & 0.01 & 0.01 & 0.01 & 0.01 & 0.01 & 0.01 & 0.01 \\
2 & Tachydromia stenoptera sp. nov. & 0.10 & & 0.01 & 0.01 & 0.01 & 0.01 & 0.01 & 0.01 & 0.01 & 0.01 & 0.01 \\
3 & Tachydromia nigrohirta sp. nov. & 0.10 & 0.09 & & 0.01 & 0.01 & 0.01 & 0.01 & 0.01 & 0.01 & 0.01 & 0.01 \\
4 & Tachydromia lusitanica & 0.10 & 0.09 & 0.08 & & 0.01 & 0.01 & 0.01 & 0.01 & 0.01 & 0.01 & 0.01 \\
5 & Tachydromia pandellei & 0.11 & 0.10 & 0.10 & 0.10 & & 0.01 & 0.01 & 0.01 & 0.01 & 0.01 & 0.01 \\
6 & Tachydromia semiaptera & 0.12 & 0.11 & 0.11 & 0.11 & 0.12 & & 0.01 & 0.01 & 0.01 & 0.01 & 0.01 \\
7 & Tachydromia iberica [Spain, Madrid] & 0.11 & 0.10 & 0.11 & 0.10 & 0.10 & 0.10 & & 0.00 & 0.01 & 0.01 & 0.01 \\
8 & Tachydromia iberica [Portugal, Leiria] & 0.10 & 0.09 & 0.10 & 0.09 & 0.10 & 0.09 & 0.04 & & 0.01 & 0.01 & 0.01 \\
9 & Tachydromia iberica [Spain, Huelva] & 0.10 & 0.10 & 0.10 & 0.10 & 0.10 & 0.10 & 0.05 & 0.05 & & 0.01 & 0.01 \\
10 & Tachydromia cantabrica sp. nov. & 0.10 & 0.08 & 0.09 & 0.09 & 0.11 & 0.11 & 0.10 & 0.10 & 0.10 & & 0.01 \\
11 & Tachydromia pieltaini & 0.11 & 0.10 & 0.10 & 0.09 & 0.10 & 0.12 & 0.10 & 0.10 & 0.11 & 0.10 & \\
\hline
\end{tabular}

50000 consecutive generations. Bootstrap support values (BS) were estimated from 1000 replicates using the same independent models in Garli.

A phylogenetic estimation using the Markov Chain Monte Carlo algorithm as implemented in MrBayes ver. 3.2.6 (Huelsenbeck \& Ronquist 2001; Ronquist \& Huelsenbeck 2003) was performed using a parallelized version of the software (XSEDE in CIPRES Science Gateway). Priors were applied with default values. Six runs, with four chains each (one 'cold' chain and three heated chains; temp $=0.2$ ), were performed simultaneously for 20000000 generations which were sufficient to bring the convergence (average standard deviation) to a value of $<0.003$, sampling trees every 2500 generations. The initial 2000 trees $(25 \%)$ were discarded as burn-in, and Bayesian posterior probabilities (PP) were calculated using a 50\% majority-rule consensus tree inferred from the data. Analytical runs were performed on CIPRES Science Gateway (Miller et al. 2010) and all trees were drawn with the aid of FigTree ver. 1.4.2 (Rambaut 2009) and Adobe Illustrator CC 19.2.1.

\section{Results}

\section{Sequence characteristics}

Aligned nucleotide lengths of gene fragments were of $1504 \mathrm{bp}$ for COI, $518 \mathrm{bp}$ for AATS, $382 \mathrm{bp}$ for 12S, $766 \mathrm{bp}$ for PGD, $838 \mathrm{bp}$ for non-trimmed $28 \mathrm{~S}$ and $791 \mathrm{bp}$ for trimmed 28S. The total datasets included 4008 nucleotide characters (non-trimmed 28S) and 3961 nucleotide characters (trimmed 28S). Of the 35 specimens included in the analysis, sequences were obtained from 35 individuals, representing the selected 31 taxa, for COI (100\% of the data), 19 for 12S (54\%), 33 for 28S (94\%), 23 for AATS (66\%) and 25 for PGD (71\%). Species of Tachydromia (i.e., ingroup) were overall successfully sequenced and the sequencing only failed regarding PGD in T. nigrohirta sp. nov. and in T. cantabrica sp. nov., AATS and $28 \mathrm{~S}$ in T. apterygon. Among the Iberian ant-like Tachydromia, the uncorrected pairwise sequence divergences ( $\mathrm{p}$ ) for the COI gene varied from $8 \%$ between $T$. lusitanica and T. nigrohirta sp. nov., to 12\% between $T$. semiaptera and T. pandellei, and between $T$. semiaptera and T. pieltaini. The COI p-distance at intraspecific (interpopulational) level regarding T. iberica varied from $4 \%$ (between Leiria and Madrid) to 5\% (between Huelva and Madrid, Huelva and Leiria). The obtained ATTS sequences of species of Platypalpus and Tachydromia (but only those not originally placed in the genera Pieltainia and Ariasella) have an insertion of three nucleotides close to the 3' end of the amplified region. A nexus file with the final alignment is provided as Supp. file 2 and Supp. file 3, and two additional text files are also given in Supp. file 4 and Supp. file 5, with the original structural alignment for 28S. 


\section{Reconstruction of phylogenetic relationships}

The ML tree, non-trimmed 28S version, with the best likelihood score $(\ln \mathrm{L}=29397.646621)$ is presented in Fig. 2. Although the taxonomic sampling was focused on the diversity and phylogenetic relationships within the Iberian flightless ant-like Tachydromia and their systematic position to the remaining Tachydromia, other tribes within Tachydromiinae were included in our analyses. Hence, we would like to comment on their inferred relationships.

The evolutionary relationships within the subfamily Tachydromiinae generally received strong support. This subfamily was recovered as monophyletic, with the tribe Symballophthalmini Sinclair \& Cumming, 2006 as a sister group to Drapetidini [(Drapetis ephippiata (Fallén, 1815) + Crossopalpus sp.) + Stilpon sp.)] and to Tachydromiini $(\mathrm{BS}=100 ; \mathrm{PP}=1)$. Symballophthalmini being recovered as a sister group to the remaining Tachydromiinae is in agreement with the inference made by Sinclair \& Cumming (2006) and differs from the results obtained by Wahlberg \& Johanson (2018), which placed Symballophthalmini as a sister group to Tachydromiini. The relationship between Drapetidini Collin, 1961 and Tachydromiini was resolved with a high posterior probability (0.97) and a low bootstrap value (71). The phylogenetic relationships between the genera of Tachydromiini were overall inferred with very high support and resolved as [Platypalpus Macquart + (Tachypeza Meigen, $1830+$ Tachydromia $)$.

Regarding the ingroup, Tachydromia was recovered paraphyletic with respect to the species originally assigned to former genera Ariasella and Pieltainia. The evolutionary relationships within the ingroup (Tachydromia + Ariasella + Pieltainia) depicted in our results are of a very well-supported grouping with many internal nodes with high to moderate support. The clade (Tachydromia connexa Meigen, $1822+$ Tachydromia terricola Zetterstedt, 1819) and representing the connexa and terricola species groups, respectively, was resolved as the sister clade to the group containing the remaining Tachydromia, including the Iberian species. Within these remaining Tachydromia (Tachydromia arrogans (Linnaeus, 1761) + Tachydromia umbrarum Haliday, 1833) representatives of the arrogans and annulimana species group was resolved as a sister clade to the flightless species with very high support values $(\mathrm{BS}=100$; $\mathrm{PP}=1$ ). Tachydromia apterygon was placed in the cluster containing all flightless species, which is supported by moderate values of bootstrap and high values of posterior probability $(\mathrm{BS}=88 ; \mathrm{PP}=1)$, indicating that it is more phylogenetically related to the arrogans than to the terricola species group. The Iberian flightless ant-like species are a well-supported group with internal nodes generally with high support and with short length branches. Tachydromia semiaptera, originally the type species of the former genus Ariasella, was recovered with a very high support $(\mathrm{BS}=97 ; \mathrm{PP}=1)$, being the sister taxon to the remaining Iberian species. Moreover, Tachydromia iberica, originally the type species of the monotypic genus Pieltainia, appears as being closer related to the remaining Iberian species, than Tachydromia semiaptera. Tachydromia iberica is represented by specimens obtained from its three main occurrence localities. While there is a significant geographic distance and small differences concerning the male terminalia morphology (see Figs 6-8), these populations are phylogenetically closely related, as can be denoted by the very short branch length. Tachydromia pandellei and T. pieltaini were recovered as sister species with a very high Bayesian posterior probability $(\mathrm{PP}=1)$ but only moderate bootstrap support values $(\mathrm{BS}=75)$. The previously undescribed species were placed in the same grouping (PP $=1 ; \mathrm{BS}=84)$, being closely related. Tachydromia nigrohirta sp. nov. and T. lusitanica were recovered as sister species ( $\mathrm{BS}=80 ; \mathrm{PP}=0.98)$. The most related species to the clade (T. nigrohirta sp. nov. + T. lusitanica) are T. cantabrica sp. nov. and T. ebejeri sp. nov.; however, the phylogenetic relationships between these taxa remain unclear due to the lack of statistical support. The phylogenetic position of T. stenoptera sp. nov. was recovered, with a high support $(\mathrm{BS}=84 ; \mathrm{PP}=1)$, as a sister taxon to [T. cantabrica sp. nov. + (T. ebejeri sp. nov. + (T. nigrohirta sp. nov. + T. lusitanica))].

The topology of the majority-rule consensus tree resulting from Bayesian inference agrees with the most likely tree regarding all taxa of Tachydromiinae. Additionally, and regarding the datasets with trimmed and non-trimmed 28S, both analyses (by ML and BI) inferred the same topology for the Tachydromiinae (Fig. 2; Supp. file 1: Fig. 2). The BI analysis of the trimmed dataset produced a tree with slight differences 


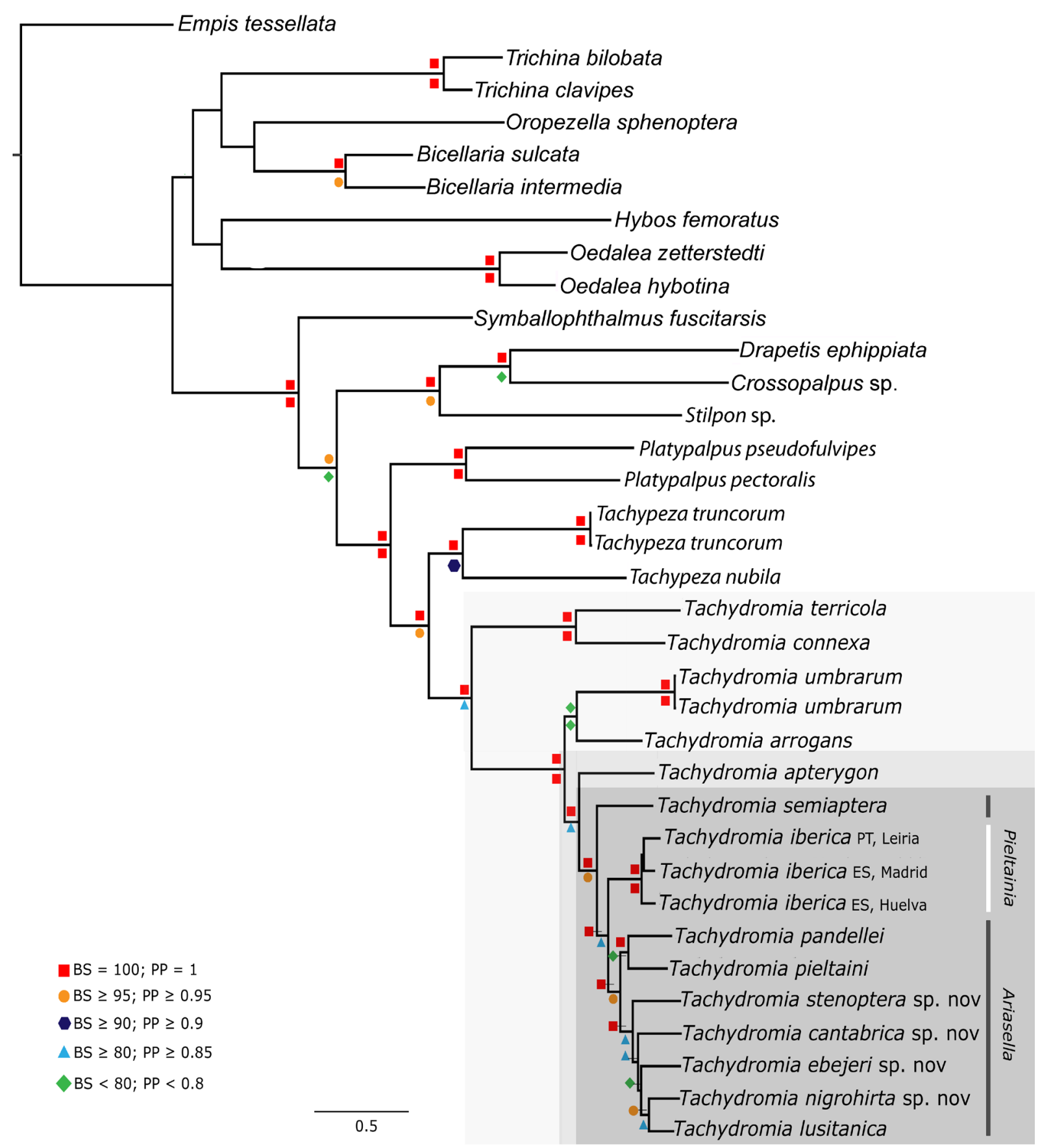

Fig. 2. Maximum-likelihood tree ( $\ln \mathrm{L}=-29397.646621$ ) based on the combined dataset (COI, nontrimmed 28S,12S, AATS and PGD) using Garli ver. 2.01.1067 and the structural alignment for 28S. Bootstrap support values (below) and Bayesian posterior probabilities (above) are depicted at the nodes (only $>50$ or $>0.5$, respectively). Abbreviations: $\mathrm{BS}=$ Bootstrap support values; $\mathrm{PP}=$ Bayesian posterior probabilities. A greyscale is used to highlight the ingroup, where the darkest shade of grey highlights the Iberian flightless ant-like species of Tachydromia Meigen, 1803, followed by a lighter shade which includes T. apterygon Plant \& Deeming, 2006, hence representing all the flightless species occurring in southern Europe and, finally, the lighter shade covers all Tachydromia analysed, including the macropterous species assigned to different species groups sensu Chvála (1970). The white bar indicates the species originally assigned to genus Pieltainia Arias, 1919, while the grey bars indicate the taxa originally assigned to genus different species-groups sensu Chvála (1970). 
in the PP support values, where the external nodes received less support and the interior nodes more support in comparison with the non-trimmed dataset. Considering the support values resulting from the ML approach, there is only a single notable case where the support value of the clade grouping all species of Tachydromia is much higher in the non-trimmed version (BS $=87$ in the non-trimmed; $\mathrm{BS}=$ 67 in the trimmed).

\title{
Taxonomy
}

\author{
Phylum Arthropoda Latreille, 1829 \\ Class Insecta Linnaeus, 1758 \\ Order Diptera Linnaeus, 1758 \\ Infraorder Muscomorpha Sharp, 1894 \\ Superfamily Empidoidea Latreille, 1804 \\ Family Hybotidae Meigen, 1820 \\ Subfamily Tachydromiinae Meigen, 1822 \\ Genus Tachydromia Meigen, 1803
}

\section{Key to the non-macropterous species of Tachydromia}

This key treats the 13 currently known non-macropterous species of Tachydromia, including the 10 antlike Tachydromia from the Iberian Peninsula and Italy.

1. Halteres present 2

- Halteres absent 4

2. Stenopterous wing, reduced to yellowish stub, in both sexes

Tachydromia rossica Shamshev, 1994 (Russian Far East)

- Brachypterous wing in both sexes

3. Wings $2 / 3$ as long as abdomen. Dorsocentral bristles short. Postpronotal lobe with minute, fine, pale bristles Tachydromia microptera (Loew, 1864) (Central Europe)

- Wings $3 / 5$ as long as abdomen. Dorsocentral bristles long. Postpronotal lobe with dark long bristles. Tachydromia schnitteri Stark, 1996 (Germany)

4. Females, without globous structure at abdominal apex (Figs 16J, 17B, H) 14

- Males, with globous structure (visible male terminalia) at abdominal apex (Figs 16I, 17A, C)....... 5

5. Wings completely absent. Tachydromia iberica (Arias 1919)

- Wings either present as vestiges (micropterous) or stalk-like process (stenopterous) (Figs 20A, C, E, G, 21A-B, D, F, 22)

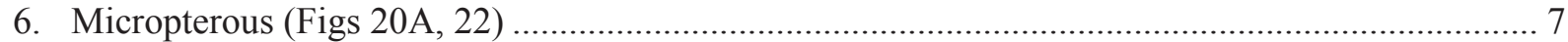

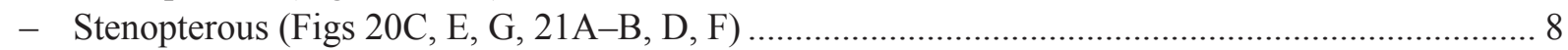

7. Palpi and antennae black; postpedicel lanceolate, ca 1.5 times as long as pedicel; wing is a single lobe, usually longer than wide, brownish, covered with microtrichia, at most with a single distinct seta (Fig. 20A)

Tachydromia ebejeri Gonçalves, Grootaert \& Andrade sp. nov.

- Palpi yellow; scape and pedicel yellow, postpedicel brown; postpedicel sub-conical, similar length as pedicel; wing roundish, bilobed, brownish, covered in microtrichia and bearing distinct setae (Fig. 22) . 
8. Antennae overall yellow and/or light brown, postpedicel roundish, approximately as long as pedicel......

- Antennae black; postpedicel sub-conical or lanceolate, longer than pedicel

9. Fore tibia black, stout and inflated; mid tibia with 1 projection at anteroventral apical surface (Fig. 19E-F). Tachydromia semiaptera (Gil Collado, 1923)

- Fore tibia yellow, as wide as mid and hind tibiae; mid tibia with 2 projections at apical surface (Fig. 19B-C).

10. Wing lobe with complex black and white pattern (Fig. 21B), antennae and legs overall yellow, mesonotum slightly convex

Tachydromia pieltaini (Gil Collado, 1936)

- Wing lobe white at basal half and black distally (Fig. 21A), antenna and legs yellow and brown, mesonotum convex and somewhat humped.....

Tachydromia pandellei (Séguy, 1941)

11. Wing with only slightly lobed distal apex (Fig. 21F); tergites bearing few and scattered setae; legs black, except for pale brown ventral and dorsal posterior surface of coxae, trochanter and basal ventral surface of femora and knees; right epandrial lamella convex, globose (Fig. 14A)

Tachydromia stenoptera Gonçalves, Grootaert \& Andrade sp. nov.

- Wing with distinctively lobed distal apex (Figs 20C, E, G); tergites totally covered by setae; legs with black and yellow / pale brown pattern; right epandrial lamella with a different general shape...

12. Distinct prescutellar setae absent, scutellum with two setae present medially; fore tibia with sparse ciliation of hair-like setae (shorter than maximum diameter of tibia) with slightly curved tips; left surstylus of terminalia with long setae on apical margin (Fig. 4C)

Tachydromia cantabrica Gonçalves, Grootaert \& Andrade sp. nov.

- Distinct prescutellar and scutellar setae present; fore tibia with dense ciliation of long hair-like setae with curved tips; left surstylus with setulae on apical margin (Figs 9C, 10C)......

13. Wing with bilobed distal apex, produced into long digitation on distal margin (Fig. 20E); legs black with the following segments yellowish-brown: coxa, trochanter, knee, anterior and ventral surfaces of fore and mid femora, base of fore and mid tibiae, basal $4 / 5$ surface of tarsomere 1 , basal surface, $2 / 3$ of mid and hind tarsomere 2 ..............Tachydromia lusitanica (Grootaert, Shamshev \& Andrade)

- Wing with lobed distal apex, without a distinct digitation on distal margin (Fig. 20G); legs black, excepting trochanters, knees and tarsomere 1 and 2 which are yellowish to brown Tachydromia nigrohirta Gonçalves, Grootaert \& Andrade sp. nov.

14. Wings completely absent.

Tachydromia iberica (Arias, 1919)

- Wings either present as vestiges (micropterous) or stalk-like process (stenopterous) (Figs 20B, D, F, H, 21C, E, G).

15. Antennae yellow and/or light brown, postpedicel roundish, approximately as long as pedicel ..... 16

- Antennae black; postpedicel sub-conical or lanceolate, longer than pedicel ................................... 19

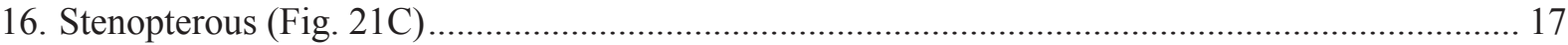

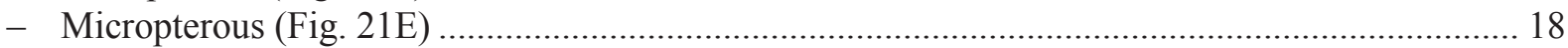

17. Antennae and legs overall yellow; scutellum bearing two setae; abdomen shiny black with grey microtrichia covering only last apical tergite and almost all sternites.

- Antennae and legs yellow and brown; scutellum lacking distinct setae; abdomen black, uniformly covered with grey microtrichia......

Tachydromia pandellei (Séguy, 1941) 
18. Palpi yellow in ground colour; wing bilobed, roundish, apical margin of posterior lobe bearing one long seta, anterior lobe bearing three shorter setae.

Tachydromia apterygon Plant \& Deeming, 2006

- Palpi black in-ground colour; wing as single lobe, roundish, bearing one long seta and one short seta on apical margin (Fig. 21E) Tachydromia semiaptera (Gil Collado, 1923)

19. Four prescutellar setae and four scutellar setae; wing as single lobe, usually longer than wide, at most with single distinct seta present (Fig. 20B); coxae, femora and most of tibia dark brown to black; trochanters, knee, anteroventral surface of tibia, distal $1 / 4$ of tarsomere 1 , distal half of tarsomere 2 and following tarsomeres, yellowish

Tachydromia ebejeri Gonçalves, Grootaert \& Andrade sp. nov.

- Different number of prescutellar and scutellar setae; wing bilobate, roundish, with distinct setae (Figs 20D, F, H, 21G)

20. Tergites with few and scattered setae, mostly present on posteromarginal surface and near spiracles; sternites with evenly distributed setae; legs almost completely black, excepting very small brown portions, specifically: ventral and dorsal posterior surfaces of coxae, trochanter, basal ventral surface of femora and knees....................Tachydromia stenoptera Gonçalves, Grootaert \& Andrade sp. nov.

- Tergites and sternites with evenly distributed setae; legs with different colour pattern of black and yellow to brown.

21. Postpronotal lobe bearing ca 4 setae laterally; wings bilobate, bearing one seta on apical margin of each lobe (Fig. 20D); legs black with following segments pale brown/yellowish: apical portion of coxae, trochanters, basal portion of mid and hind femora, distal apical surface of fore and mid femora, knees, basal $4 / 5$ surface of tarsomere 1 and basal $2 / 3$ surface of tarsomere 2 .....

Tachydromia cantabrica Gonçalves, Grootaert \& Andrade sp. nov.

- Postpronotal lobe bearing more than 4 setae laterally; wings bilobate, bearing more than two setae on both lobes combined (Fig. 20F, H); legs with a different colour pattern.....

22. Legs black, except for trochanters, knees and tarsomeres 1 and 2 yellowish to brown

Tachydromia nigrohirta Gonçalves, Grootaert \& Andrade sp. nov.

- Legs black with following segments yellowish-brown: coxa, trochanter, knee, anterior and ventral surface of fore and mid femora, base of fore and mid tibia, basal $4 / 5$ surface of tarsomere 1 , basal surface $2 / 3$ of mid and hind tarsomere 2 ....Tachydromia lusitanica (Grootaert, Shamshev \& Andrade, 2009)

\section{General diagnosis of the Iberian and Italian ant-like species of Tachydromia}

The Iberian and Italian ant-like Tachydromia species can be jointly characterized by lacking halteres and functional wings (apterous, micropterous or stenopterous). Considering their overall morphology (e.g., shape and colouration of palpus and pubescence of legs), it can be said that Iberian species are generally more related to the arrogans species group than to any other; however, various species differ from this group in having a shorter stylus 1.5 times as long as the antenna (T. semiaptera, T. pieltaini and T. pandellei) and/or for having male genitalia large and globular (T. stenoptera sp. nov.). Plant \& Deeming (2006) suggested that T. apterygon is more related to terricola group. They are quick and agile runners and often move their abdomens up and downwards, resembling ants or certain flightless parasitic wasps.

Tachydromia apterygon Plant \& Deeming, 2006

Figs 3, 16I-J, 19J, 22-24

Tachydromia apterygon Plant \& Deeming, 2006: 13 (male only). 


\section{Diagnosis}

Small (length $=2 \mathrm{~mm}$ ), slender, overall dark, with minute bilobed squamiform wings (Fig. 22) in both sexes and halteres absent. Frons, vertex and occiput largely covered by grey microtrichia; 1 pair of lateroclinate ocellars; 1 pair of proclinate verticals; palpi pale yellow, antennae with scape and pedicel yellow, postpedicel brown; proboscis shiny black; postpedicel sub-conical, similar length as of pedicel. Thorax black with portion of episternum densely covered with grey microtrichia. Legs with colour pattern of yellowish and dark brown to black; fore tibia with ciliation of short coarse setae. Mid tibia with anteroventral spur at apex, produced into short apical elongation, about as long as diameter of tibia at apex (Fig. 19J); spur with several distinct setae and, on distal half margin, a few short, stout, curved spinose setae. Abdomen black, covered with grey microtrichia and short setae, longer at hind margin of last sternite.

\section{Type material examined}

\section{Holotype}

ITALY 1 ô; Lazio, $10 \mathrm{~km}$ south of Forca d'Acero, on road to Sora; 1 Jul. 2005; J.C. Deeming leg.; NMWC.

\section{Additional material examined}

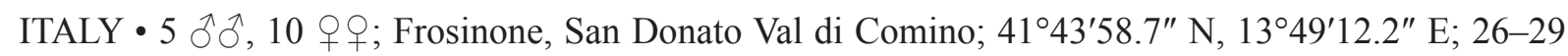

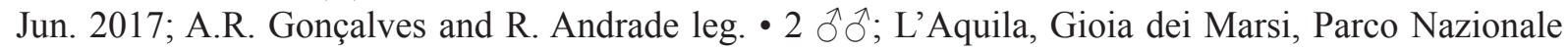

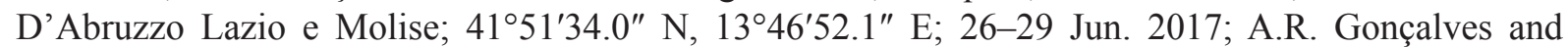

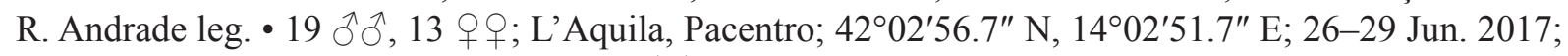
A.R. Gonçalves and R. Andrade leg. • $18 \partial^{\jmath} \partial^{\top}, 14$ q o ; Pescara, Sant'Eufemia a Maiella; $42^{\circ} 06^{\prime} 01.2^{\prime \prime}$ N,

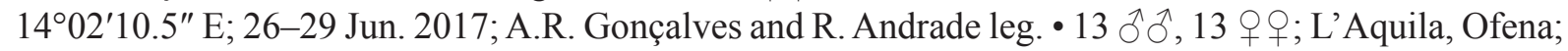

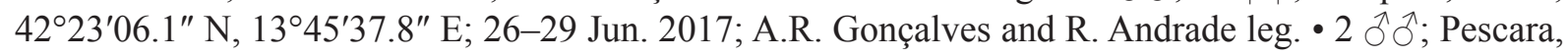

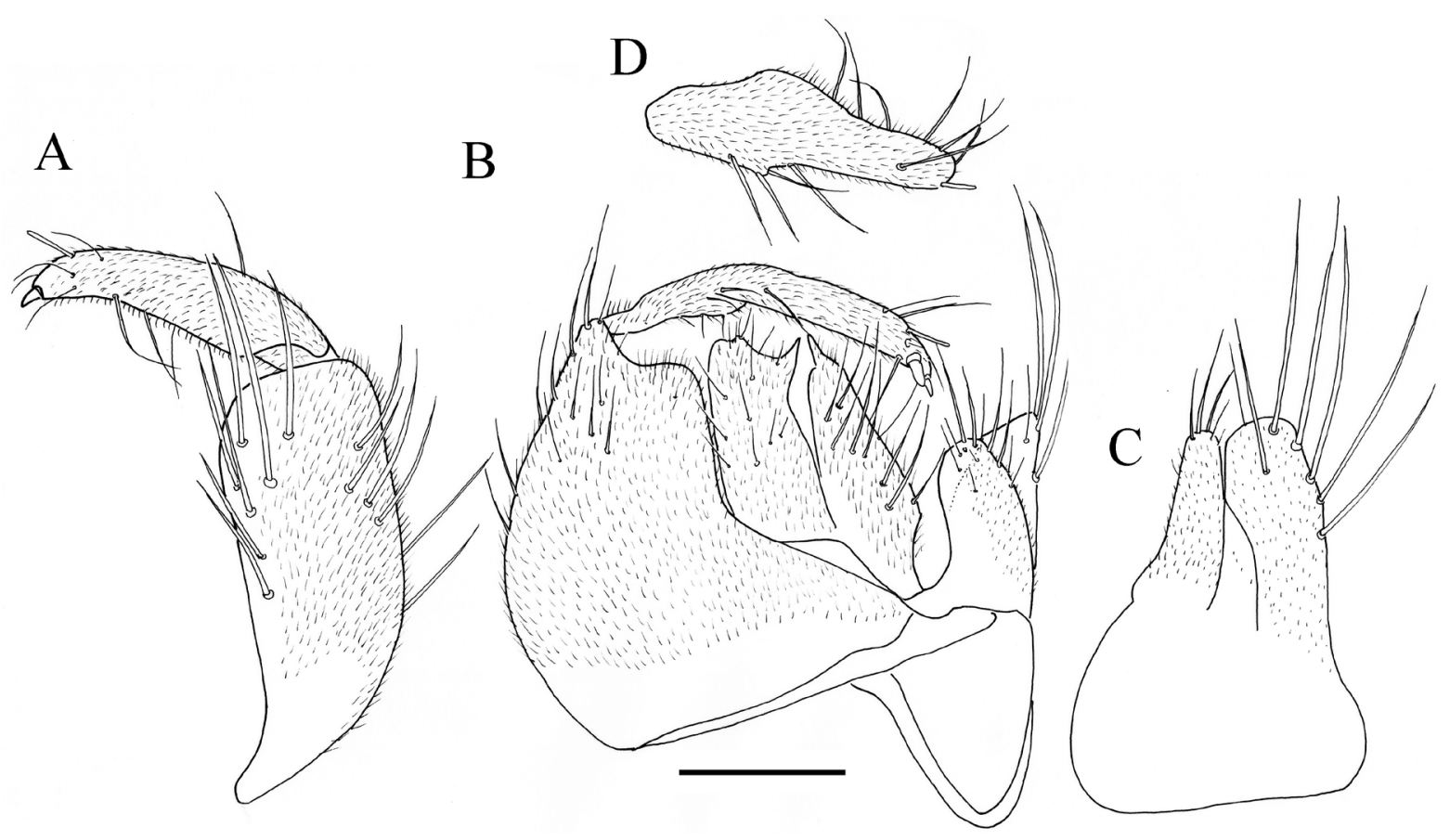

Fig. 3. Terminalia of Tachydromia apterygon Plant \& Deeming, 2006 from Italy, Lazio, Posta (RBINS). A. Right surstylus and right epandrial lamella. B. Epandrium with cerci. C. Left epandrial lamella and left surstylus. D. Right surstylus. Scale bar: $0.1 \mathrm{~mm}$. 
Farindola; 42 $23^{\prime} 45.7^{\prime \prime}$ N, 134'06.8" E; 26-29 Jun. 2017; A.R. Gonçalves and R. Andrade leg. •

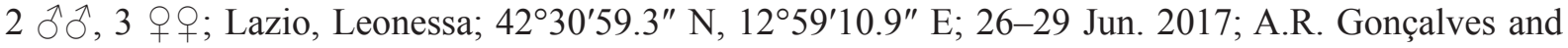
R. Andrade leg.; ZFMK • 4 $\widehat{\jmath}, 3$ 우 (all male terminalia studied, RBINS); Lazio, Posta; $42^{\circ} 31^{\prime} 51.2^{\prime \prime} \mathrm{N}$, 1303'37.4" E; 26-29 Jun. 2017; A.R. Gonçalves and R. Andrade leg.

\section{Description}

Female (previously undescribed)

Similar to male. Micropterous, wing round, brownish, bilobate, apical margin of posterior lobe bearing 1 long seta, anterior lobe bearing 3 shorter setae, lobes covered with grey microtrichia. Differs from male in following: legs mainly covered with microtrichia and regular rows of setae; spur on mid tibia absent; cercus pale brown with grey microtrichia and long setae; a few longer setae on apical sternites.

\section{Distribution and habitat}

Italy. Currently, this species is only known from the central Apennine Mountains (Fig. 23). It occurs on the edge of forests of Fagus sylvatica L. (Fig. 24), on the leaf litter and short herbaceous vegetation, where it can be abundant. It has also been found in mixed deciduous woodland at lower altitudes, inside the forest, on the leaf litter.

\section{Remarks}

Despite the sampling effort at the end of July, the species was not found at the mixed deciduous woodland type locality. However, it was still very abundant at higher altitudes. The type specimen was collected at the beginning of July, so by the end of the month, it may already be too hot and dry for this species to survive at lower altitudes.

Tachydromia cantabrica Gonçalves, Grootaert \& Andrade sp. nov. urn:1sid:zoobank.org:act:1F27952E-DD08-44E5-AF55-39019FD06488

Figs 1, 4, 15I-J, 18A-B, 19H, 20C-D

\section{Diagnosis}

Overall dark. Wing dimorphic: male stenopterous; wing with lobed distal apex, no veins distinguishable, dark brown for most part, with black and white lobe; female micropterous, wing bilobate, with 1 seta on each lobe. Palpi, proboscis and antennae black; postpedicel sub-conical, ca 1.5 times as long as pedicel. Legs with a colour pattern of yellowish and dark brown to black; male fore tibia with ciliation of long hairlike setae. Abdomen black, tergites and sternites with evenly distributed setae, covered with grey microtrichia. It shares similarities with $T$. nigrohirta sp. nov. and T. stenoptera sp. nov., but can be distinguished from these species by the darker leg colouration, lobed distal apex of male wing without any trace of apical digitation, sub-conical postpedicel, and male terminalia.

\section{Etymology}

This species is named after the Spanish Cantabrian mountain range, where it was found.

\section{Material examined}

\section{Holotype}

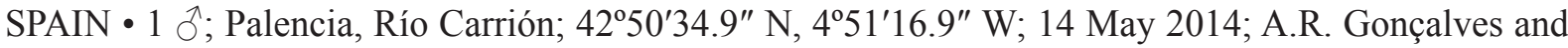
R. Andrade leg.; RBINS.

\section{Paratypes}

SPAIN • $4 \partial^{\lambda} \partial^{\lambda}, 2$ q 9 ; Palencia, Río Carrión; 4250’34.9” N, 451'16.9” W; 14 May 2014; A.R. Gonçalves and R. Andrade leg.; RBINS. 


\section{Additional material examined}

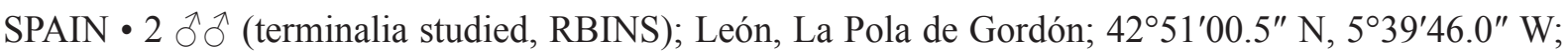
13-14 May 2014; A.R. Gonçalves and R. Andrade leg. • 1 ๆ (terminalia studied, RBINS); León, Boca de Huérgano 42 $56^{\prime} 27.3^{\prime \prime}$ N, 454'10.0" W; 13-14 May 2014; A.R. Gonçalves and R. Andrade leg.

\section{Description}

\section{Male}

MeAsurements. Body length: $2.1-2.3 \mathrm{~mm}(\mathrm{n}=3)$. Wing length: $0.8-0.9 \mathrm{~mm}(\mathrm{n}=3)$.

HEAD. Face and frons largely glabrous, shiny black; ocellar tubercle shiny anteriorly and finely pollinose posteriorly. 1 pair lateroclinate ocellars, same length as postpedicel, no posterior ocellars. 1 pair proclinate verticals, ca $1 / 4$ shorter than length of postpedicel, and numerous setae on occiput; no postocular ciliae present; mouth margin covered by grey microtrichia and with long setulae.

AnTENNA. Black, covered by grey microtrichia. Scape as long as wide; pedicel twice as long as wide, with apical circlet of black setae, ventrals longer; postpedicel sub-conical, ca 1.5 times as long as pedicel, with numerous pale setulae longer dorsally and apically; stylus almost twice as long as scape, pedicel and postpedicel combined.

Palpus. Elongate oval, about 3 times as long as wide. Black in ground colour with grey microtrichia, dorsally clothed in strong, long silvery-white and black setae, bearing one strong black sub-apical seta slightly shorter than palpus; less numerous setae present ventrally with distinct seta on ventral apex.

Proвоscis. Black, mostly glabrous, setae present ventrally, slightly larger than palpus.

THORAX. Elongated, overall black and largely shiny, with long setae black, short ones pale. Postpronotal lobe, episternum, mesopleuron and sternopleuron almost undifferentiated, scutellum short; notopleuron,

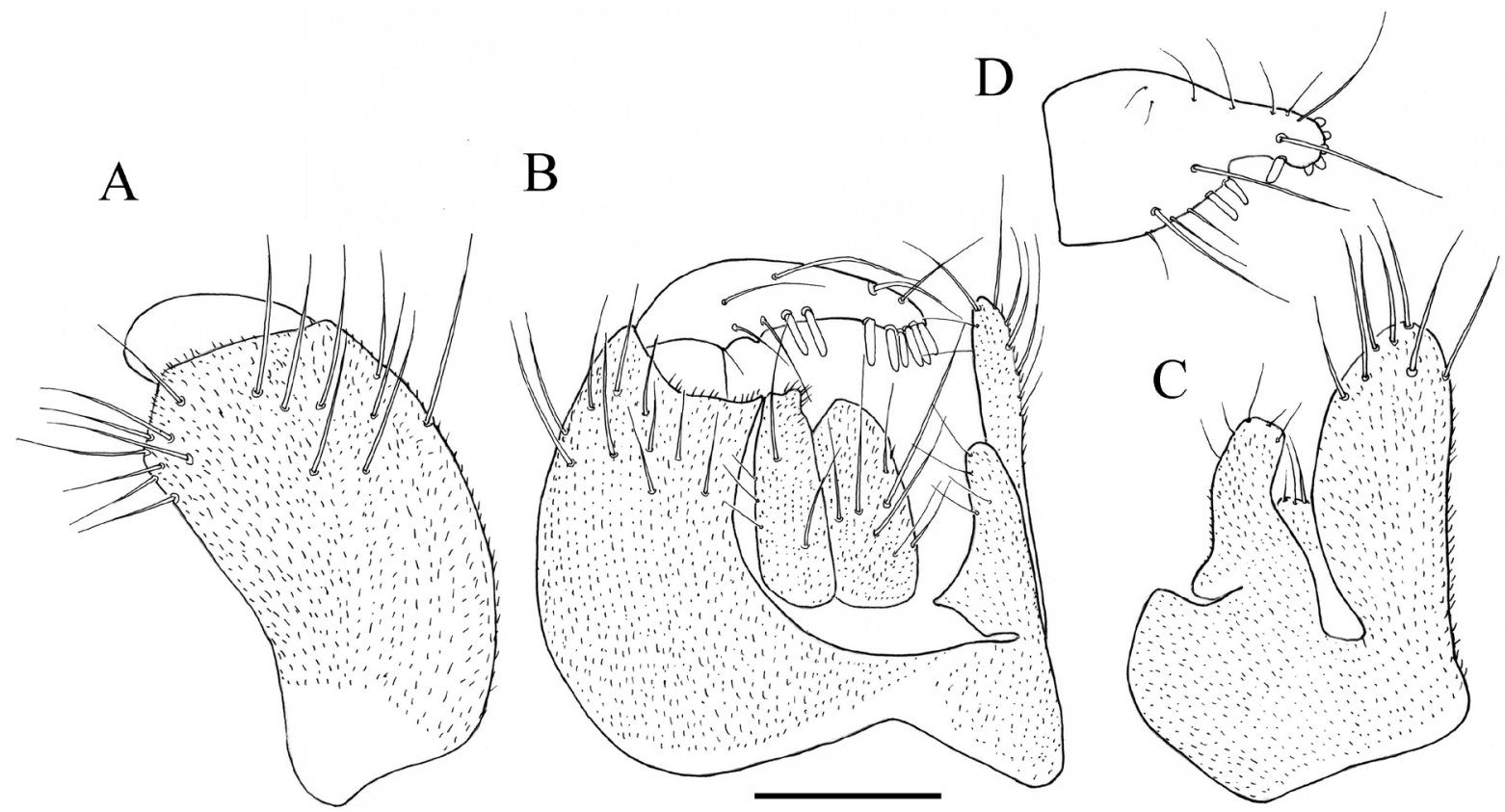

Fig. 4. Terminalia of Tachydromia cantabrica Gonçalves, Grootaert \& Andrade sp. nov., holotype (RBINS). A. Right surstylus and right epandrial lamella. B. Epandrium with cerci. C. Left epandrial lamella and left surstylus. D. Right surstylus. Scale bar: $0.1 \mathrm{~mm}$. 
anepisternum, katepimeron, meron and postscutellum well developed. Pleura black, overall glabrous with defined patches of grey microtrichia: prosternum and prothoracic episternum partially, but densely covered, appearing subtriangular in lateral view; katepimeron, meron, scutellum and upper part of the metathorax thinly covered. Postpronotal lobe bearing ca 4 setae laterally, no dorsocentrals, eight acrostichal setae, biseriate, of equal length; notopleuron with 1 strong, prominent, seta plus 2 small setae; 4 small, incurvated, prescutellar setae; scutellum bearing 2 strong, long setae medially; 1 pre-alar seta.

WING. Stenopterous. Lobed distal apex, suboval, with minute digitation. Stalk-like portion dark brown, distal $2 / 3$ of lobe black with basal $1 / 3$ and digitation translucid (appearing white under most light conditions) (Fig. 20C). No veins distinguishable. Uniformly covered in microtrichia.

Legs. Fore femur stout and inflated basally, mid femur less so and hind femur least. Black with the following pale brown/yellowish: basal portion of coxae, trochanters, basal portion of mid and hind femora, distal apical surface of fore and mid femora, knees, basal $4 / 5$ surface of tarsomere 1 and basal $2 / 3$ surface of tarsomere 2 . Legs mostly covered with regular rows of numerous black and pale setulae, except for coxae, trochanters and posteroventral surface of femora; anteroventral surface of coxae, femora (except most of ventral surface) and tibiae covered by grey microtrichia; coxae with several short, downward directed, dorsal anteroapical setae. Femora with a few distinct apical setae. Fore tibia bearing sparse ciliation of hair-like setae (shorter than maximum diameter of tibia) with slightly curved tips, and row of long, erect, setae present at its distal $1 \frac{1}{3}$ posterodorsal surface. Tarsomere 1 of fore tarsus with strong and long (twice tarsomere 1 width) setae; at posterior distal surface with row of distinct, short, black setae. Mid tibia with spur at anteroventral apex, with barely noticeable apical elongation, about as long as diameter of tibia at apex (Fig. 19H); spur has several distinct setae and, on distal half margin, five short, stout, curved, spinose setae.

ABDOMEN. Black, uniformly covered with grey microtrichia. Tergites and sternites with evenly distributed setae; apical sternites with long, distinct setae.

Terminalia (Fig. 4). Subglobular, mostly covered with grey microtrichia, dark brown. Right surstylus short with anterior margin produced into short slender projection, mostly glabrous, without microtrichia, bearing stronger setae mostly on dorsal margin, with several (ca 8) distinct denticles, most of which aggregated on distal apex. Right epandrial lamella with irregularly placed long setae, with patch of similar setae on lateral surface. Cerci of similar length, both with long setae of unequal length, enclosed in epandrial lamellae. Left epandrial lamella slightly shorter than left cercus, bilobed, with a few long setulae on apical margin. Left surstylus subrectangular with rounded apical margin, 3 times as long as wide, distinctively longer than cercus, densely covered with grey microtrichia with equally long setae on apical margin.

\section{Female}

Similar to male, except for following features: micropterous, with wings round, brownish, bilobate, bearing 1 seta on apical margin of each lobe, covered by grey microtrichia (Fig. 20D); legs covered with regular rows of setae; spur on mid tibia absent; cercus pale brown with grey microtrichia and setae; no longer setae on apical sternites.

\section{Distribution}

Spain. Currently only known from the Cantabrian Mountains. 
Tachydromia ebejeri Gonçalves, Grootaert \& Andrade sp. nov. urn:lsid:zoobank.org:act:1FF1B253-96ED-46A8-B8EB-1822B9789B2A

Figs 1, 5, 15E-F, 17E-F, 19D, 20A-B, 25

\section{Diagnosis}

Overall dark. Micropterous, with minute squamiform wings in both sexes. Palpi, proboscis and antennae black; postpedicel lanceolate, ca 1.5 times longer than pedicel. Legs with a colour pattern of yellowish and dark brown to black; fore tibia with ciliation of long hair-like setae. Abdomen black, covered with grey microtrichia and with distinct, strong, setae on posterior margin of first sternite. It shares general similarities with T. cantabrica sp. nov., T. stenoptera sp. nov. T. nigrohirta sp. nov. and T. lusitanica, from which it can be mainly distinguished by microptery in both sexes - while the males of the other species are stenopterous - and male terminalia.

\section{Etymology}

The species is named after the dipterologist Martin J. Ebejer for his contribution to the advancement of the knowledge on Portuguese Diptera.

\section{Material examined}

Holotype

PORTUGAL • 1 ơ; Marvão, Santa Maria de Marvão; 39²3'49.2" N, 7²1'51.4" W; 14 Mar. 2015; A.R. Gonçalves and R. Andrade leg.; RBINS.

Paratypes

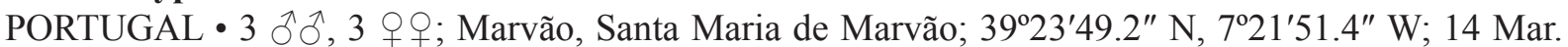
2015; A.R. Gonçalves and R. Andrade leg.; RBINS • 2 $\partial^{\lambda}, 2$ 우; same collection data as for precedcing; ZFMK.

\section{Additional material examined}

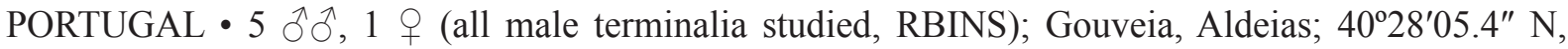
7³5'15.7" W; 25 Apr. 2013; A.R. Gonçalves and R. Andrade leg. • 3 ${ }^{\circ}$, 4 우 (all male terminalia studied, RBINS); Arganil, Benfeita (Mata da Margaraça); 40¹2'59.6" N, 755'12.5" W; 22 Feb. 2014;

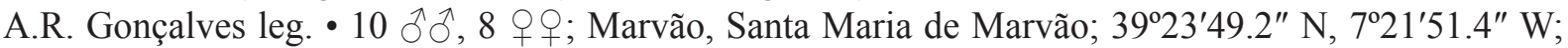
14 Mar. 2015; A.R. Gonçalves and R. Andrade leg. 4 ถิ $\widehat{\partial}, 10$ 우; Guarda, Gouveia, São Cosmado; 40²8'4.49" N, 7³5'25.18" W; 20 Apr. 2015; A.R. Gonçalves leg. • 1 ㅇ (terminalia studied, RBINS); Guarda, Seia, Alvoco da Serra; 40¹8'03.4" N, 7²1'22.6" W; Apr. 2015; A.R. Gonçalves leg. • 1 ○’, 2 우 (all male terminalia studied, RBINS); Guarda, Gouveia, Aldeias (Eiras); 40²8'26.5" N, 7³5'49.6" W;

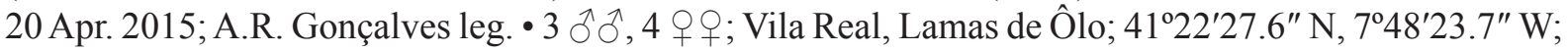

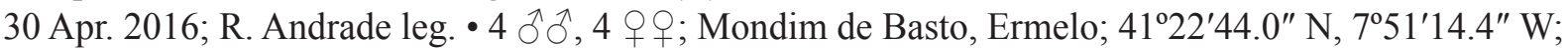
30 Apr. 2016; R. Andrade leg. 1 ô, 3 우; Castro Laboreiro; 42 $02^{\prime} 09.3^{\prime \prime} \mathrm{N}, 8^{\circ} 10^{\prime} 09.6^{\prime \prime} \mathrm{W} ; 29$ May 2016; R. Andrade leg. • 4 qo ; Viseu, Póvoa Dão; 40³3'03.9" N, 757'05.6" W; 18 Mar. 2017; J.

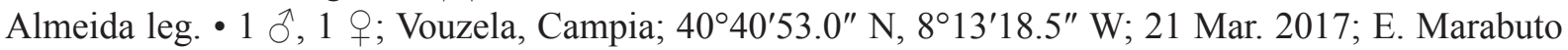

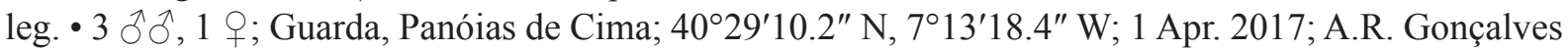

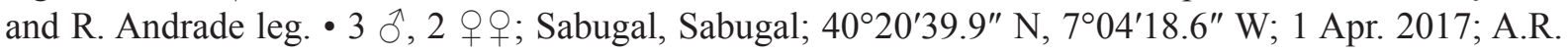

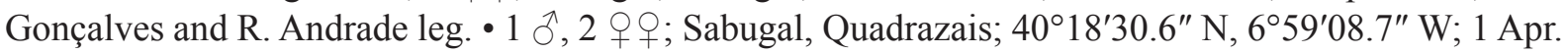

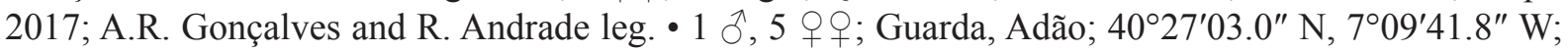

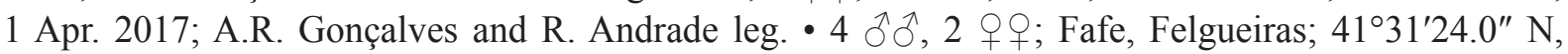

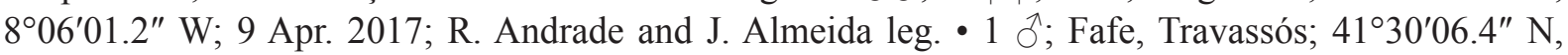

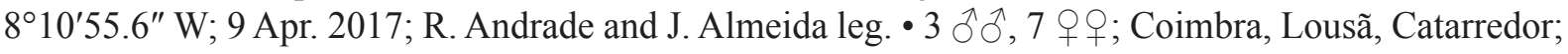
$40^{\circ} 04^{\prime} 20.9^{\prime \prime}$ N, 8¹3'04.2" W; 19 Apr. 2017; A.R. Gonçalves and D. Rodrigues leg. 


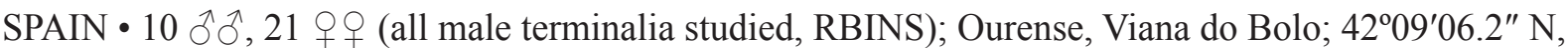
$7^{\circ} 07^{\prime} 12.3^{\prime \prime}$ W; 11 May 2014; A.R. Gonçalves and R. Andrade leg. • 3 우 (all male terminalia studied, RBINS); Ourense, O Bolo; 42 ${ }^{\circ} 15^{\prime} 03.2^{\prime \prime}$ N, $7^{\circ} 06^{\prime} 46.9^{\prime \prime}$ W; 11 May 2014; A.R. Gonçalves and R. Andrade

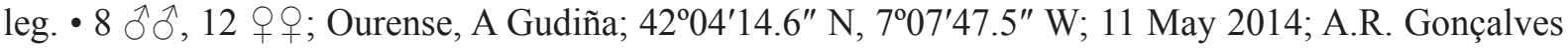

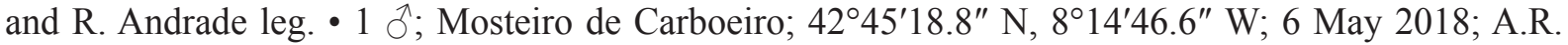

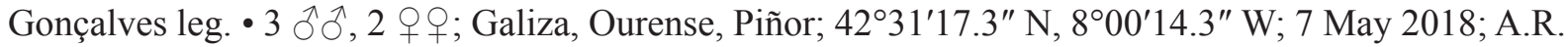
Gonçalves leg.

\section{Description}

Similar to Tachydromia cantabrica sp. nov. except for the following:

\section{Male}

MEasurements. Body length: 1.9-2.4 mm $(\mathrm{n}=5)$. Wing length: 0.05-0.16 mm $(\mathrm{n}=5)$.

HEAD. Lateroclinate ocellars $3 / 4$ as long as postpedicel. Proclinate verticals ca $1 / 2$ as long as postpedicel.

Antenna. Postpedicel lanceolate, ca 2 times as long as pedicel.

THORAX. Postpronotal with ca 6 setae laterally, 7 acrostichal setae; notopleuron with 1 strong, prominent, seta plus 4 small setae; scutellum with 4 setae medially, central pair long and thick, lateral thick but shorter.

WING (Fig. 20A). Micropterous, covered by grey microscopic setulae, no setae present.

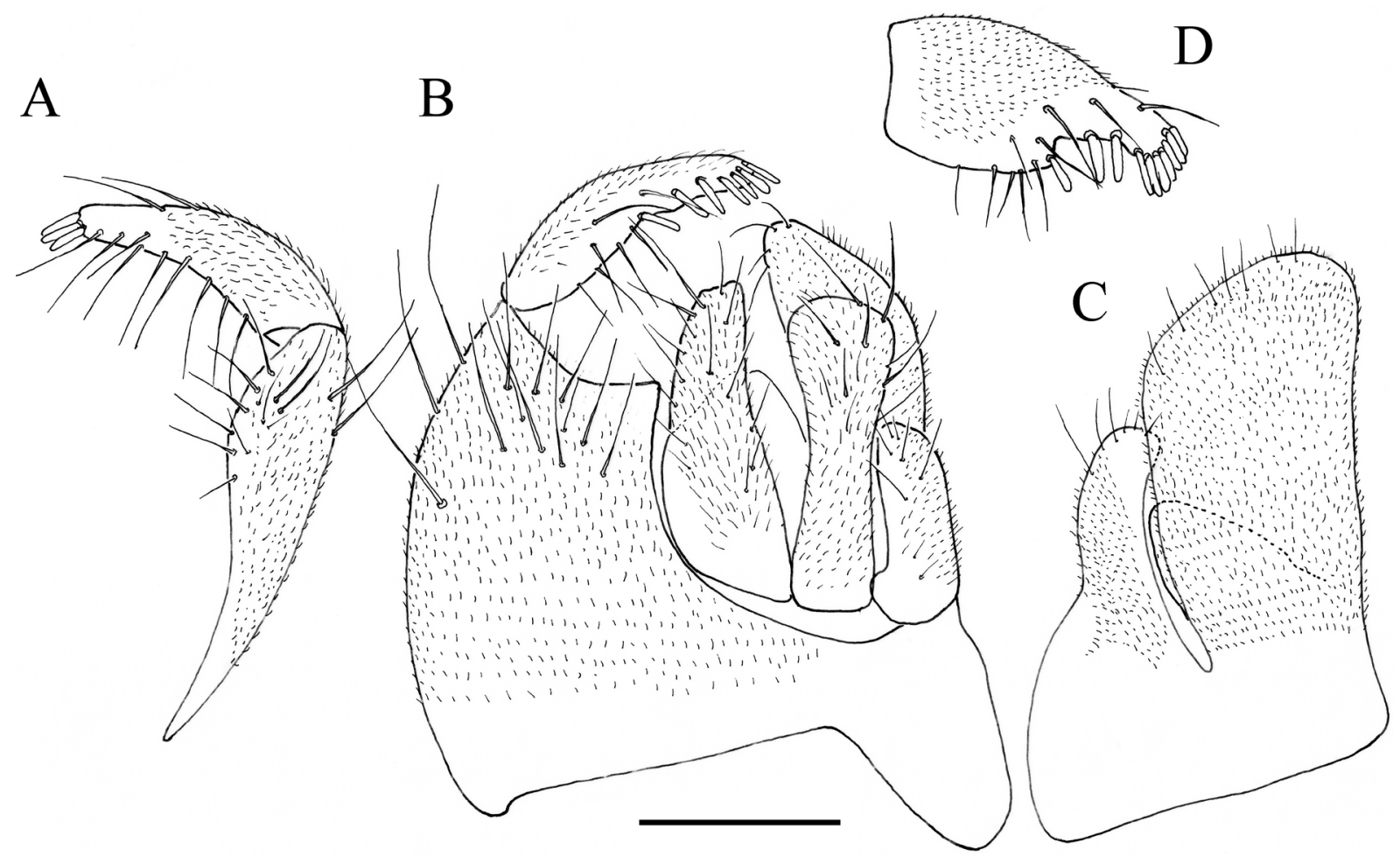

Fig. 5. Terminalia of the holotype of Tachydromia ebejeri Gonçalves, Grootaert \& Andrade sp. nov., holotype (RBINS). A. Right surstylus and right epandrial lamella. B. Epandrium with cerci. C. Left epandrial lamella and left surstylus. D. Right surstylus. Scale bar: $0.1 \mathrm{~mm}$. 
Legs. Coxae, femora and most of tibia dark brown to black; trochanters, knee, anteroventral surface of tibia, distal $1 / 4$ of tarsomere 1 , distal half of tarsomere 2 and following tarsomeres yellowish. Sparse ciliation of hair-like setae on fore tibia slightly longer than maximum diameter of tibia.

AвDOMEN. First tergite with differentiated, strong posteromarginal setae.

TERminalia (Fig. 5). Right surstylus covered with long setulae, without microtrichia, bearing stronger setae mostly on dorsal margin, with several (ca 10) distinct denticles, $2 / 3$ of which aggregated on distal apex. Right cerci with broad tip, left narrowing distally, both with long setae of unequal length on apical half, enclosed in epandrial lamellae. Left epandrial lamella $2 / 3$ as long as left cercus. Left surstylus 2 times as long as wide, longer than cerci, with short setae of equal length on apical margin.

\section{Female}

Similar to male, including being micropterous (Fig. 20B), except for following features: no distinctive hairs or setae on fore femur; spur on mid tibia absent; cercus pale brown with grey microtrichia and setae; no longer setae on apical sternites.

\section{Distribution}

Portugal and Spain. Mostly distributed in the northwestern Iberia (North and Central Portugal and Galicia), with just one locality south of the Tagus river (Santa Maria de Marvão).

Tachydromia iberica (Arias, 1919)

Figs 1, 6-8 16A-B, 18C-D

Pieltainia iberica Arias, 1919: 479 (male and female).

Tachydromia iberica Shamshev \& Grootaert 2018: 425 (comb. nov.).

\section{Diagnosis}

Predominantly dark and glabrous. Wings, or any traces of it, absent. Palpi, proboscis and antennae black. Postpedicel subconical, 2 times longer than pedicel; stylus 2 times as long as scape, pedicel and postpedicel combined. Legs with dark brown to black and yellow colour pattern. Abdomen black, tergites and sternites mostly covered by grey microtrichia and by sparse, very short, setae; apical sternites with long, distinct, setae.

Type material (lost)

Holotype

SPAIN • Huelva, Cala; 22 Feb. 1915; C. Bolívar leg.

Paratypes

SPAIN • several specimens; Segovia, San Rafael; (spring) 1917; C. Bolívar leg.

Additional material (lost)

SPAIN • several specimens; Madrid, El Escorial; C. Bolívar leg. • Cuenca, Ciudad Encantada; J.G. Collado leg.

\section{Material examined}

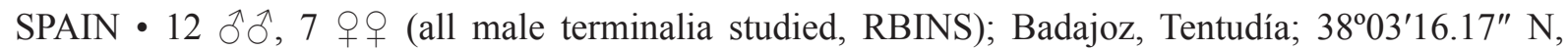
6020'14.7" W; 3 Apr. 2015; A.R. Gonçalves and R. Andrade leg. • 5 o $^{\lambda}, 5$ 우 ; same collection data as for preceding; ZFMK $\bullet 8 \widehat{\partial}, 13$ q $q$ (all male terminalia studied, RBINS); Segovia, El Espinar;

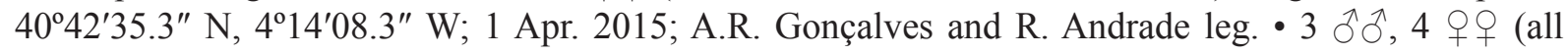


male terminalia studied, RBINS); Madrid, Montejo de la Sierra, Prádena del Rincón; 41 ${ }^{\circ} 03^{\prime} 03.6^{\prime \prime} \mathrm{N}$, $3^{\circ} 31^{\prime} 10.8^{\prime \prime}$ W; 23 Apr. 2017; A.R. Gonçalves and P. Álvarez leg. • 3 ổ $^{\lambda}$; Madrid, Montejo de la Sierra, Prádena del Rincón; 41 $02^{\prime} 40.8^{\prime \prime}$ N, 329'28.7" W; 23 Apr. 2017; A.R. Gonçalves and P. Álvarez leg. •

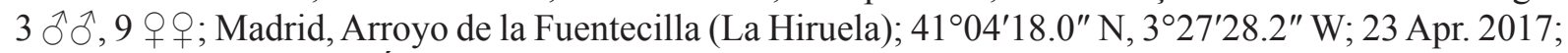

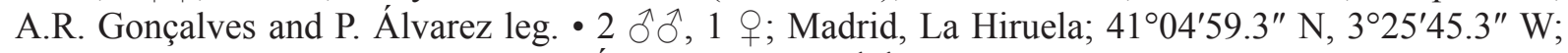

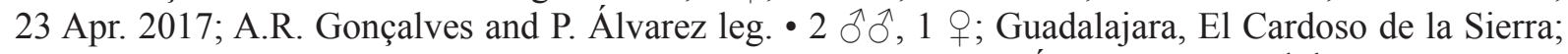

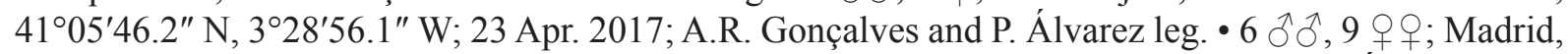
Pinilla de Buitrago; 4057'02.0" N, 343'11.6" W; 24 Apr. 2017; A.R. Gonçalves and P. Álvarez leg. •

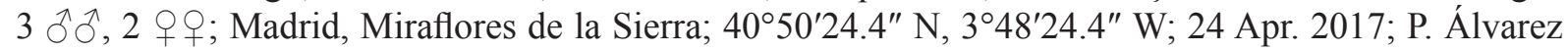

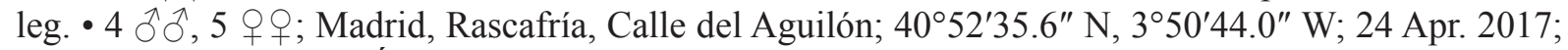

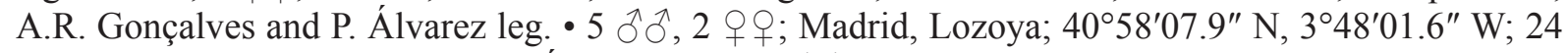
Apr. 2017; A.R. Gonçalves and P. Álvarez leg. 3 $\lesssim \widehat{\jmath}, 5$ 우; Madrid, Miraflores de la Sierra (Fuente

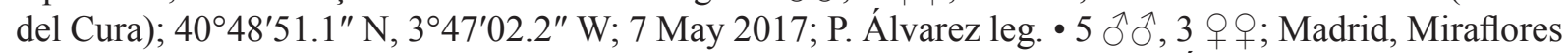
de la Sierra (Fuente del Cura); 4049'19.2" N, 347'21.5" W; 7 May 2017; P. Álvarez leg.

PORTUGAL • 1 ð, 2 우 (all male terminalia studied, RBINS); Porto de Mós, Arrimal; 39³1'54.6" N,

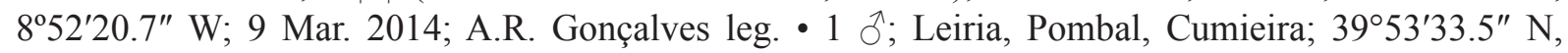
8³5'53.6" W; 18 Feb. 2017; S. Henriques leg.; NHMUK • 10 ô $^{\circ}, 12$ q $q$ (all male terminalia studied, RBINS); Porto de Mós, Arrimal; 39³1'54.6" N, 852'20.7" W; 11 Mar. 2017; A.R. Gonçalves and F.

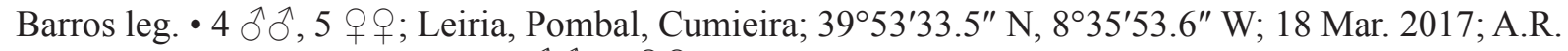

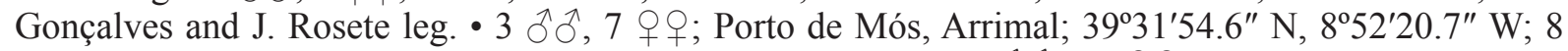

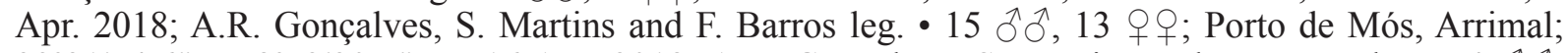

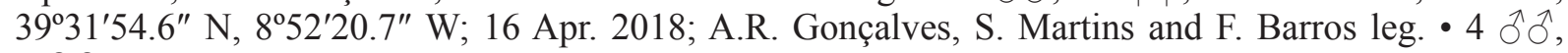
6 우 ; Porto de Mós; 39³1'56.53" N, 852'17.86" W; 16 Apr. 2018; A.R. Gonçalves, S. Martins and F. Barros leg. • 1 đ’; Porto de Mós; 39³3'52.41" N, 849'13.07" W; 16 Apr. 2018; A.R. Gonçalves,

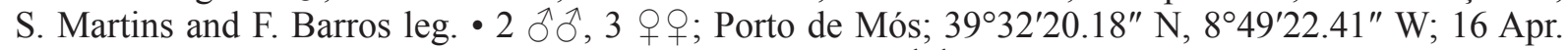

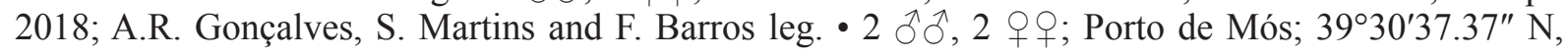

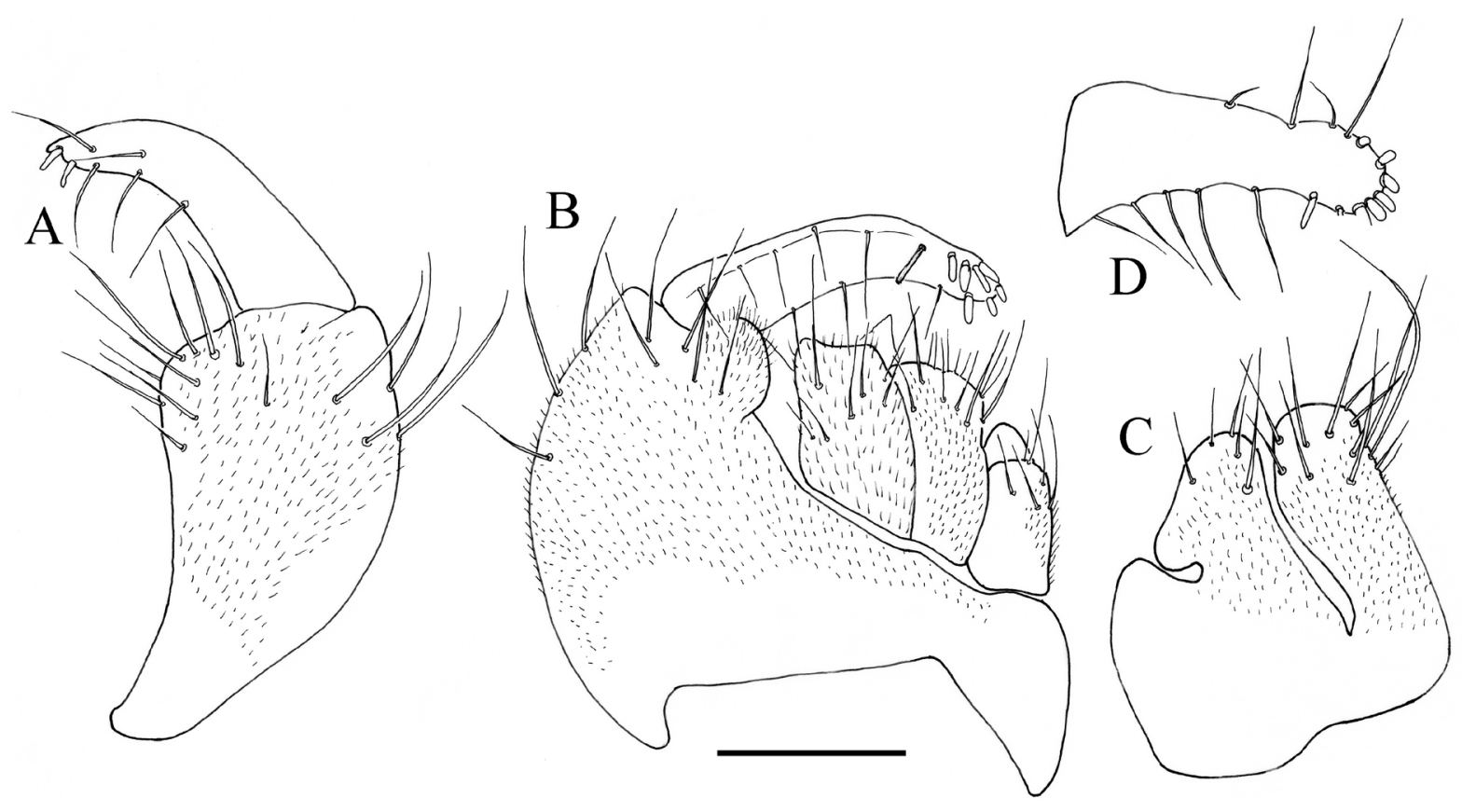

Fig. 6. Terminalia of Tachydromia iberica (Arias, 1919) from Spain, Madrid (RBINS). A. Right surstylus and right epandrial lamella. B. Epandrium with cerci. C. Left epandrial lamella and left surstylus. D. Right surstylus. Scale bar: $0.1 \mathrm{~mm}$. 
850'3.13" W; 16 Apr. 2018; A.R. Gonçalves, S. Martins and F. Barros leg. 1 Oे, 2 q + ; Porto de Mós; 39²6'16.57" N, 855'6.93" W; 16 Apr. 2018; A.R. Gonçalves, S. Martins and F. Barros leg.

\section{Redescription}

Similar to Tachydromia cantabrica sp. nov. except for the following:

\section{Male}

MEASUREMEnTs. Body length: 1.9-2.5 mm $(\mathrm{n}=5)$.

HeAD. Ocellar tubercle glabrous, shiny black. Lateroclinate ocellars ca $1 / 2$ smaller than length of postpedicel. Proclinate verticals ca $2 / 3$ shorter than length of postpedicel.

Antenna. Postpedicel 2 times as long as pedicel.

PALPUS. Less numerous setae present ventrally with a few distinct setae.

Thorax. Scutellum almost undistinguishable and postscutellum poorly developed. Postpronotal lobe with ca 8 setae laterally, ca 8 acrostichal setae, irregular biseriate, of equal length, and 6 similar other setae placed irregularly; notopleuron with 2 setae; 2 setae near mesothoracic spiracle; 2 long, incurvated prescutellar setae; scutellar setae absent.

WiNg. Absent.

LEGS. Dark brown to black with following yellow: trochanters, apical half of fore and mid femora, dorsal surface and basal $1 / 3$ of fore and mid tibiae, most of tarsomeres 1 and 2, except for black apical margin. Ciliation of hair-like setae absent from fore tibia. Spur absent.

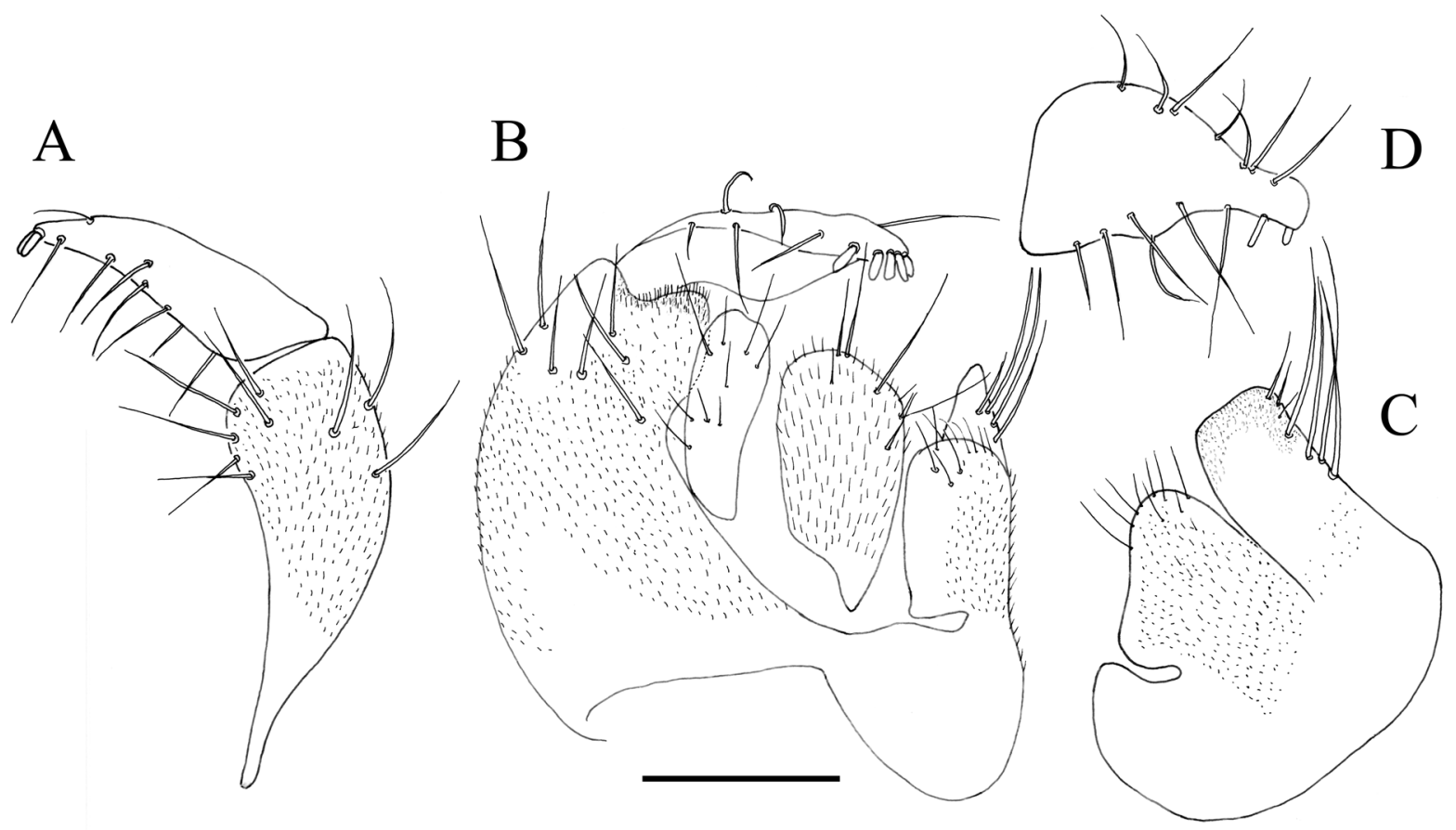

Fig. 7. Terminalia of Tachydromia iberica (Arias, 1919) from Spain, Segovia, El Espinar (Central System) (RBINS). A. Right surstylus and right epandrial lamella. B. Epandrium with cerci. C. Left epandrial lamella and left surstylus. D. Right surstylus. Scale bar: $0.1 \mathrm{~mm}$. 
АвDomen. Tergites and sternites with very short, sparse setae, except for apical sternites with longer, distinct setae.

Terminalia (Figs 6-8). Right surstylus long, mostly glabrous, except for stronger setae on dorsal and distal margins. Right epandrial lamella with long, irregularly placed setae on apical $1 / 3$. Cerci with long setae of unequal length mostly placed on apical $1 / 3$, Left epandrial lamella $1 / 3$ shorter than left cercus, deeply bilobed. Left surstylus almost twice as long as wide, $1 / 3$ shorter than cerci.

\section{Female}

Except for terminalia, no distinguishing features between sexes. Cerci pale brown with grey microtrichia and setae.

\section{Variability}

Main sources of variability are related to leg colouration, number of prescutellar setae and shape of right surstylus. In all populations, it is possible to find specimens with dark tarsi, instead of yellow. Regarding the right surstylus, in the southern population, this structure is usually long, narrowing distally (Fig. 6); in the Spanish central system, specimens usually have a very short, sub-triangular, right surstylus (Fig. 7); the Portuguese specimens, often have a very long and narrow surstylus (Fig. 8). However, it is possible to find variability concerning the shapes of right surstylus within the same population. Concerning the number of prescutellar setae, the usual number is 2 setae, but in all populations analysed it is possible to observe specimens with several prescutellar setae (ca 6).

\section{Distribution}

Spain and Portugal. It is known from the Serranía de Cuenca in eastern Iberia, Guadarrama mountains in the centre, in the foothills of the Sierra Morena mountains in the south, and in the Portuguese provinces of Beira Litoral and Estremadura in the west.

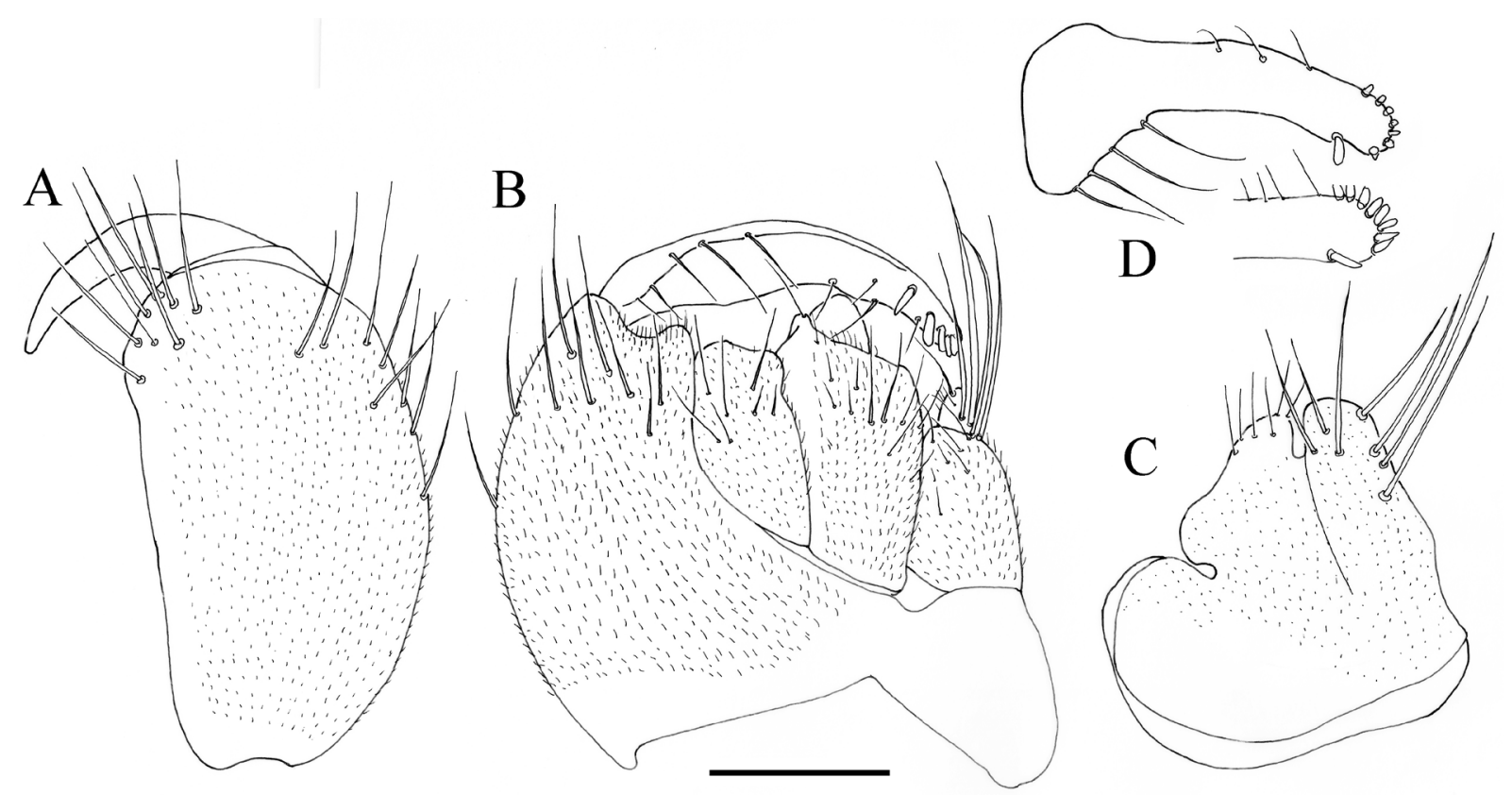

Fig. 8. Terminalia of Tachydromia iberica (Arias, 1919) from Portugal, Leiria, Porto de Mós (RBINS). A. Right surstylus and right epandrial lamella. B. Epandrium with cerci. C. Left epandrial lamella and left surstylus. D. Right surstylus. Scale bar: $0.1 \mathrm{~mm}$ 
Tachydromia lusitanica (Grootaert, Shamshev \& Andrade, 2009)

Figs 1, 9, 15A-B, 17A-B, 19A, 20E-F

Ariasella lusitanica Grootaert, Shamshev \& Andrade, 2009: 45.

Tachydromia lusitanica Shamshev \& Grootaert 2018: 425 (comb. nov.).

\section{Diagnosis}

Small $(2.25-2.40 \mathrm{~mm}(\mathrm{n}=3))$, slender, dark and hirsute species. Wing dimorphic: male stenopterous; bilobed distal apex, with very long digitation on distal margin (Fig. 20E). Stalk-like process dark brown on basal half, pale on distal half; lobed apex mostly black, digitation hyaline with black distal $1 / 3$ margin. Female micropterous, wing bilobate, squamiform, apical margin of each lobe bearing setae - the posterior lobe has 2 long setae and the anterior one 2 short setae (Fig. 20F). Wing veins not distinguishable in either sex. Occiput largely covered by grey microtrichia; 1 pair of long lateroclinate ocellars; 1 pair of proclinate verticals; palpi, proboscis and antennae black; postpedicel lanceolate, 2.5 times as long as pedicel; stylus 2 times as long as scape, pedicel and postpedicel combined. Thorax black with episternum densely covered with grey microtrichia, appearing sub-triangular in lateral view. Postpronotal lobe bearing 7 setae laterally, ca 9 acrostichal setae, irregular biseriate, of equal length; notopleuron with 1 strong, prominent seta plus 5 small setae; 2 strong prescutellar setae present laterally; scutellum with 2 similar setae medially. Legs mainly dark with pattern of yellow and brown to black; male fore tibia with dense ciliation of long hair-like setae; male mid with anteroventral apical spur produced into a barely noticeable apical elongation, about as long as diameter of tibia at apex (Fig. 19A); spur has several distinct setae and, on the distal half margin, 4 short, stout, curved, spinose setae. Abdomen black, tergites and sternites overall uniformly covered by grey microtrichia and long setae; apical sternites with longer setae. Terminalia (Fig. 9) subglobular, mostly covered with grey microtrichia, dark brown. Right surstylus produced into short projection, bearing long setae at the lateral margins and ca 11 denticles. Right cerci slightly longer than left, both enclosed in epandrial lamellae. Left epandrial lamella bilobed.

\section{Type material examined}

Holotype

PORTUGAL・ 1 ơ; Barcelos, Gilmonde; 4130'42.54" N, 8³8'57.33" W; 8 Mar. 2008; R. Andrade leg.; RBINS.

\section{Paratypes}

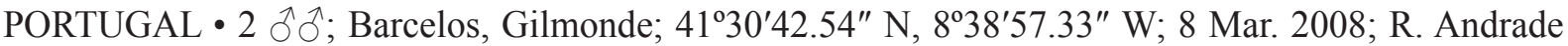

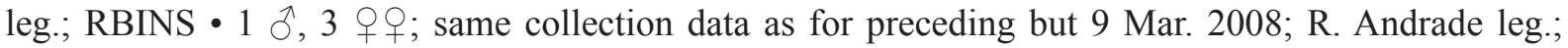
RBINS • 1 ; ; same collection data as for preceding but 17 Feb. 2009; R. Andrade leg.; RBINS • 1 $\delta$ same collection data as for preceding but 18 Feb. 2009; R. Andrade leg.; RBINS • $3 \hat{\jmath} \widehat{\jmath}, 3$ q 0 ; ; same collection data as for preceding but 23 Feb. 2009; R. Andrade leg.; RBINS.

\section{Additional material examined}

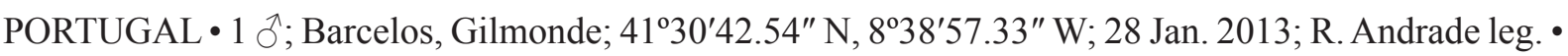

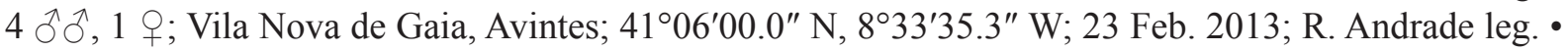

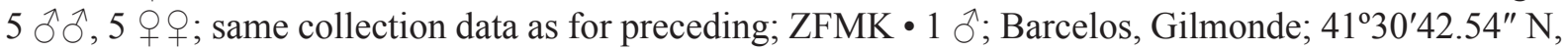
$8^{\circ} 38^{\prime} 57.33^{\prime \prime} \mathrm{W}$; 23 Feb. 2015; R. Andrade leg. 1 o'; same collection data as for preceding but 24 Feb.

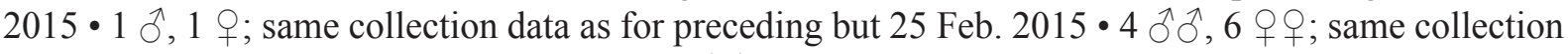
data as for preceding but $15 \mathrm{Apr}$. 2015・10 $\widehat{\jmath}, 8$ 우; same collection data as for preceding but 16

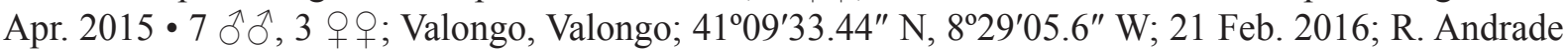

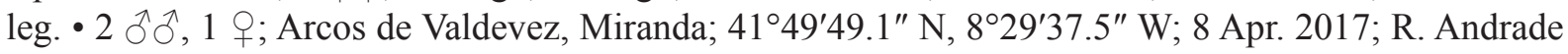

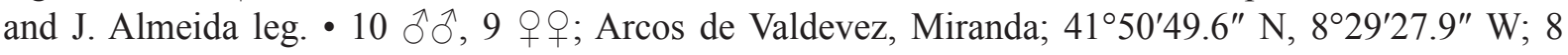




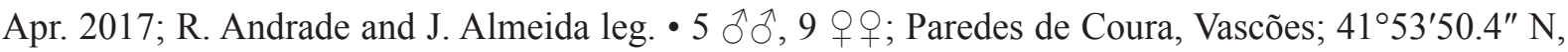

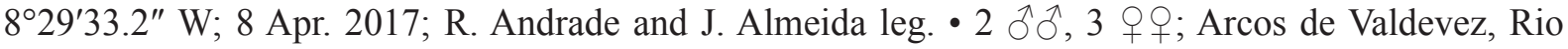
Frio; 41 ${ }^{\circ} 51^{\prime} 51.7^{\prime \prime}$ N, 830'21.4" W; 8 Apr. 2017; R. Andrade and J. Almeida leg. • 1 Oै, 3 q 우 Fafe,

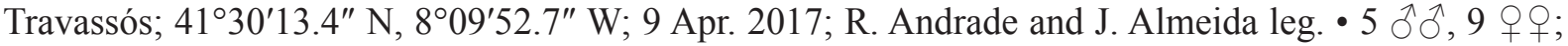

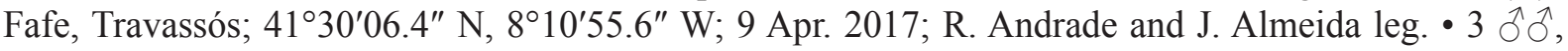

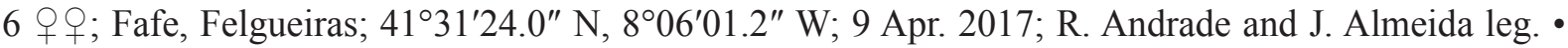

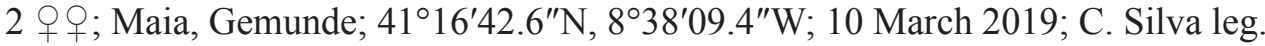

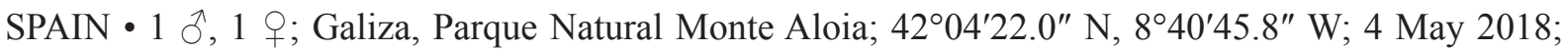

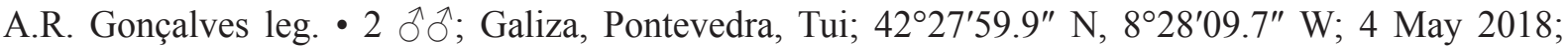

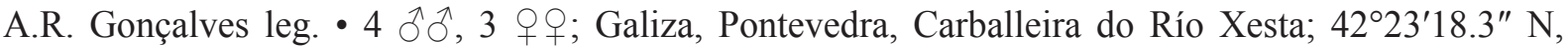
8²2'36.3" W; 4 May 2018; A.R. Gonçalves leg. • 1 §, 3 o $\circ$; Galiza, Pontevedra, Carballeira de San

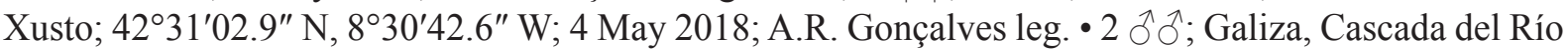

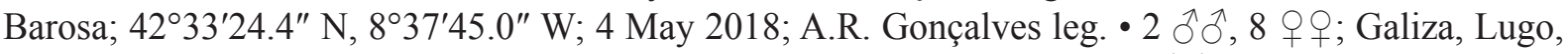

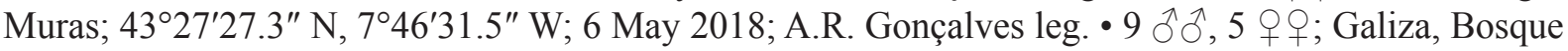

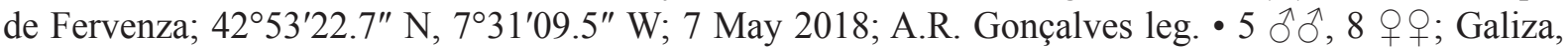

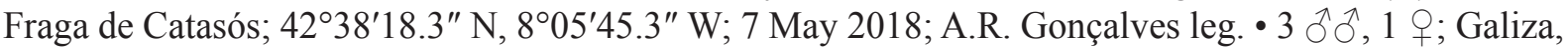
Ourense, Piñor; $42^{\circ} 31^{\prime} 17.3^{\prime \prime}$ N, $8^{\circ} 00^{\prime} 14.3^{\prime \prime}$ W; 7 May 2018; A.R. Gonçalves leg.

\section{Distribution}

Spain and Portugal. Restricted to the northwest of the Iberian Peninsula.

A

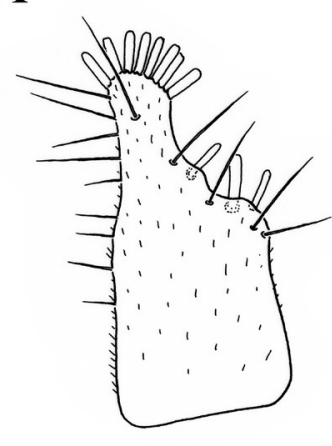

B

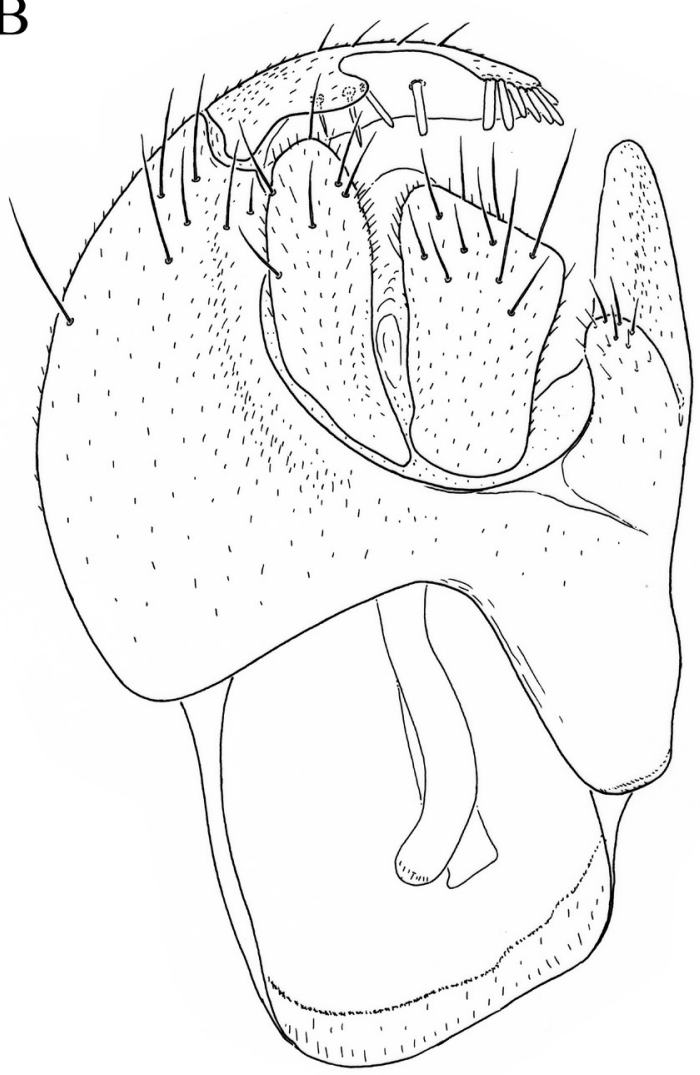

$\mathrm{C}$

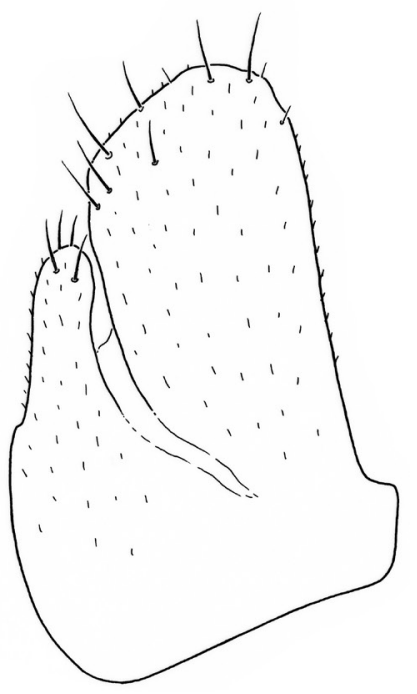

Fig. 9. Terminalia of the holotype of Tachydromia lusitanica (Grootaert, Shamshev \& Andrade, 2009) from Portugal, Braga, Gilmonde (RBINS). A. Right surstylus. B. Epandrium with cerci. C. Left epandrial lamella and left surstylus. Figure adapted from Grootaert et al. 2009. 
Tachydromia nigrohirta Gonçalves, Grootaert \& Andrade sp. nov. urn:lsid:zoobank.org:act:4DC85AF4-8CAA-429A-A6DF-1F071BD34857

Figs $1,10,15 \mathrm{C}-\mathrm{D}, 17 \mathrm{C}-\mathrm{D}, 19 \mathrm{I}, 20 \mathrm{G}-\mathrm{H}$

\section{Diagnosis}

Overall very dark and hirsute. Wing dimorphic: male stenopterous; lobed distal apex, suboval, with minute digitation on apical margin. Stalk-like process dark brown on basal half, pale on distal half; distal $2 / 3$ of lobe black, basal $1 / 3$ and digitation translucid; female micropterous, wing bilobate. Palpi, proboscis and antennae black. Postpedicel lanceolate, 2 times as long as pedicel; stylus 1.5 times as long as scape, pedicel and postpedicel combined. Legs mostly black except for yellowish to pale brown trochanters, knees and tarsomeres 1 and 2 . Abdomen black, tergites uniformly covered by grey microtrichia and long setae. It closely resembles $T$. lusitanica, from which it can mainly be distinguished by the noticeably darker leg colouration, male wing with only a minute digitation on apical margin, and male terminalia.

\section{Etymology}

Name composed of two Latin words: 'niger' (nigro) meaning 'black' and 'hìrtus' (hirta) meaning 'hairy'. The name combination indicates that this is a characteristically dark and hairy species.

\section{Type material examined}

\section{Holotype}

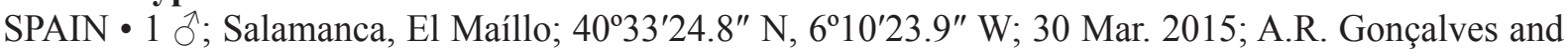
R. Andrade leg.; RBINS.

\section{Paratypes}

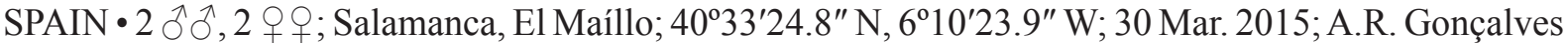

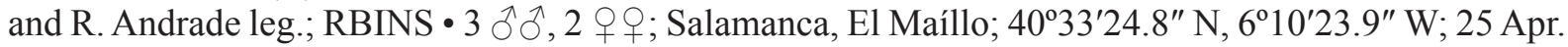
2017; A.R. Gonçalves leg.; RBINS.

\section{Additional material examined}

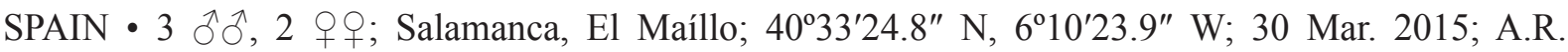

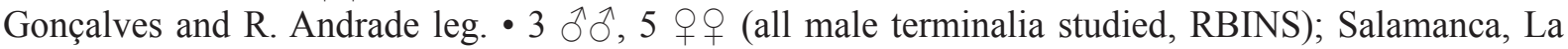

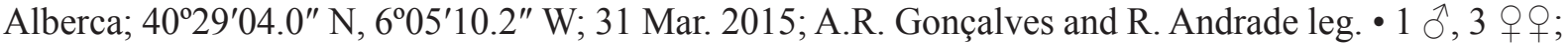

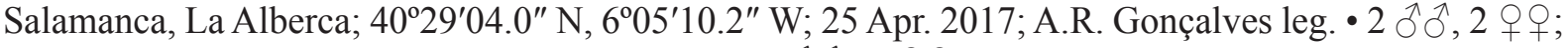

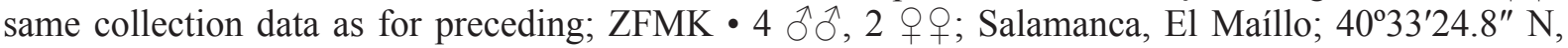

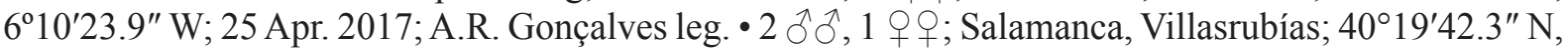
6³8'42.1" W; 25 Apr. 2017; A.R. Gonçalves leg.

\section{Description}

Similar to Tachydromia cantabrica sp. nov. except for the following:

\section{Male}

Measurements. Body length: 2.4-2.6 mm $(\mathrm{n}=5)$. Wing length: $0.7-0.8 \mathrm{~mm}(\mathrm{n}=5)$.

HEAD. Ocellar tubercle glabrous, shiny black. Lateroclinate ocellars ca $1 / 3$ smaller than length of postpedicel. Proclinate verticals ca $1 / 2$ as long as postpedicel.

AnTEnNA. Postpedicel lanceolate, 2 times as long as pedicel. Stylus 1.5 times as long as scape, pedicel and postpedicel combined.

THORAX. Postpronotal lobe with ca 7 setae laterally.

WING. Stalk-like portion dark brown on basal half, pale on distal half (Fig. 20G). 
LEGS. Black, except for yellowish to brown trochanters, knees and tarsomeres 1 and 2. Fore tibia with dense ciliation of long hair-like setae (distinctively larger than maximum diameter of tibia) with curved tips. Mid tibia anteroventral apical spur with distinct apical elongation (Fig. 19I), on basal half margin with 4 short, stout, curved spinose setae.

Terminalia (Fig. 10). Left epandrial lamella $1 \frac{1}{3}$ shorter than left cercus, deeply bilobed. Left surstylus 2 times as long as wide.

\section{Female}

Similar to male, except for following features: micropterous, wing round, brownish, bilobate, apical margin of each lobe bearing setae, posterior lobe with 1 long seta and the anterior with 3 short setae, both covered with grey microtrichia (Fig. 20H); legs covered with regular rows of setae; spur on mid tibia absent; cercus pale brown with grey microtrichia and setae; no longer setae on apical sternites.

\section{Distribution}

Spain. Only known from a few localities in the western part of the Iberian Central System.

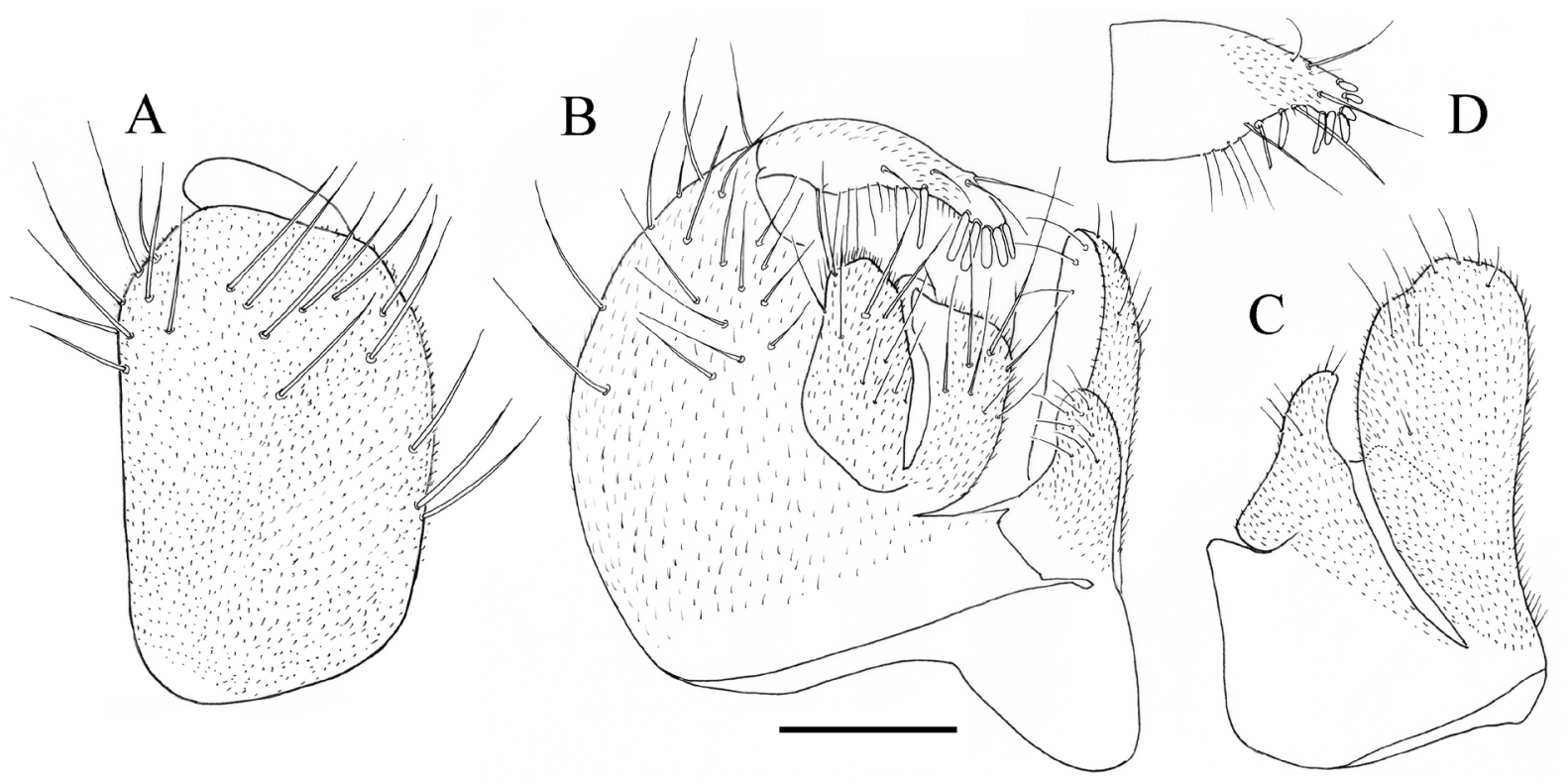

Fig. 10. Terminalia of Tachydromia nigrohirta Gonçalves, Grootaert \& Andrade sp. nov., holotype (RBINS). A. Right surstylus and right epandrial lamella. B. Epandrium with cerci. C. Left epandrial lamella and left surstylus. D. Right surstylus. Scale bar: $0.1 \mathrm{~mm}$.

Tachydromia pandellei (Séguy, 1941)

Figs 1, 11, 16G-H, 18I-J, 19B, 21A, C

Ariasella pandellei Séguy, 1941: 4.

Tachydromia pandellei Shamshev \& Grootaert 2018: 425 (comb. nov.).

\section{Diagnosis}

Overall shiny black with distinct yellow parts. Wing dimorphic: male stenopterous; wing with cordiform (French populations) or lobed apex (Spanish populations); stalk-like portion yellow to light brown; lobed 
apex with basal half hyaline, distal half black; female stenopterous, stalk-like portion yellowish with minute lobed apex pale brown. Antennae yellow with brownish postpedicel; palpi yellow; proboscis black; postpedicel roundish, approximately as long as pedicel. Legs overall yellow with brownish hind femora and tibiae, tarsomeres yellow and black. Abdomen black, tergites and sternites overall covered with grey microtrichia and setae.

\section{Type material examined}

Lectotype (here designated in order to fix the identity of the species)

FRANCE • 1 §̊; Hautes-Pyrénées, Arrens-Marsous; 28 Jun. 1879; L. Pandellé leg.; MHNP-1256.

\section{Paralectotypes}

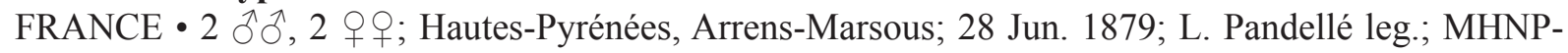
1256.

\section{Additional material examined}

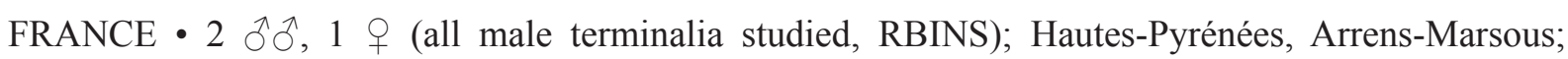

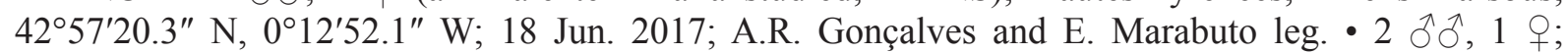
Hautes-Pyrénées, Arrens-Marsous, Arrens, Route d'Aste; 4256'14.9" N, 0¹3'45.9" W; 18 Jun. 2017; A.R. Gonçalves and E. Marabuto leg. -3 đô, 6 우; Hautes-Pyrénées, Barèges, Touët et Labach; 42 ${ }^{\circ} 4^{\prime} 08.1^{\prime \prime} \mathrm{N}, 0^{\circ} 06^{\prime} 04.0^{\prime \prime}$ E; 19 Jun. 2017; A.R. Gonçalves and E. Marabuto leg. • 1 +; Hautes-Pyrénées, Campan; 42 $55^{\prime} 31^{\prime \prime}$ N, 0¹1'49" E; 20 Jun. 2017; E. Marabuto leg.

SPAIN • 5 우; Burgos, Villasur de Herreros; 42 ${ }^{\circ} 18^{\prime} 26.4^{\prime \prime}$ N, 319'59.1" W; 15 May 2014; A.R.

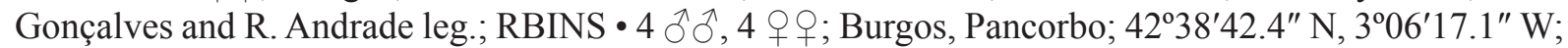
11 May 2015; A.R. Gonçalves and R. Andrade leg. 1 1 , 5 우; same collection data as for preceding;

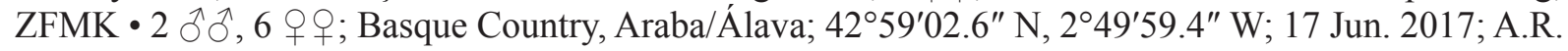
Gonçalves leg.

\section{Redescription}

Similar to Tachydromia cantabrica sp. nov. except for the following:

\section{Male}

Measurements. Body length: 2.4-2.8 mm $(\mathrm{n}=5)$. Wing length: $0.9-1.1 \mathrm{~mm}(\mathrm{n}=5)$.

HEAD. Ocellar tubercle glabrous. Lateroclinate ocellars 2 times as long as postpedicel. Proclinate verticals 1.5 times as long as postpedicel, numerous very long setae on occiput.

AnTENNA. Scape and pedicel yellow, postpedicel brown. Postpedicel oval, 2 times as long as wide and slightly longer than pedicel; stylus slightly more than 3 times as long as scape, pedicel and postpedicel combined.

PALPuS. Brown in ground colour.

Thorax. Poorly differentiated sclerites, with slightly distinguishable postpronotal lobe, notopleuron, episternum, mesopleuron, pteropleuron, sternopleuron and hypopleuron. Postpronotal lobe very small, mesonotum somewhat humped, scutellum well defined but very short, postscutellum longer and metanotum well developed. Prosternum and episternum densely covered by grey microtrichia. Postpronotal lobe bearing 12 setae laterally, notopleuron with 1 strong, prominent, very long seta, plus 3 smaller ones; 3 setae near base of wing, prescutellum bearing 4 setae, inner setae longer.

WING. Lobed apex cordiform. Stalk-like portion rigid, yellow except for brown basal portion; lobed apex with basal half hyaline (appearing silver under certain light conditions), distal half black (Fig. 21A). 
LEGS. Overall yellow, except for following brown to black portions: posterodorsal surface of coxae, apical $1 / 4$ dorsal surface, posterior and anterior surfaces of hind femur, most of hind tibia, tarsomere 5 of fore and mid-legs, distal apex of tarsomeres 1 and 2, distal $1 / 3$ of tarsomere 3, distal $3 / 4$ of tarsomeres 4 and 5. Mid tibia anteroventral apical spur produced into distinct and long apical elongation (Fig. 19B), longer than diameter of tibia at apex; mostly glabrous ventrally but dorsally covered by microtrichia, with a few distinct setae and, on basal half margin, 3 short, stout, curved setae. Elongation mostly glabrous, with a few setae arising marginally and apically.

Terminalia (Fig. 11). Right epandrial lamella with long, erect setae mostly on apical half. Right surstylus bifurcated into short projection and very long and slender projection; mostly glabrous but with long, curved lateral setae and 2 denticle-like setae at distal margin of longer projection; short projection with similar setae at distal margin. Right cercus slightly longer than left, both enclosed in epandrial lamellae. Left epandrial lamella as long as left cercus. Left surstylus subcylindrical, narrowing proximately, 4 times as long as wide, as long as right cercus, with setae on lateral margins and apical 1/3.

\section{Female}

Similar to male, except for following features: stenopterous (length of wing $(\mathrm{n}=2)$ : $0.7-0.8 \mathrm{~mm}$ ), with very minute lobed apex, stalk-like portion yellowish with lobe light brown, covered by grey microtrichia (Fig. 21C); legs covered with regular rows of setae, with distinct circle of setae on fore femur and anteroapical setae on coxae, but no other distinctive hairs or setae; spur on mid tibia absent; cercus pale brown with grey microtrichia and setae.

\section{Variability}

There is a variability in the shape of the wing lobe in males between the populations sampled in the French Pyrenees compared with those from Spain. In the former, the lobed apex is distinctively large and cordiform, while in the latter the lobed apex is comparatively smaller and oval.

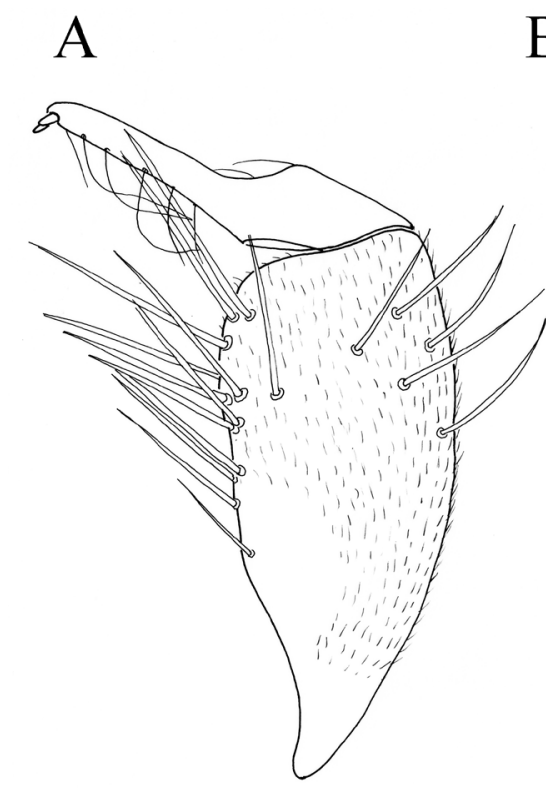

B

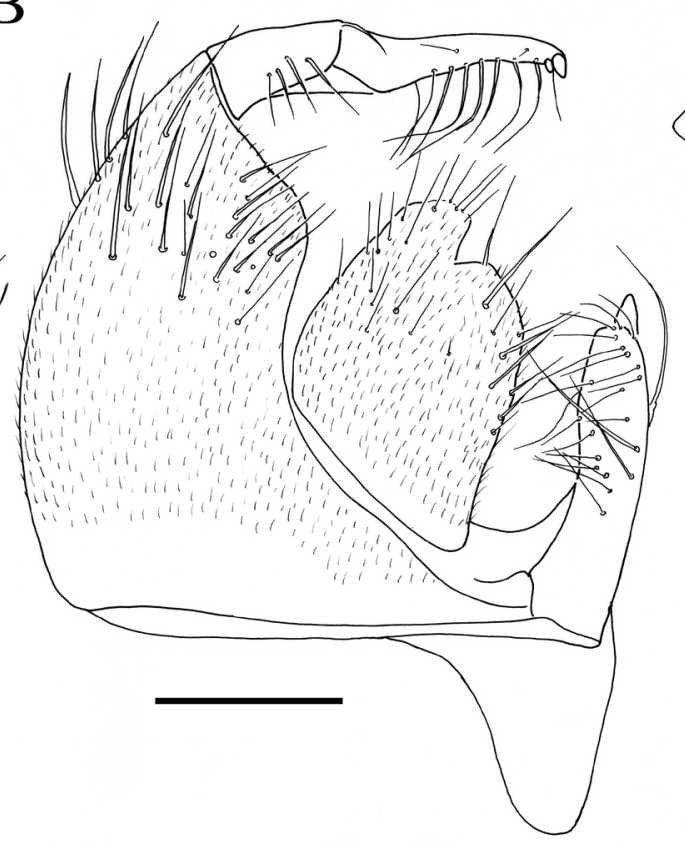

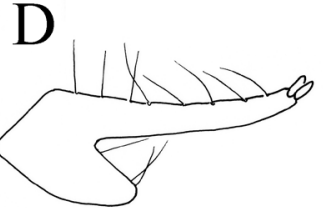

$\mathrm{C}$

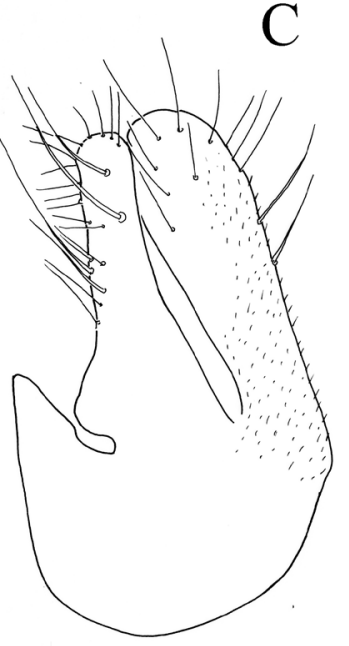

Fig. 11. Terminalia of the topotype of Tachydromia pandellei (Séguy, 1941) from France, Hautes-Pyrénées, Arrens-Marsous, lectotype (RBINS). A. Right surstylus and right epandrial lamella. B. Epandrium with cerci. C. Left epandrial lamella and left surstylus. D. Right surstylus. Scale bar: $0.1 \mathrm{~mm}$. 


\section{Distribution}

Spain and France. It is known from the French Pyrenees and a few localities in the northern Spanish province of Burgos and the Basque Country.

Tachydromia pieltaini (Gil Collado, 1936)

Figs 1, 12, 16E-F, 18G-H, 19C, 21B-C

Ariasella pieltaini Gil Collado, 1936: 191.

Tachydromia pieltaini - Shamshev \& Grootaert 2018: 425 (comb. nov.).

\section{Diagnosis}

Shiny black with distinct yellow parts. Wing dimorphic: male stenopterous; wing with oval apex; stalklike process yellow to light brown; lobed apex with hyaline cells, veins and distal margin black; female stenopterous, stalk-like portion yellowish with minute lobed apex pale brown. Proboscis and antennae black; palpi yellow; postpedicel roundish, approximately as long as pedicel. Legs overall yellow only with the distal tarsomeres black. Abdomen black, tergites and sternites overall covered with setae; grey microtrichia present at last apical tergite and most sternites, resulting in shiny appearance of dorsal surface.

Type material (not examined, lost)

SPAIN • 1 क; Asturias, Porra de Enol; C. Bolívar leg.

\section{Additional material examined}

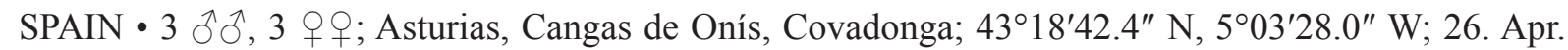

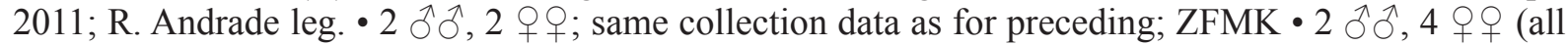
male terminalia studied, RBINS); Asturias, Cangas de Onís; 4321'14.6" N, 507'25.9" W; 9 Apr. 2016; A.R. Gonçalves leg.

\section{Redescription}

Similar to Tachydromia cantabrica sp. nov. except for the following:

Male (previously undescribed)

MEASUREMENTS. Body length: 2.6-2.9 mm $(\mathrm{n}=5)$. Wing length: 0.9-1.1 mm $(\mathrm{n}=5)$.

HEAD. Ocellar tubercle glabrous. Lateroclinate ocellars 2 times as long as postpedicel. Proclinate verticals 1.8 times as long as postpedicel.

AnTEnNa. Yellow. Postpedicel roundish, as long as wide and, approximately as long as pedicel; stylus almost 4 times as long as scape, pedicel and postpedicel combined.

PaLPus. About 4 times as long as wide. Yellow in ground colour.

Thorax. Postpronotal lobe, notopleuron, episternum, anepisternum, sternopleuron, katepimeron and meron weakly differentiated. Scutellum short, postscutellum longer and metanotum well developed. Prosternum and basal half of episternum densely covered by grey microtrichia. Postpronotal lobe bearing 7 setae laterally, 5 acrostichal setae, irregularly placed; notopleuron with 1 strong, prominent, very long seta, plus 3 smaller ones

WING (Fig. 21B). Lobed apex oval. Stalk-like portion rigid, yellow to light brown; lobed apex with hyaline cells, veins and distal margin black. Venation very reduced (costal, longitudinal and cross veins distinguishable), forming 4 cells. 
LEGs. Overall yellow, with the following brown to black: dorsal strip on fore and mid femora, posterior coxae, tarsomere 5 of fore and mid-legs, apical portions of tarsomeres 2 and 3, tarsomeres 4 and 5 of hind leg. Mid trochanter with several black anteroventral marginal setae. Mid femur with small roundish posteroventral projection on basal surface with several black denticle-like setae and ca 3 black setae. Mid tibia anteroventral apical spur produced into distinct, long elongation (Fig. 19C); slightly longer than diameter of tibia at apex. Spur covered with microtrichia and $>10$ short, blunt denticle-like setae; additionally, with 6 longer, stout, curved setae along lateral margin. Elongation mostly glabrous with a few setae arising marginally and apically.

АвDOMEN. Shiny black, with grey microtrichia covering only last tergite and almost all sternites, except for sternites 1 and 2. Tergites and sternites overall covered with setae, except for dorsal surface of all tergites and most of sternite 1 (distal margin with a few setae); apical sternite and tergite with longer setae.

Terminalia (Fig. 12). Right surstylus short with irregular margins, narrowing distally, bearing long setae, with several (ca 8) distinct denticle-like setae aggregated on distal margin. Right cercus longer than left. Right cercus with setae on apical $1 / 3$; left cercus with setae of unequal lengths on apical half and 2 long apical setae. Left epandrial lamella $1 / 3$ shorter than left cercus, with setae of similar length on apical half of ventral surface and on apex of dorsal margin. Left surstylus longer than right cercus, with very long setae on lateral and apical margins.

\section{Female}

Similar to male, except for following features: stenopterous (length of wing $(\mathrm{n}=2)$ : $0.7-0.8 \mathrm{~mm}$ ), with very minute lobed apex, stalk-like portion yellowish with lobe light brown, covered by grey microtrichia (Fig. 21C); legs covered with regular rows of setae, with distinct circle of setae on fore femur and anteroapical setae on coxae; without other distinctive hairs or setae; spurs on mid tibia absent; cercus pale brown with grey microtrichia and setae.

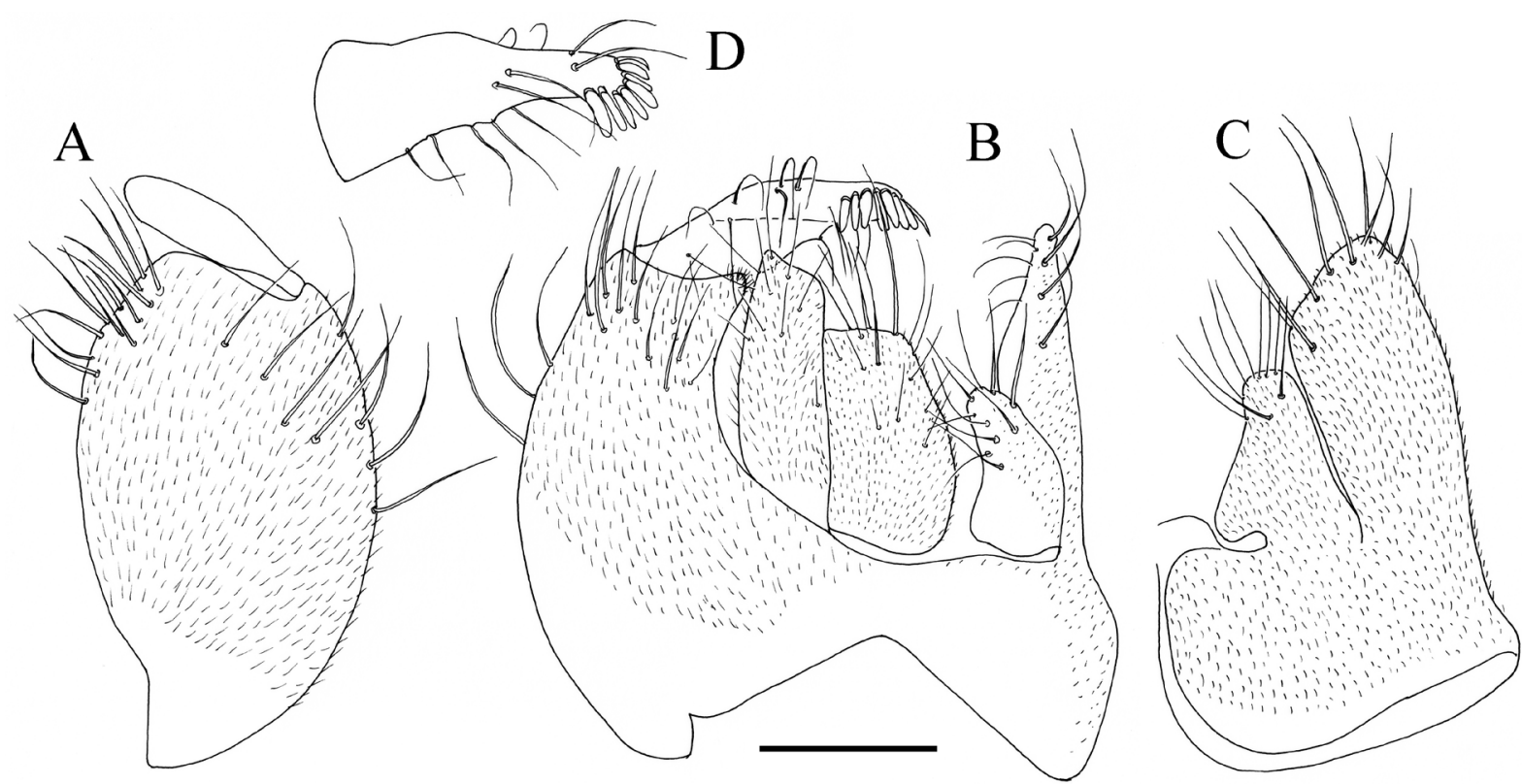

Fig. 12. Terminalia of Tachydromia pieltaini (Gil Collado, 1936) from Spain, Asturias, Covadonga (RBINS). A. Right surstylus and right epandrial lamella. B. Epandrium with cerci. C. Left epandrial lamella and left surstylus. D. Right surstylus. Scale bar: $0.1 \mathrm{~mm}$. 


\section{Distribution}

Spain. Only known from the Picos de Europa mountain range.

Tachydromia semiaptera (Gil Collado, 1923)

Figs 1, 13, 16C-D, 18E-F, 19E-F, 21D-E

Ariasella semiaptera Gil Collado, 1923: 150 (male and female).

Tachydromia semiaptera - Shamshev \& Grootaert 2018: 425 (comb. nov.).

\section{Diagnosis}

Overall dark species with distinct yellow parts. Wing dimorphic: male stenopterous; oblong apex; stalklike portion light brown with distinct black spot on lobed apex; female micropterous, with wing round, brownish. Palpi, proboscis and antennae black; postpedicel roundish, approximately as long as pedicel. Legs with colour pattern of yellowish and dark brown to black. Male legs with following features: fore tibia black, stout and inflated; mid tibia bearing two projections and row of five spinose setae on posteroventral basal surface. Abdomen black, overall covered with microtrichia and sparse setae; two apical sternites with long setae.

Type material (not examined, lost)

SPAIN • ca 20 specimens; Ávila, Valle de Iruelas; May 1919; C. Bolívar leg.

Additional material (not examined, lost)

SPAIN • Ciudad Real, Navas de Estena; C. Bolívar leg. • Madrid, El Escorial; C. Bolívar leg.

\section{Material examined}

Topotype

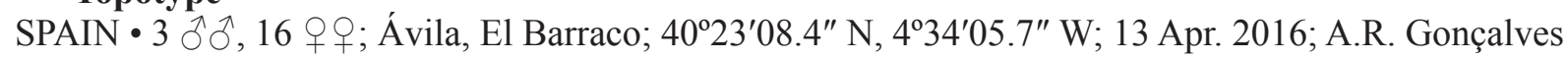
and R. Andrade leg.; RBINS.

\section{Additional material}

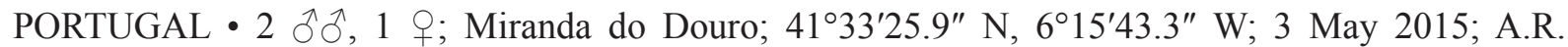

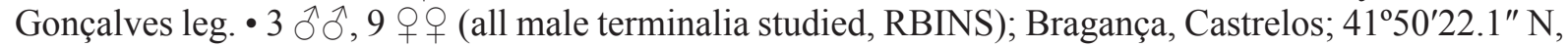

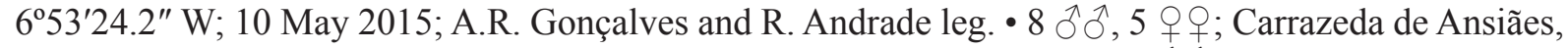

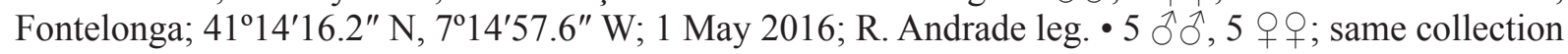
data as for preceding; ZFMK.

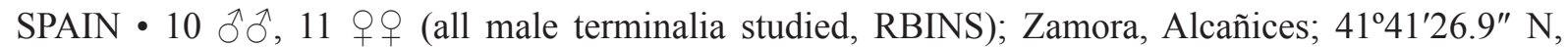

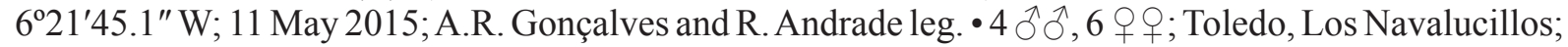

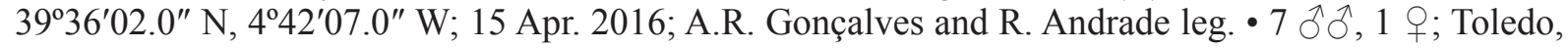
Los Navalucillos; 39³4'25.0" N, 444'57.0" W; 15 Apr. 2016; A.R. Gonçalves and R. Andrade leg. •

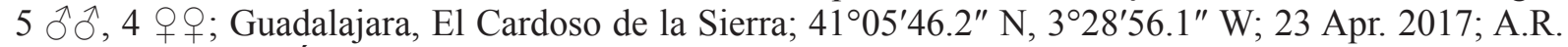
Gonçalves and P. Álvarez leg. • 4 $\widehat{\partial}, 3$, + ; Guadalajara, El Cardoso de la Sierra (Río Berbellido);

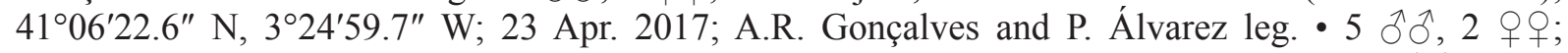

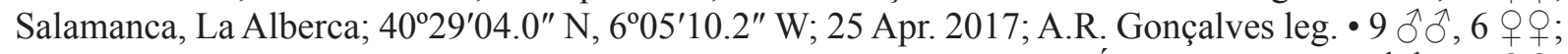

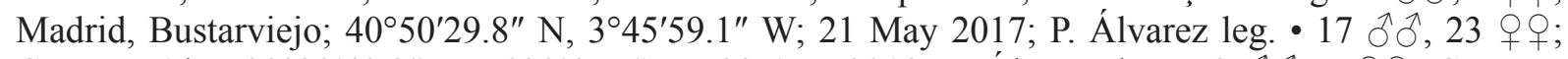
Cáceres, Alía; 39³0'40.3" N, 5²0'47.7" W; 23 Apr. 2018; P. Álvarez leg. • 3 ồ ô, 5 우 of Cáceres, Berzocana; 39²4'55.6" N, 5²5'10.3" W; 23 Apr. 2018; A.R. Gonçalves and P. Álvarez leg.

\section{Redescription}

Similar to Tachydromia cantabrica sp. nov. except for the following: 


\section{Male}

Measurements. Body length: $2.4-2.8 \mathrm{~mm}(\mathrm{n}=5)$. Wing length: $1.2-1.3 \mathrm{~mm}(\mathrm{n}=5)$.

HEAD. Lateroclinate ocellars 2.5 times as long as postpedicel. Proclinate verticals 2 times as long as postpedicel.

Antenna. Light brown. Postpedicel roundish, as long as wide; stylus more than 4 times as long as scape, pedicel and postpedicel combined.

THorax. With very long black setae. Well-distinguished sclerites, with clear separation between anepisternum and anepimeron; postpronotal lobe very large; scutellum and metanotum well developed, postscutellum poorly developed. Prosternum and episternum densely covered by grey microtrichia. Postpronotal lobe with 5 setae laterally, mesonotum with 6 scattered setae of equal length; 5 setae near alar region; notopleuron with 1 strong, prominent, very long seta; 2 setae near posterior margin of postpronotal lobe; scutellum with 2 strong, long setae medially.

WING (Fig. 21D). Lobed apex oblong, without digitation. Stalk-like process very flexible, light brown with distinct black spot on lobed apex. Venation very reduced (costal, longitudinal and cross veins distinguishable), forming 4 cells.

LEGS. Fore tibia stout and inflated distally. Overall dark brown to black, following portions yellow: trochanters, anterior apical half and apex of fore and mid tibiae, dorsal strip and apical half of fore and mid tibiae, fore and mid tarsomeres $1,2,3$, basal $2 / 34$, hind tarsomeres 1 and 2 . Fore tibia with rows of long, erect setae; mid tibia bearing row of 5 strong, spine-like posteroventral basal setae. Mid tibia with 2 anteroventral apical projections (Fig. 19E-F): 1 slightly shorter than diameter of tibia at apex; clothed in microtrichia, several distinct setae and 2 short, stout, curved spinose setae on margin of distal half; second projection as long as diameter of tibia at apex with a few long setae.

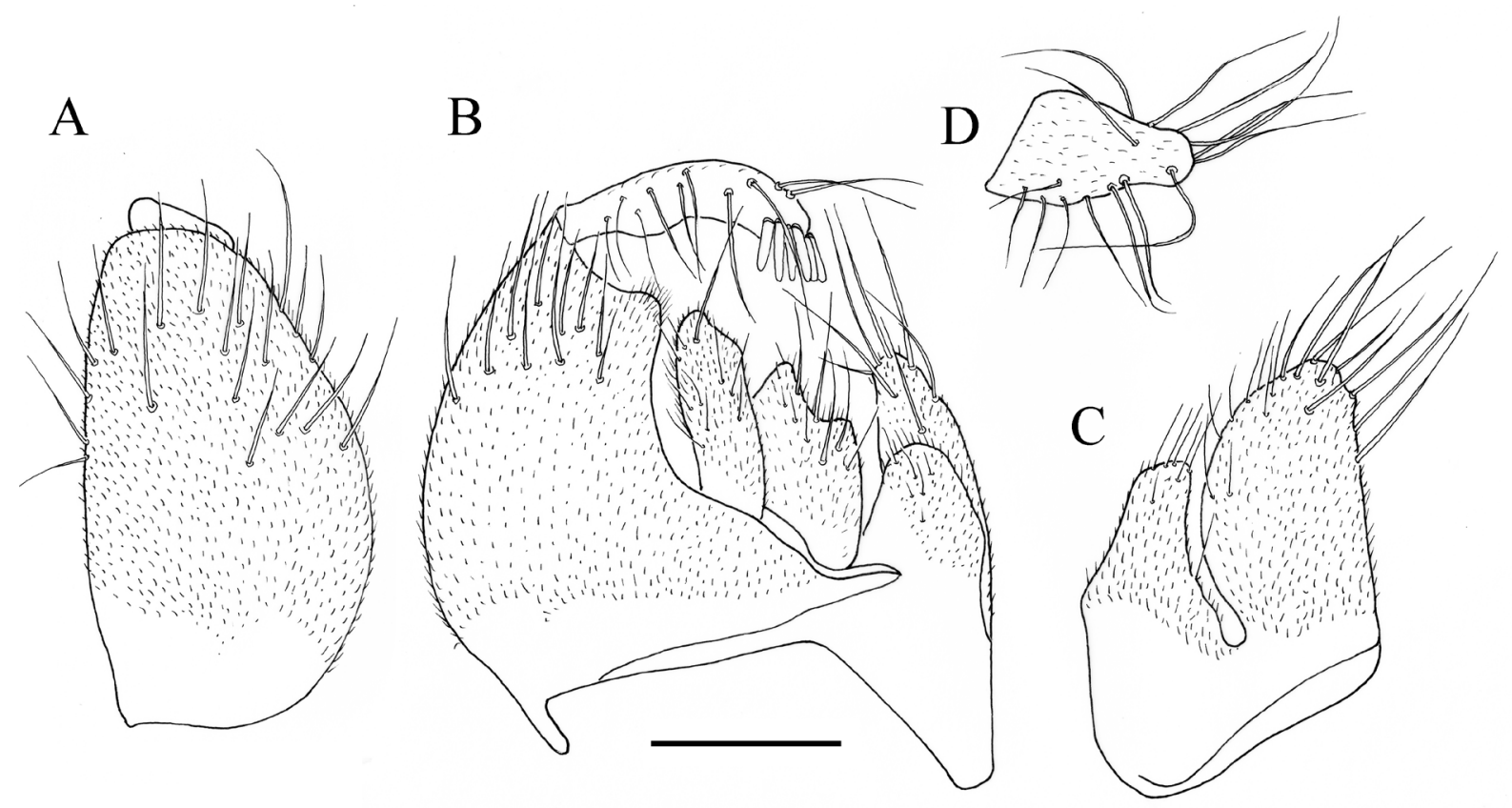

Fig. 13. Terminalia of Tachydromia semiaptera (Gil Collado, 1923) (RBINS). A. Right surstylus and right epandrial lamella. B. Epandrium with cerci. C. Left epandrial lamella and left surstylus. D. Right surstylus. Scale bar: $0.1 \mathrm{~mm}$. 
Terminalia (Fig. 13). Right epandrial lamella with long, erect setae on apical half. Right surstylus short, narrowing distally, with sparse microtrichia, bearing long, irregularly curved setae, with several (ca 6) distinct denticle-like setae, aggregated on distal margin. Right cercus with setae on apical half and distinct apical seta; left cercus with apical setae of unequal lengths. Right cercus longer than left, both enclosed in epandrial lamellae. Left epandrial lamella shorter than left cercus, deeply bilobed. Left surstylus 1.5 times as long as wide, approximately as long as right cercus, with very long setae, lateroclinate, facing inwards.

\section{Female}

Similar to male, except for following features: micropterous, with wing round, brownish, bearing 1 long seta and 1 short seta on apical margin, covered by grey microtrichia (Fig. 21E); legs covered with regular rows of setae, with distinct apical setae on fore femur and anteroapical setae on coxae; without other distinctive setae; spurs on mid tibia absent; cercus pale brown with grey microtrichia and setae.

\section{Distribution}

Spain and Portugal. It is known from several localities along the Iberian Central System, and from the Montes de Toledo mountain range, the northeast of Portugal and from one locality in the Spanish province of Zamora near the border with Portugal.

Tachydromia stenoptera Gonçalves, Grootaert \& Andrade sp. nov. urn:1sid:zoobank.org:act:AB1CBE5D-22D9-4153-9EE5-FA711157B977

Figs 1, 14, 15G-H, 17G-H, 19G, 21F-G

\section{Diagnosis}

Overall very dark. Wing dimorphic: male stenopterous; wing with slightly lobed distal apex, dark for most part and lobe black and white; female micropterous, wing bilobate. Palpi, proboscis and antennae black; postpedicel lanceolate, ca 1.5 times as long as pedicel. Legs almost completely black. Abdomen black, tergites mostly glabrous and without grey microtrichia.

\section{Etymology}

The name of this species means 'narrow wing' and derives from the combination of two Greek words: the prefix steno- (stenos), meaning 'narrow', with the suffix -ptera (pterá), meaning 'wing'. Hence, the name reflects the very narrow lobed distal apex of the male wing.

\section{Type material examined}

\section{Holotype}

PORTUGAL • 1 đ̊; Gouveia, São Pedro; 40²9'10.9" N, 7³4'38.5" W; 25 Apr. 2013; A.R. Gonçalves and R. Andrade leg.; RBINS.

\section{Paratypes}

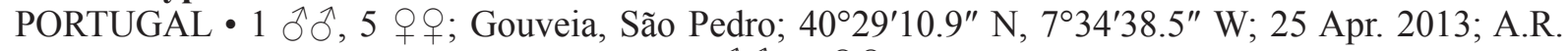
Gonçalves and R. Andrade leg.; RBINS • 5 ภำ, 5 우; Guarda, Panóias de Cima; 40²9'10.2" N, 7¹3'18.4" W; 1 Apr. 2017; A.R. Gonçalves and R. Andrade leg.; RBINS.

\section{Additional examined material}

PORTUGAL • 1 क; Manteigas, São Pedro; 40¹9'07.0" N, 7³4'37.4" W; 25 Apr. 2013; A.R. Gonçalves

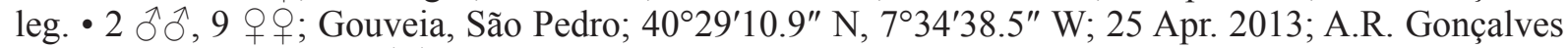

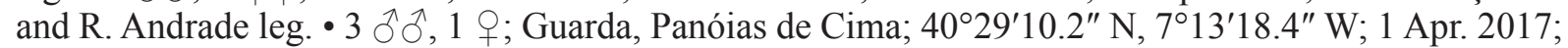
A.R. Gonçalves and R. Andrade leg. $-5 \hat{\delta^{\lambda}}, 5$ 우 ; same collection data as for preceding; ZFMK •

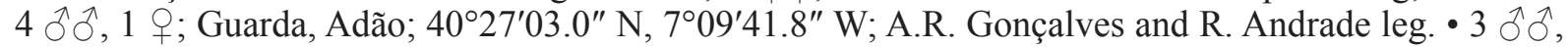
4 웅 S Sabugal, Quadrazais; $40^{\circ} 18^{\prime} 30.6^{\prime \prime}$ N, 6 6 59'08.7" W; 1 Apr. 2017; A.R. Gonçalves and R. Andrade leg. • 1 ô, 1 o; Sabugal, Seixo do Côa; 40²4'48.0" N, 701'07.6" W; 1 Apr. 2017; A.R. Gonçalves 


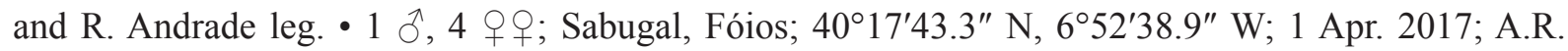
Gonçalves and R. Andrade leg.

\section{Description}

Similar to Tachydromia cantabrica sp. nov. except for the following:

\section{Male}

Measurements. Body length: 2.1-2.8 mm ( $\mathrm{n}=5)$. Wing length: $0.8 \mathrm{~mm}-0.9 \mathrm{~mm}(\mathrm{n}=5)$.

HEAD. Lateroclinate ocellars same length as postpedicel. Proclinate verticals ca $3 / 4$ as long as postpedicel.

Antenna. Postpedicel lanceolate, ca 2 times as long as pedicel.

THORAX. Postpronotal lobe bearing ca 7 setae laterally, ca 6 acrostichal setae, scattered; notopleuron with 1 strong, prominent seta; 6 small setae near mesothoracic spiracle.

WING. Slightly lobed distal apex, without digitation (Fig. 21F).

LEGS. Overall black; ventral and dorsal posterior surface of coxae, trochanter, basal 0.1 ventral surface of femora and knees, paler. Fore tibia bearing sparse ciliation of hair-like setae slightly longer than maximum diameter of tibia. Mid tibia anteroventral apical spur with 4 short, stout, curved spinose setae on distal half margin.

ABDomen. Tergites with grey microtrichia only on anterior margin of tergite 1 and near spiracles; sternites overall covered by grey microtrichia. Tergites with few and scattered setae, mostly present on posteromarginal surface and near spiracles; sternites with evenly distributed setae; apical sternites with long, distinct setae.

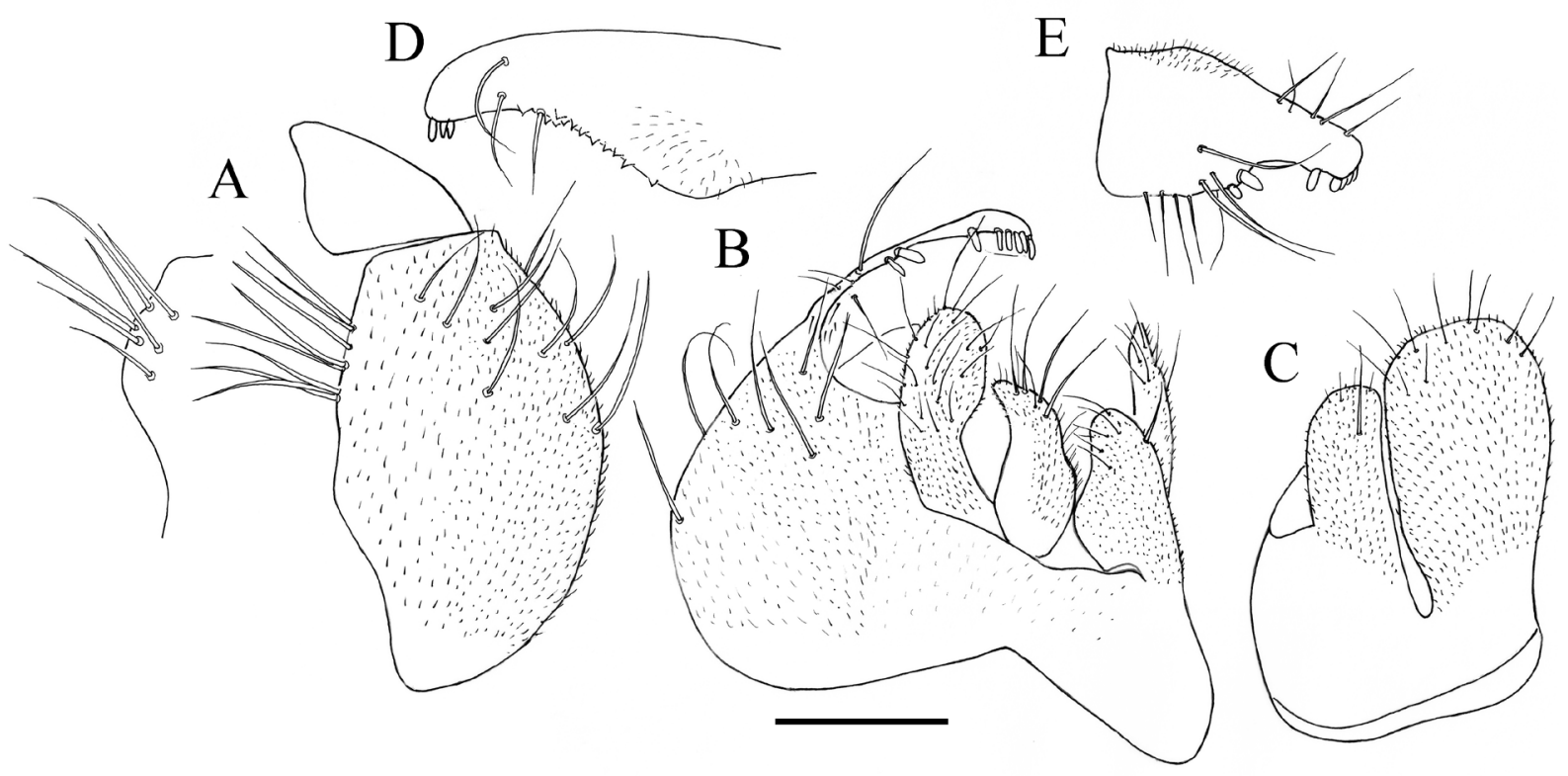

Fig. 14. Terminalia of Tachydromia stenoptera Gonçalves, Grootaert \& Andrade sp. nov., holotype (RBINS). A. Right surstylus and right epandrial lamella. B. Epandrium with cerci. C. Left epandrial lamella and left surstylus. D-E. Right surstylus. Scale bar: $0.1 \mathrm{~mm}$. 

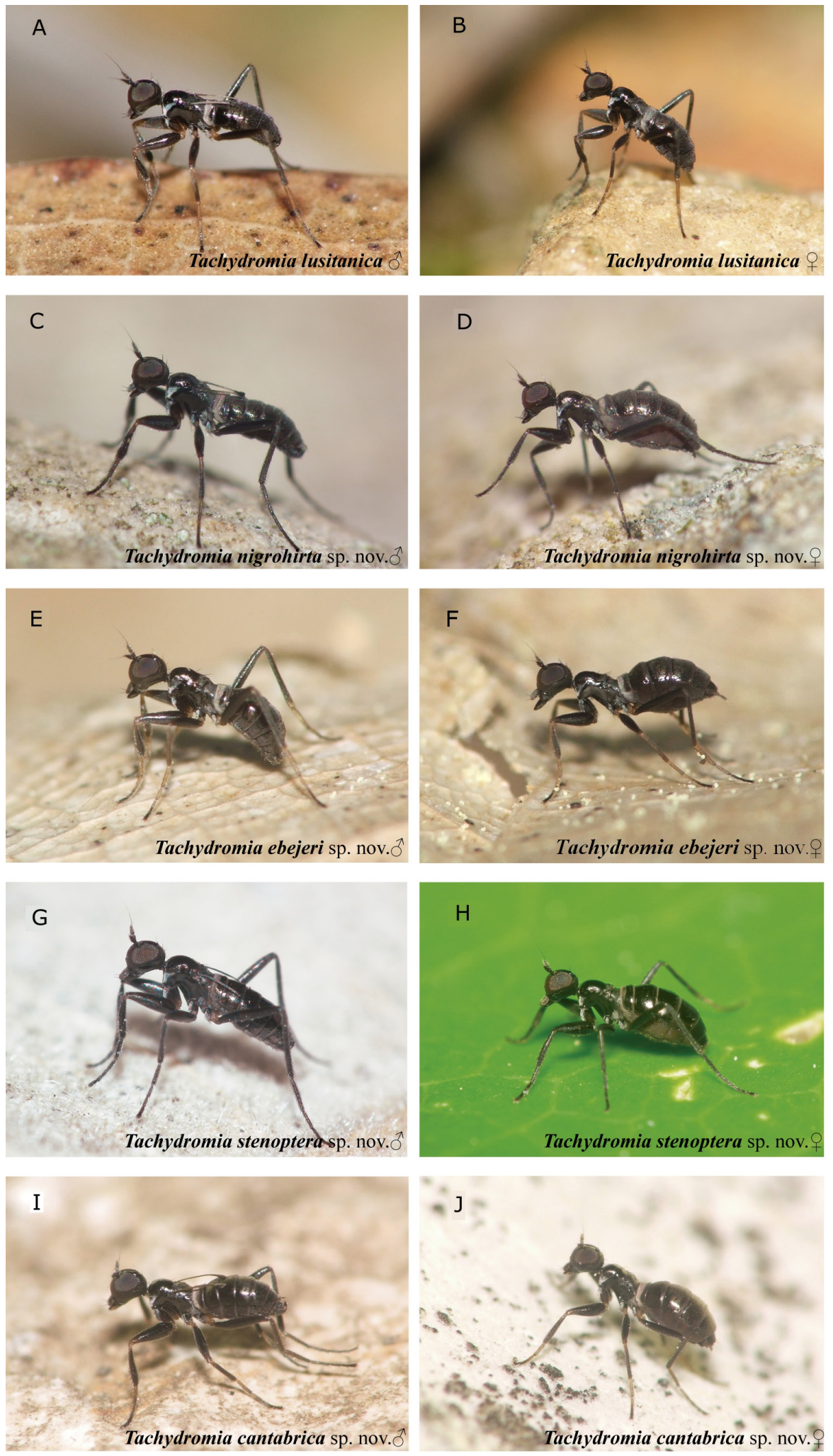

Fig. 15. Habitus of live specimens of the Iberian ant-like Tachydromia Meigen, 1803. Males are pictured in the left column, females in the right. A-B. T. lusitanica (Grootaert, Shamshev \& Andrade, 2009). C-D. T. nigrohirta Gonçalves, Grootaert \& Andrade sp. nov. E-F. T. ebejeri Gonçalves, Grootaert \& Andrade sp. nov. G-H. T. stenoptera Gonçalves, Grootaert \& Andrade sp. nov. I-J. T. cantabrica Gonçalves, Grootaert \& Andrade sp. nov. 

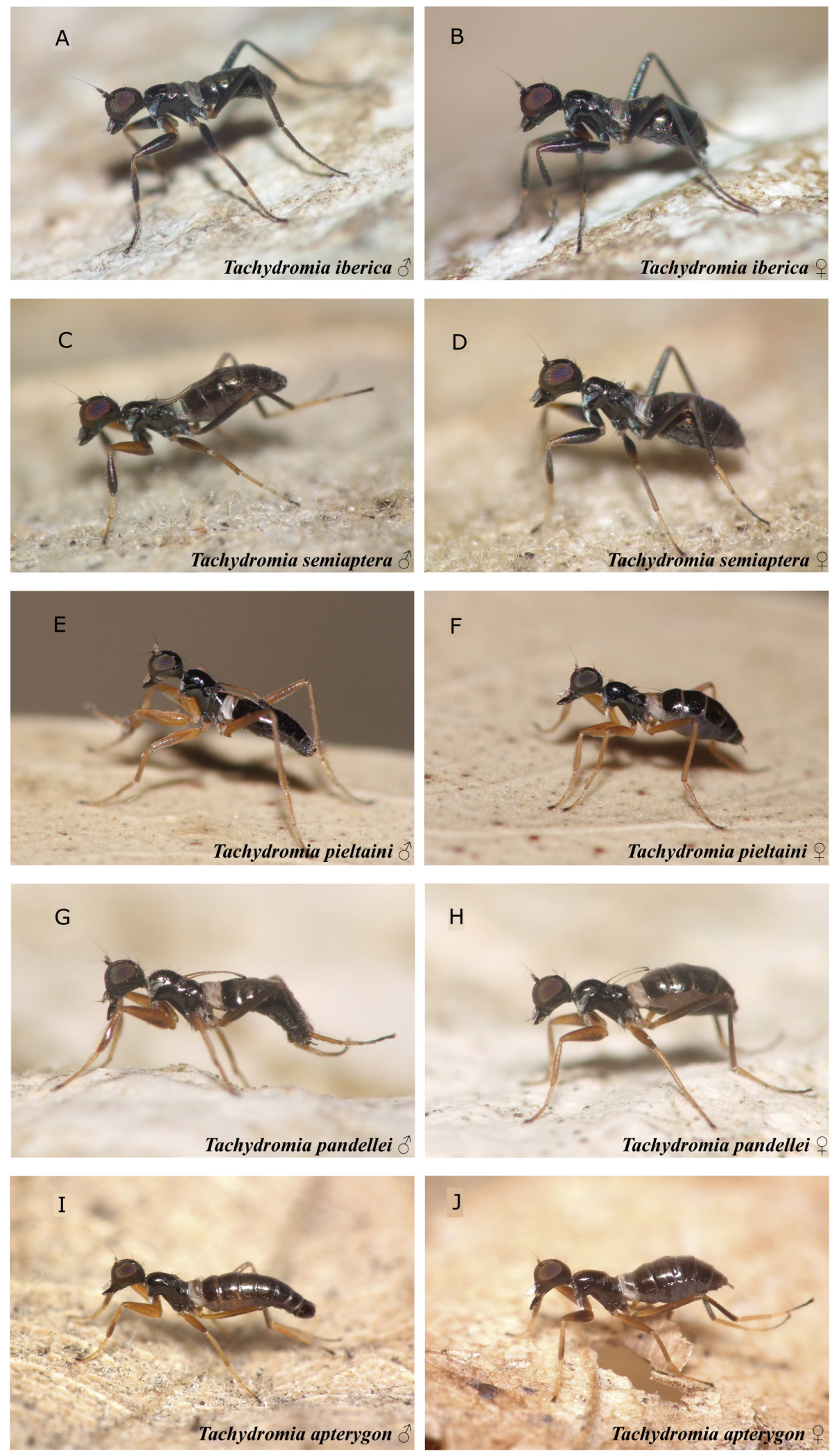

Fig. 16. Habitus of live specimens of the Iberian ant-like Tachydromia Meigen, 1803 and the Italian flightless Tachydromia. Males are pictured in the left column, females in the right. A-B. T. iberica (Arias, 1919). C-D. T. semiaptera (Gil Collado, 1923). E-F. T. pieltaini (Gil Collado, 1936). G-H. T. pandellei (Séguy, 1941). I-J. T. apterygon Plant \& Deeming, 2006 (Italy). 

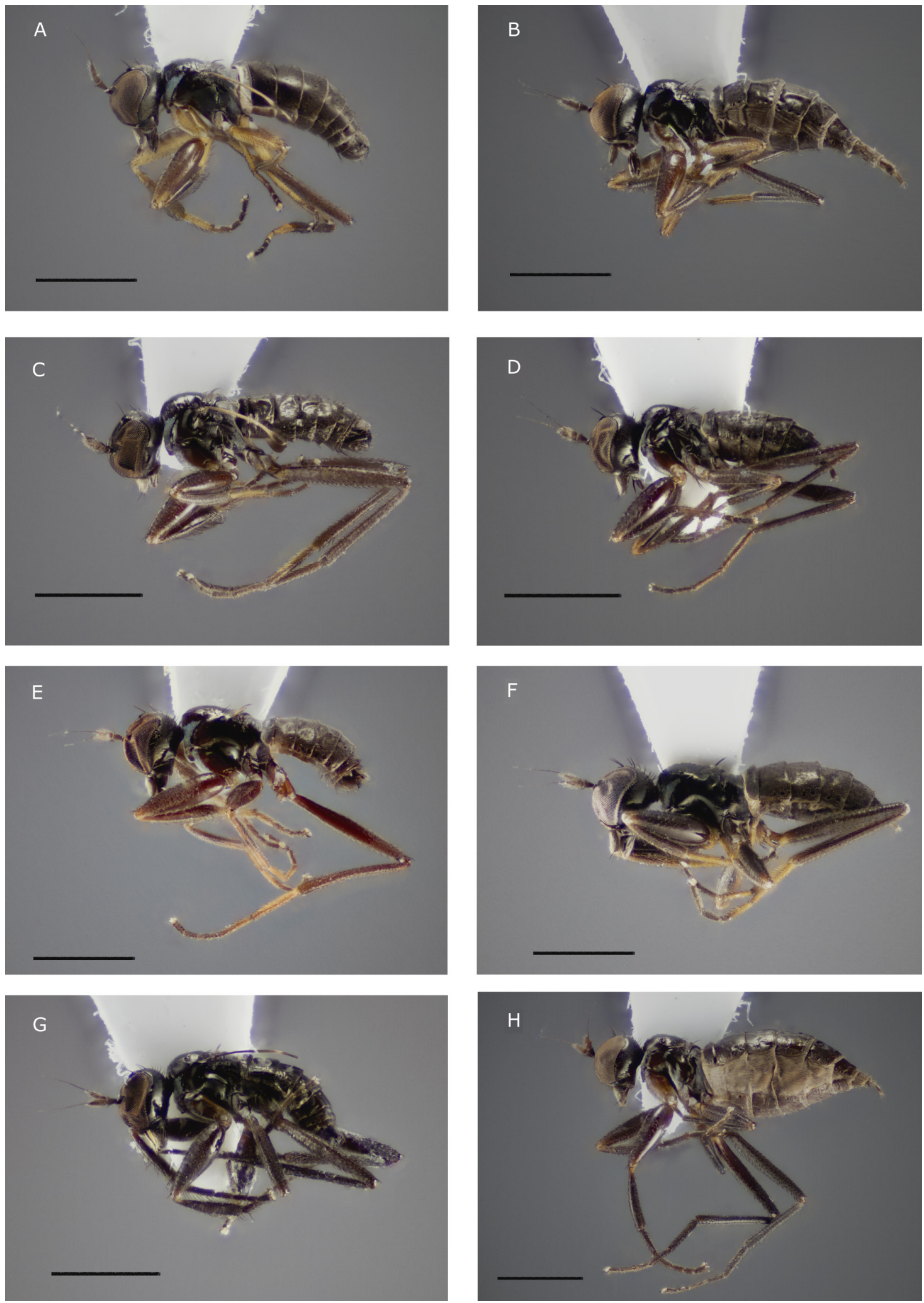

Fig. 17. Mounted specimens of the Iberian ant-like Tachydromia Meigen, 1803. Males are pictured in the left column, females in the right. A-B. T. lusitanica (Grootaert, Shamshev \& Andrade, 2009). C-D. T. nigrohirta Gonçalves, Grootaert \& Andrade sp. nov. E-F. T. ebejeri Gonçalves, Grootaert \& Andrade sp. nov. G-H. T. stenoptera Gonçalves, Grootaert \& Andrade sp. nov. Scale bars: $1 \mathrm{~mm}$. 

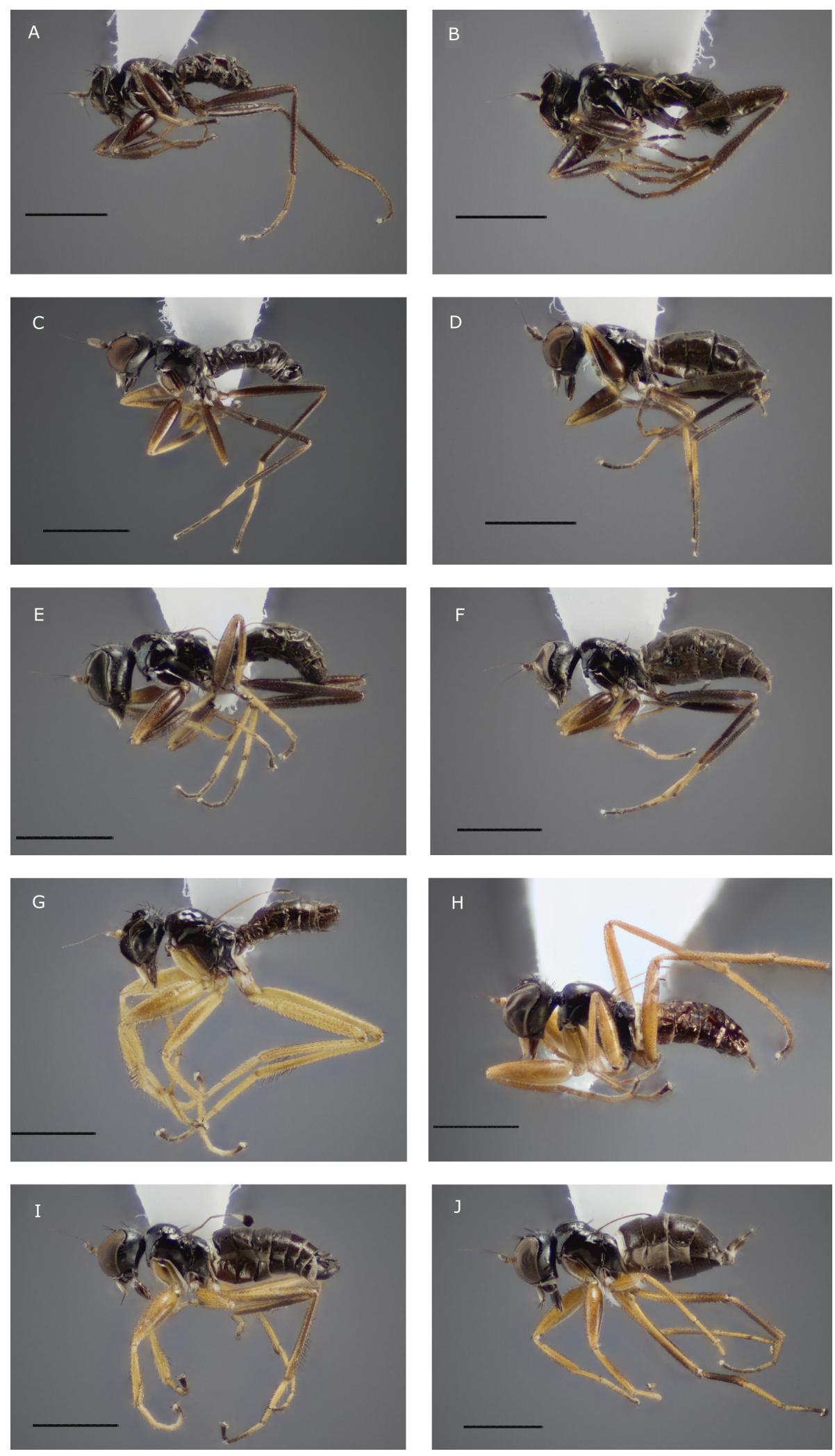

Fig. 18. Mounted specimens of the Iberian ant-like Tachydromia Meigen, 1803. Males are pictured in the left column, females in the right. A-B. T. cantabrica Gonçalves, Grootaert \& Andrade sp. nov. C-D. T. iberica (Arias, 1919). E-F. T. semiaptera (Gil Collado, 1923). G-H. T. pieltaini (Gil Collado, 1936). I-J. T. pandellei (Séguy, 1941). Scale bars: $1 \mathrm{~mm}$. 

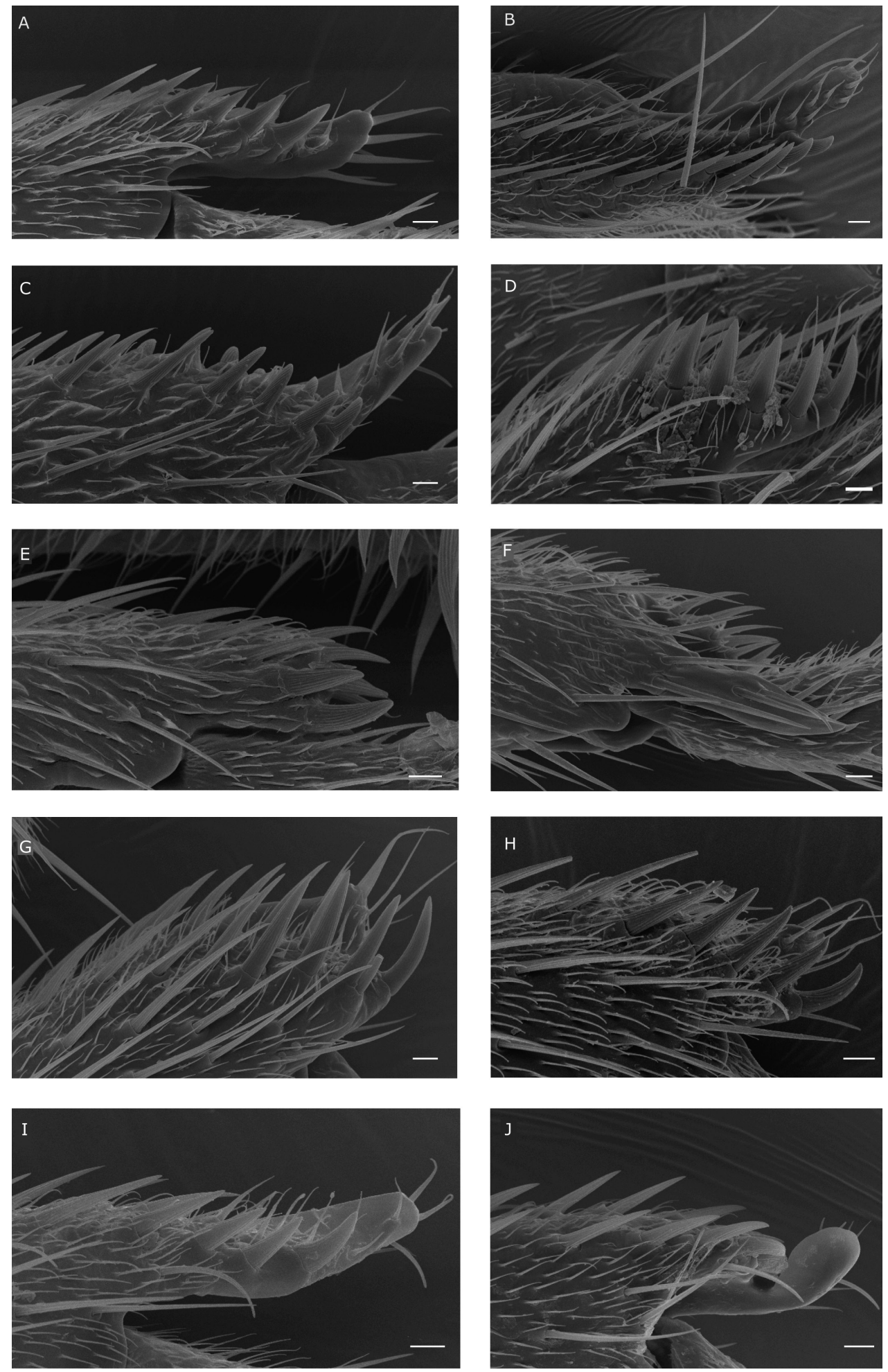

Fig. 19. Images obtained by scanning electron microscopy of the spur-like structures present on the apical portion of the male mid tibia. A. T. lusitanica (Grootaert, Shamshev \& Andrade, 2009). B. T. pandellei (Séguy, 1941). C. T. pieltaini (Gil Collado, 1936). D. T. ebejeri Gonçalves, Grootaert \& Andrade sp. nov. E-F. T. semiaptera (Gil Collado, 1923). G. T. stenoptera Gonçalves, Grootaert \& Andrade sp. nov. H. T. cantabrica Gonçalves, Grootaert \& Andrade sp. nov. I. T. nigrohirta Gonçalves, Grootaert \& Andrade sp. nov. J. T. apterygon Plant \& Deeming, 2006. Scale bars: $10 \mu \mathrm{m}$. 

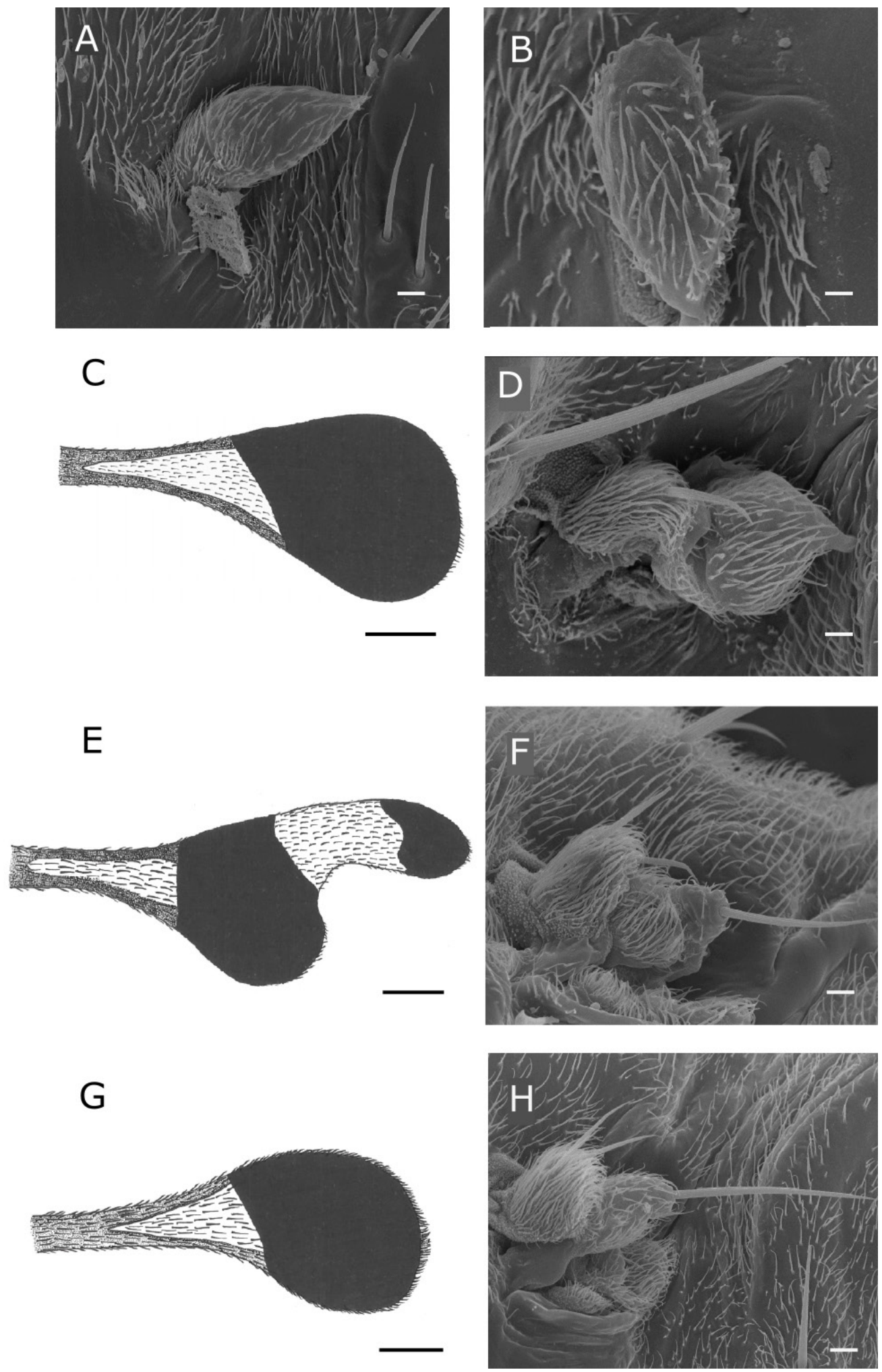

Fig. 20. Drawings of the tip of stenopterous wings and images obtained by scanning electron microscope (SEM) of the micropterous wings. Males are pictured in the left column, females in the right. A-B. T. ebejeri Gonçalves, Grootaert \& Andrade sp. nov. C-D. T. cantabrica Gonçalves, Grootaert \& Andrade sp. nov. E-F. T. lusitanica (Grootaert, Shamshev \& Andrade, 2009). G-H. T. nigrohirta Gonçalves, Grootaert \& Andrade sp. nov. Scale bars: A-B, D, F, H $=10 \mu \mathrm{m} ; \mathrm{C}, \mathrm{E}, \mathrm{G}=50 \mu \mathrm{m}$. 

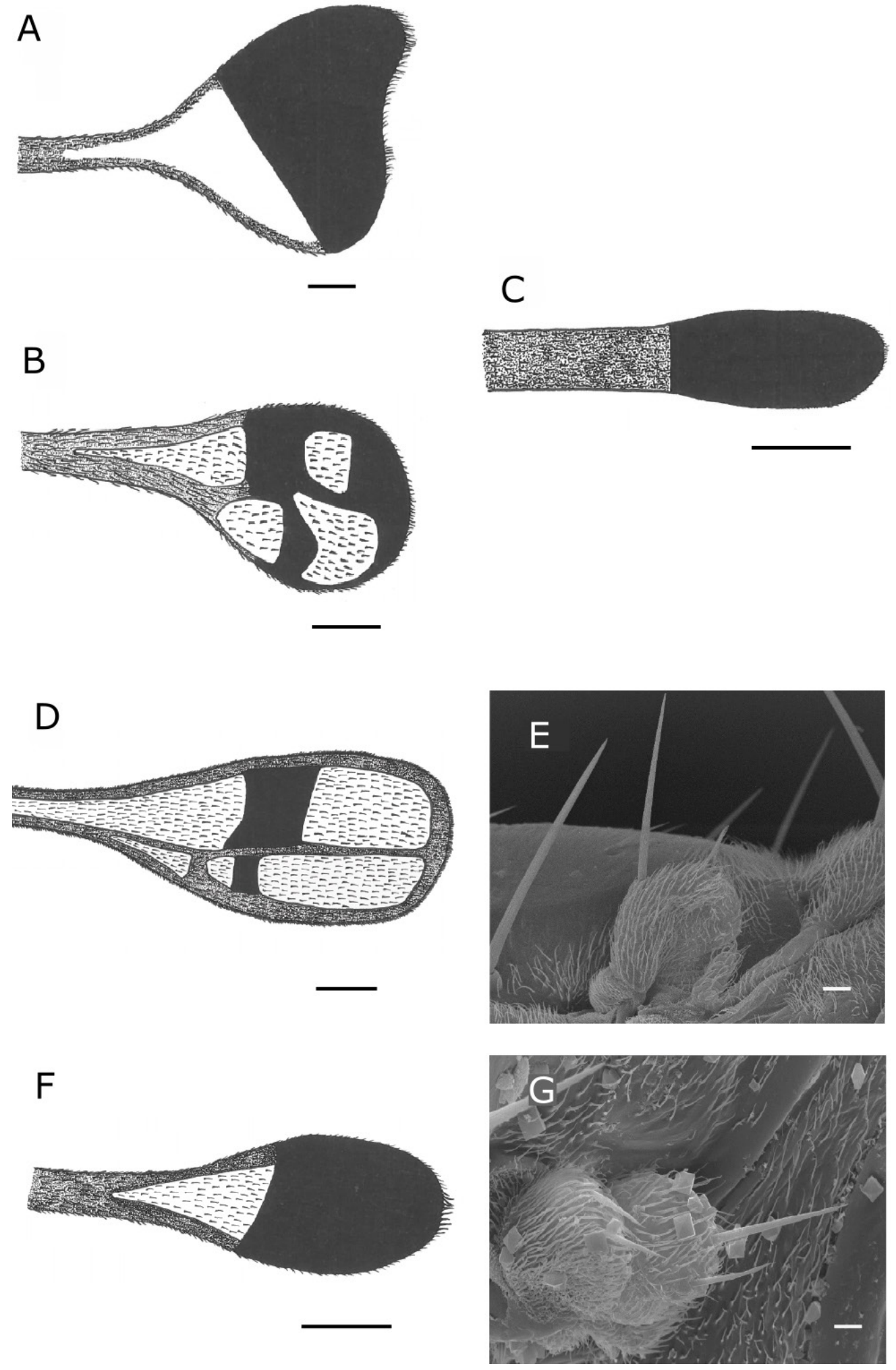

Fig. 21. Drawings of the tip of stenopterous wings and images obtained by scanning electron microscope (SEM) of the micropterous wings. Males are pictured in the left column, females in the right. A, C. T. pandellei (Séguy, 1941). B-C. T. pieltaini (Gil Collado, 1936). D-E. T. semiaptera (Gil Collado, 1923). F-G. T. stenoptera Gonçalves, Grootaert \& Andrade sp. nov. Scale bars: A-D, F = $50 \mu \mathrm{m}$; E, G $=10 \mu \mathrm{m}$. 
Terminalia (Fig. 14). Right epandrial lamella convex, globose. Right surstylus with several (ca 7) distinct denticle-like setae, mostly aggregated on distal margin. Right cercus longer than left, subcylindrical, left narrowing distally. Long setae of unequal length present on apical half of right cercus; long and stronger setae on apical margin of left cercus. Left epandrial lamella $2 / 3$ as long as left cercus. Left surstylus suboval 2 times as long as wide, longer than cerci.

\section{Female}

Similar to male, except for following features: micropterous, with wings round, brownish wings, bilobate, bearing two setae on apical margin of each lobe, covered by grey microtrichia (Fig. 21G); legs covered with regular rows of setae, with distinct apical setae on fore femur, without other distinctive setae; apical projection on mid tibia absent; cercus pale brown with grey microtrichia and setae; without longer setae on apical sternites.

\section{Distribution}

Portugal. Only known from the western end of the Iberian Central System. It has not yet been found in Spain, but given that it was found very close to the border, it is very likely that it will eventually be found in this country.

\section{Notes on habitat, distribution, and phenology}

The fieldwork yielded a significant amount of new data regarding both the geographic distribution of most species (Fig. 1) and their (micro)habitat. Currently, the following number of localities are known for each species: T. cantabrica sp. nov. is known from 3 localities, T. ebejeri sp. nov. from 23, T. lusitanica from 41, T. nigrohirta sp. nov. from 3, T. pandellei from 13, T. pieltaini from 5, T. semiaptera from 27 and T. stenoptera sp. nov. from 7. These species occur in temperate and sub-mediterranean regions, mainly in mountains, where they often inhabit forests dominated by deciduous or marcescent trees, such as Quercus robur L., Q. pyrenaica Willd. and Fagus sylvatica L. They are only to be found among the

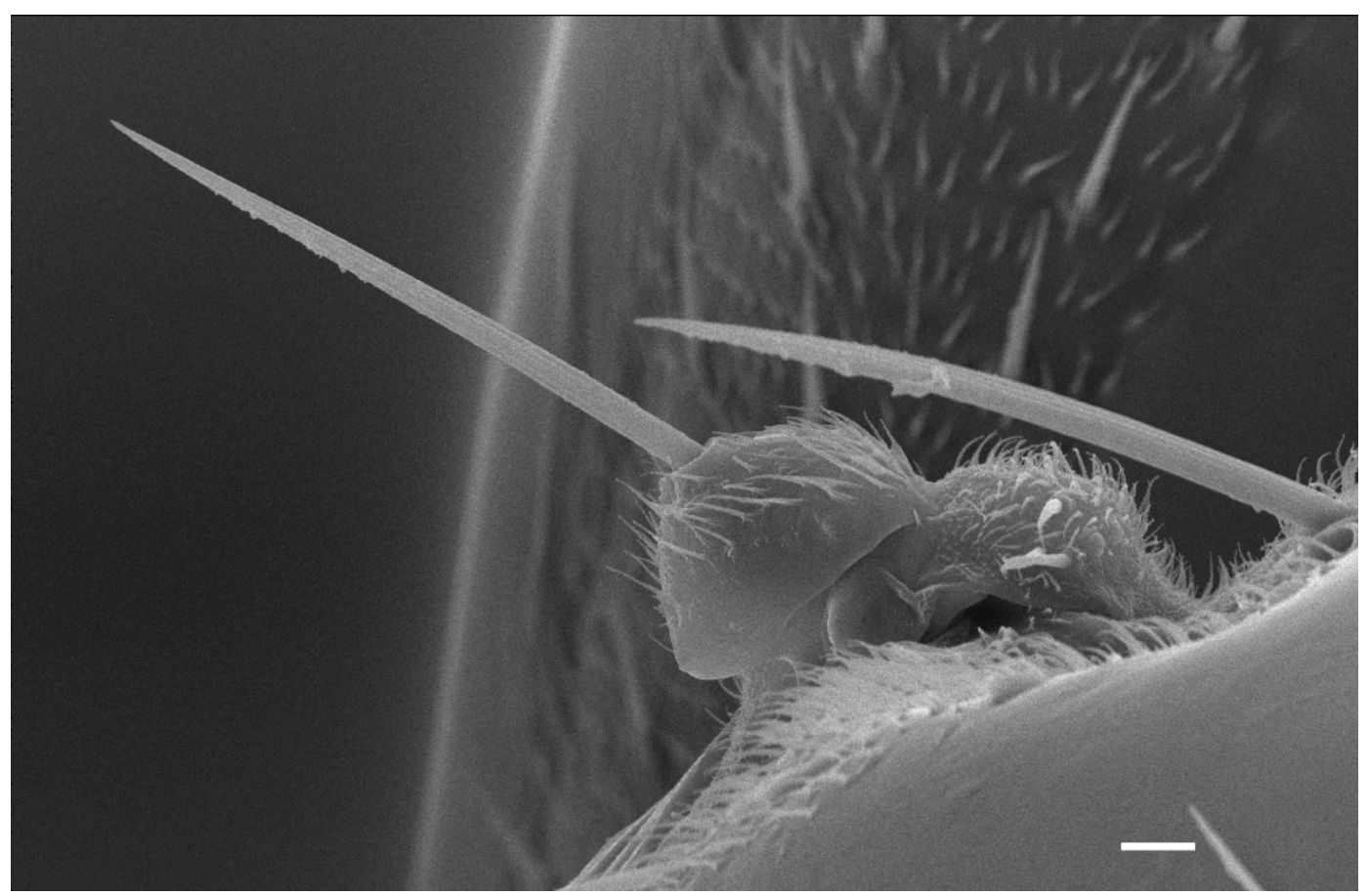

Fig. 22. Image obtained by scanning electron microscope (SEM) of the micropterous wing of a male of Tachydromia apterygon Plant \& Deeming, 2006. Scale bar: $10 \mu \mathrm{m}$. 
leaf litter and very low herbaceous vegetation. Furthermore, most Iberian ant-like Tachydromia tend to become active in early spring (mostly from February until May); however, species as T. pandellei and T. pieltaini only occur at higher altitude and, hence, become active much later in the year (likely May onwards). These species often occur in the forests of Fagus sylvatica but seem to be present only on the edge of the forest. The Iberian ant-like Tachydromia are often found among other flightless insects, especially ants, such as Lasius Fabricius, 1804. However, no direct predation on Tachydromia by ants was ever observed. The Tachydromia themselves seem to prey only on adult Sciaridae (fungus gnats) and Chironomidae (non-biting midges).

\section{Observations on mating behaviour of $\mathrm{T}$. semiaptera and $\mathrm{T}$. iberica}

Successful mating attempts have only been observed in both species when the male was in possession of a prey. The movements performed by a male interested in copulating, as described below, are the same even if it does not hold a prey, with the additional fact that he chases the female. Usually, the female attempts to steal the prey and either the male allows it and immediately mounts her or, showing no interest in copulating, flees away with the prey. In the last scenario, the male may, at most, briefly move its stretched abdomen vertically. In the case of T. iberica he also may move the mid legs sideways, as observed when he is confronted with another male or any perceived danger.

When the female approaches the male to steal the prey, the male interested in copulating stretches his abdomen and waves it up vertically but, additionally, moves his forelegs sideways. The male offers no resistance when the female takes the prey and, instead, readily mounts her back, beginning the mating

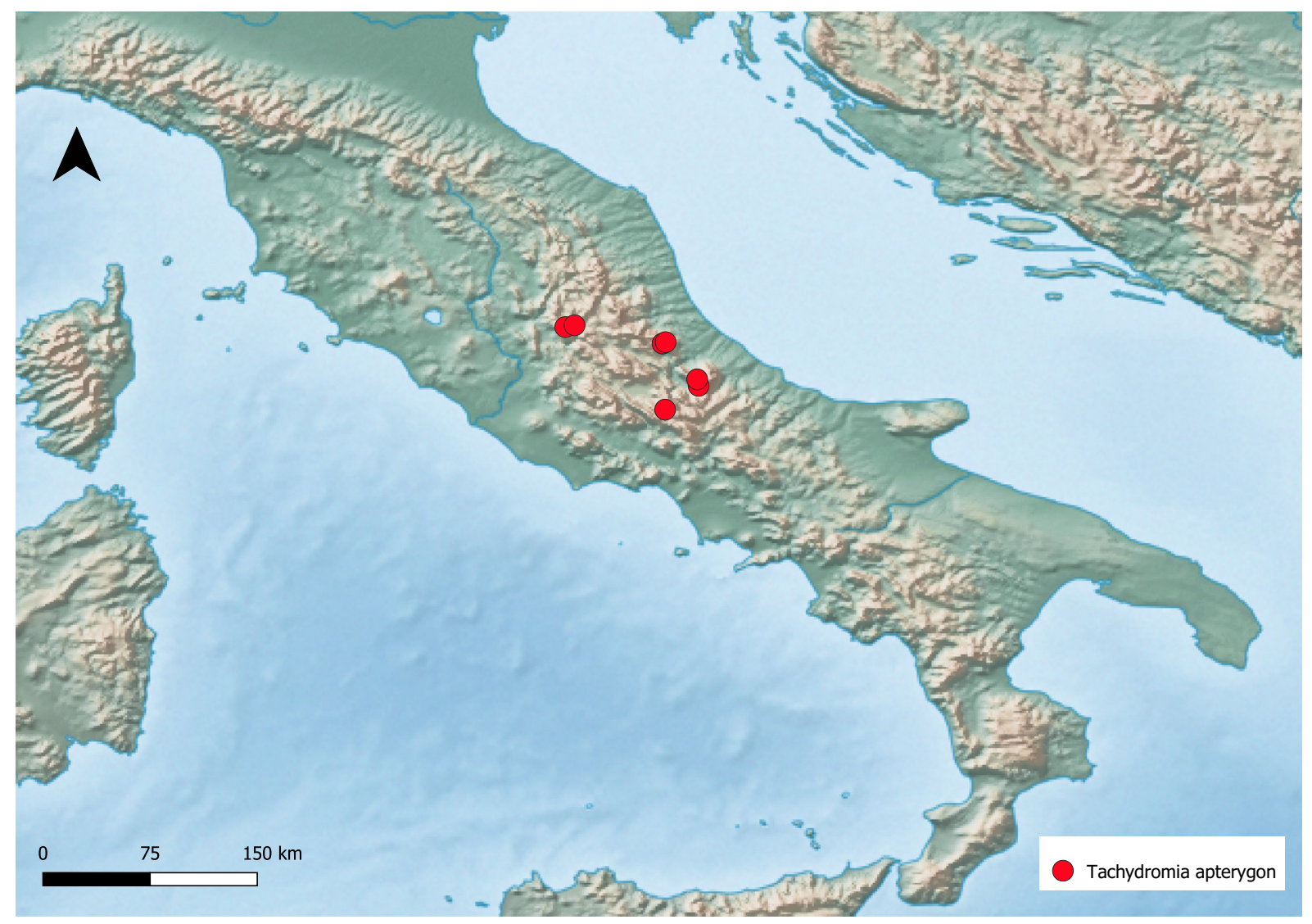

Fig. 23. Distribution of Tachydromia apterygon Plant \& Deeming, 2006 in Italy. Nine localities are currently known. 
attempt. Instantly, the male places his forelegs above the female's eye level, while the mid legs are placed in the female's waist in an attempt to grab it. At the beginning of the copula, the male moves his forelegs sideways at the female's eye level, while, with his posterior legs, rubs his own last tergite and twitches it. The movement of the forelegs is very similar to the movement of the wings described in T. lusitanica by Andrade (2011). When their genitalia seem to be locked, the male keeps himself very still, always with his forelegs above the female's eye level. The female then may move around, sometimes very fast, while keeping the prey with the male on top. Frequently, the male of T. iberica lets himself be carried around by the female in a tail-to-tail position. When the specimens disconnect, both individuals usually fight vigorously for the prey.

\section{Discussion}

\section{Phylogenetic relationships and systematics}

The phylogenetic relationships within Tachydromiinae have been studied previously, but mostly at the tribe and generic level (e.g., Nagy et al. 2013) with the specific diversity within the genus yet to be studied in further detail. This is the first time that all the Iberian and Italian ant-like species have been sequenced, and their phylogenetic relationship as well as the evolutionary relationships between every ant-like species and the genus Tachydromia analysed.

The inferred phylogenetic position of the type species of Ariasella as sister taxon to the remaining Ariasella species and Pieltainia supports the conclusion by Shamshev \& Grootaert (2018) that the absence of functional wings has no phylogenetic value at generic level. The placement of the two genera within the clade of Tachydromia corroborates their synonymy under Tachydromia.

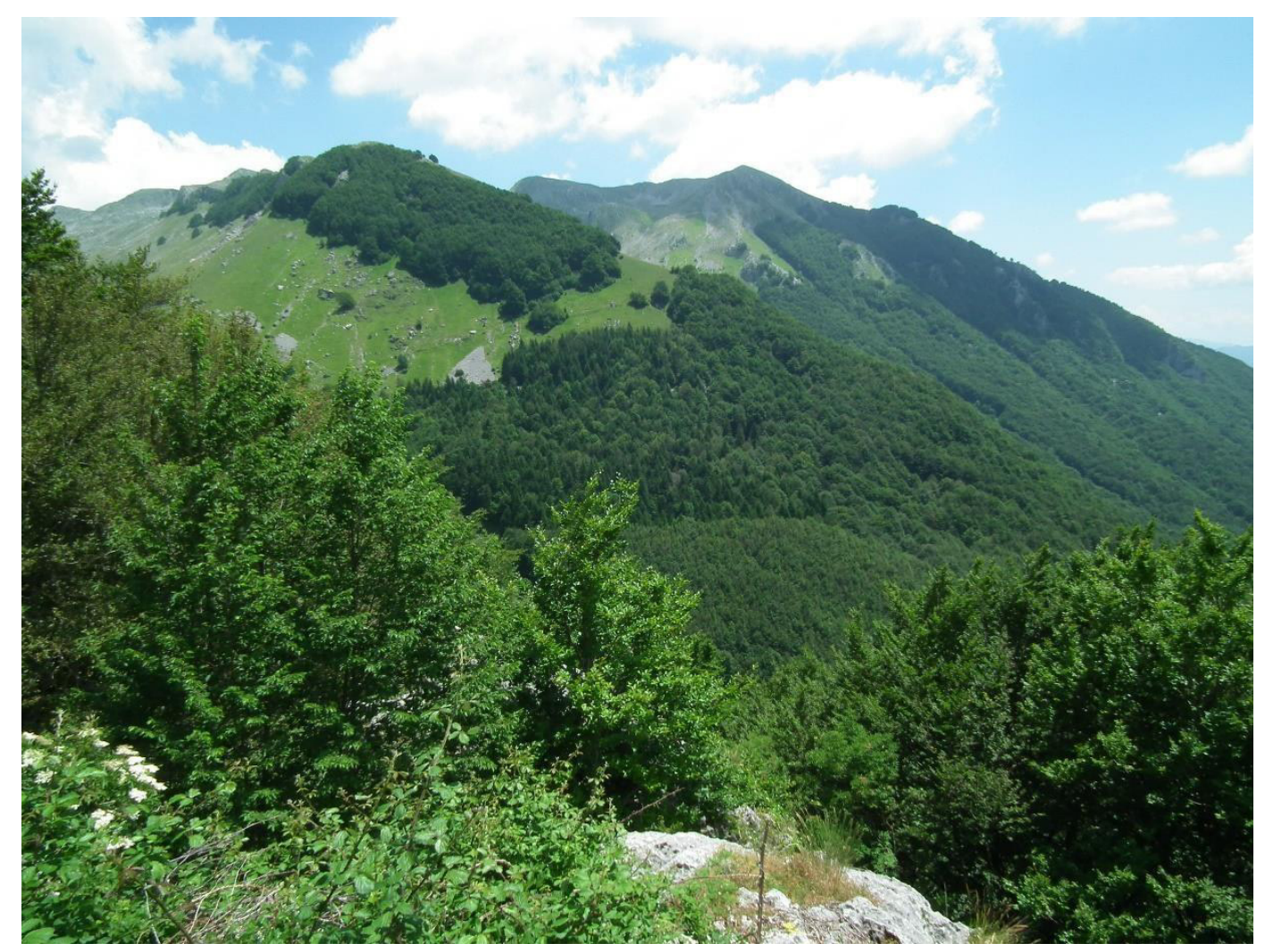

Fig. 24. Forest of Fagus sylvatica L. in the Apennine Mountains, where Tachydromia apterygon Plant \& Deeming, 2006 can be found. 
The Iberian ant-like species of Tachydromia form an evolutionary closely related group and the inferred phylogenetic relationships are in accordance with the morphological characters. Hence, T. semiaptera is resolved as the sister taxon to all other Iberian species as its peculiar morphology suggests. This taxon possesses a combination of characters in the male (i.e., two projections on mid tibia, lack of ciliation of long hairlike setae on the fore tibia, roundish postpedicel and flexible wing) that are not found in any other species. A spur-like structure (Fig. 19) on the mid tibia of the male is present in all Iberian and Italian species, apart from T. iberica, which completely lacks it. As described in the morphological analysis, this structure is, for most species, composed of a basal section bearing denticles and a side projection. In the case of T. semiaptera, the basal section and projection are totally separated or, at least, their separation is much deeper than in other species. To our knowledge, this is the only case in the genus Tachydromia where this deep or total separation occurs. Furthermore, this structure likely has a evolutionary relevance, as the males of the species in which mating was observed, grab the females by using the mid legs.

Tachydromia iberica is a species that lacks many of the characters with taxonomic relevance found in other species as it is apterous in both sexes, does not have spur-like structures or characteristic setae (e.g., ciliation of long hair-like setae on the fore tibia). Some differences at the terminalia, mainly concerning the right surstylus, were found among three geographically distant populations. However, these differences are of degree rather than regarding the basic form and have less taxonomic relevance.

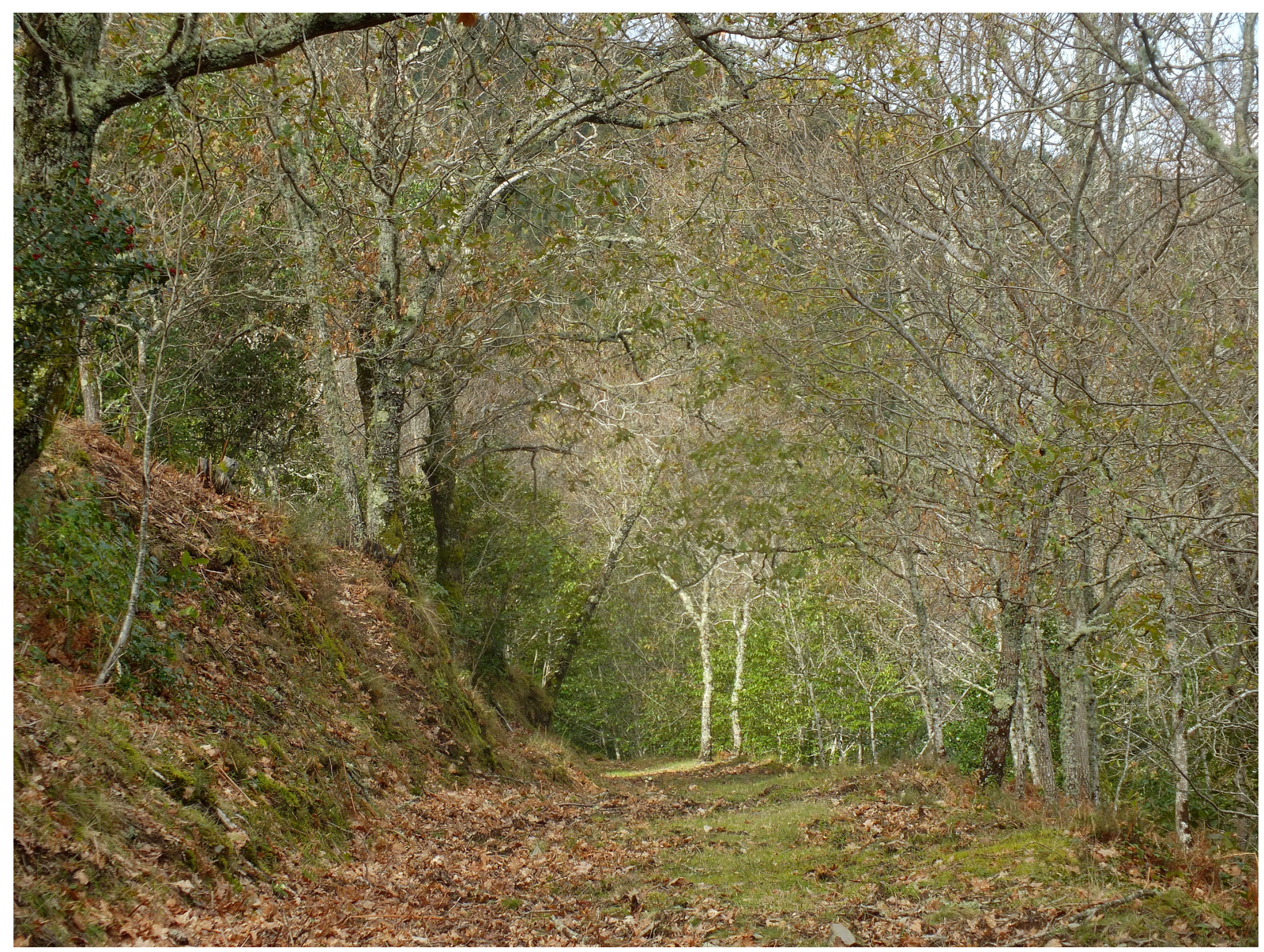

Fig. 25. Habitat of Tachydromia ebejeri Gonçalves, Grootaert \& Andrade sp. nov. in a forest of Quercus pyrenaica Willd. in Portugal, Arganil, Benfeita (Mata da Margaraça), a region under submediterranean influence. 
Additionally, the specimens sequenced are still very much related as recovered in the phylogenetic analysis, where they are separated by short branches.

Furthermore, and even though we conducted a total evidence phylogenetic analysis, it seems relevant to comment on the COI p-divergences as this gene is often used to distinguish species, despite some recognized issues (e.g., Meier et al. 2006). While the genetic diversity at species level within Hybotidae remains scarcely studied, large intraspecific COI p-divergences are not uncommon in Hybotidae (see Nagy et al. 2013). In the mentioned study, for example, an intraspecific divergence of up to $5.48 \%$ was found within the studied Tachydromia. In the specific case of T. iberica, the high divergence found at interpopulational level (4-5\%) may be representative of vicariance processes, especially as no significant morphological or ecological differences were found to substantiate the separation of the populations as distinct species.

Concerning the sister-species T. pieltaini and T. pandellei, these two species are morphologically similar but with very clear differences that allow for a straightforward species separation. In this case, the two more relevant characters are perhaps the wing pattern and shape as well as the terminalia (in males), which are very different. These morphological differences are highly congruent with the molecular data, as these species are separated by relatively long branches in the inferred phylogenetic tree.

The four newly described species all belong to the same cluster where T. lusitanica was resolved. With the exception of the micropterous T. ebejeri sp. nov., the male wing, in this species cluster, is stenopterous with his lobed tip divided into a white/transparent basal portion and black distally, but it is in T. lusitanica where it presents a more remarkable shape by bearing a distal projection. Tachydromia nigrohirta sp. nov. was inferred as a sister taxon to T. lusitanica and this pair has less morphological differences in comparison with, for example, T. pieltaini and T. pandellei. There is not enough phylogenetic signal in the studied molecular markers to fully resolve the relationships between T. stenoptera sp. nov., $T$. cantabrica sp. nov. and T. ebejeri sp. nov., which may be a result from a rapid speciation process.

Regarding the placement of the Iberian ant-like species within the species groups previously defined for Tachydromia, it is possible to associate them more closely with the arrogans species group, although this association is uncertain due to the lack of developed wings and other morphological characteristics which do not fit into the group definition, such as the shorter stylus and/or the large and globular male genitalia. The overall morphology - despite the lack of developed wings - places the Italian Tachydromia apterygon within the terricola species group, as suggested by Plant \& Deeming (2006). However, the molecular data clearly places it as being more closely related to the arrogans species group. Therefore, further molecular studies are necessary to understand the phylogenetic relationships of T. apterygon and the monophyly of the suggested Tachydromia species groups based on morphological data.

Concerning the slight differences of the support values between the trimmed and nontrimmed datasets, we assume that both RECs and RSCs have some effect on the branch support values, not on the topology as primarily thought. In our results, the inferred topology using the trimmed version of the $28 \mathrm{~S}$ alignment receives, overall, slightly lower support values than the non-trimmed, indicating that the ambiguous regions of the $28 \mathrm{~S}$ gene provides some support for the best tree.

A hypothesis on the evolution of these species can be proposed based on the recovered phylogenetic relationships and knowledge about the behaviour and habitat. While the divergence events are not dated, the short internodes in the cluster of the Iberian Tachydromia may very well reflect a rapid succession of splitting processes. It is possible that geographically separated populations adapted differently to similar ecological conditions, hence simultaneously evolving different sexual signalling strategies. Thus, differences may have arisen following vicariance processes and now these species show distinct behaviours and life histories, which may block the gene flow between them in sympatry. 


\section{Wing reduction/modification in Tachydromia and its evolutionary significance}

As mentioned before, the lack of functional wings is a common phenomenon in Diptera and several hypotheses for flightlessness in insects have been discussed, including habitat persistence and cryptic behaviours (Hackman 1964). Roff (1990) concluded that the loss of wings is common in spatially and temporally homogeneous environments and that there is considerable evidence for an increase in flightlessness with altitude. The Iberian ant-like species are mostly present on mountains and in deciduous forests, which are known to be stable habitats (Roff 1990), their microhabitat being restricted to the leaf litter. Overall, the evolution of flightlessness in Tachydromia is currently known from 13 species (including the Iberian and Italian taxa), out of some 100 described species. It is expected that more cases may be discovered, especially if field work is carried out at high altitude in temperate cold environments. Regarding the evolution of the wings in the Iberian ant-like Tachydromia, we hypothesize that two processes may have taken place: one is the wing reduction itself, which may happen in both sexes, and another is the wing modification with a sexual signalling function, which only happens in the male. Therefore, in some species only wing reduction to different degrees occurred, from the stenopterous species to the apterous, with the micropterous inbetween. In certain cases, the female is stenopterous without a distinct lobed tip on its wing, while the male wing has a very distinct and large lobed tip (see: Tachydromia pieltaini, Tachydromia pandellei, Fig. 21A-C). However, more commonly, a more distinct sexual dimorphism is present, where the female is micropterous and the male is stenopterous.

It is interesting that the sexual signalling process does not happen the same way in all species, as observed in the mating behaviour of $T$. semiaptera. Contrary to T. lusitanica, the male of this species does not wave its wings during copula, nor do the wings seem to have any other function. Moreover, its wings are much less rigid than the ones of all the remaining related species, so it is possible that the stiffness of the stalk-like portion of the wing is an important part of the wing modification process, making them easier to wave. Hence, while the wings of the stenopterous species may look similar at first glance, they actually differ in their morphology and might have different functions.

In T. semiaptera only a process of wing reduction seems to be taking place. Nonetheless, this species has a very distinct feature, which has the same signalling function as that of the wing in $T$. lusitanica. Its fore tibia - which is black, stout and inflated - is waved in front of the female's eyes during copula. A similar signalling method is used by T. iberica (waving the forelegs) but this species, instead of a modified tibia, simply has a yellow and black foreleg. Furthermore, both species lack the ciliation of hair-like setae on the male foreleg, present in T. lusitanica, whose forelegs were observed to intertwine with those of the female (Andrade 2011). This behaviour was not observed in T. semiaptera or T. iberica.

Taking all information into account, at least in the case of $T$. lusitanica, wing reduction seems to be coupled with an important modification of sexual relevance, and it appears that both ecological and sexual pressures are driving its evolution. Similar situations are likely to be present in the other species that show a distinct sexual dimorphism in the wing morphology, but this remains to be tested.

\section{Remarks on the habitat and distribution with implications on conservation}

As previously mentioned, the ant-like species of Tachydromia occur in regions of temperate and submediterranean bioclimatic influence. In these bioclimates, the potential natural vegetation is composed of broad-leaved deciduous or marcescent species and, often, the forests are dominated by oak trees, such as Quercus robur L. and Quercus pyrenaica Willd (Fig. 25) (Costa et al. 2005). At higher altitude, the oak trees are substituted by Fagus sylvatica L., a deciduous tree that forms monospecific stands with a closed canopy, which blocks the penetration of sunlight and creates very shaded environments (Costa et al. 2005). The soil of these deciduous and marcescent forests tends to have a deep layer of leaf litter. This layer of leaf litter, with some degree of light penetration, high humidity and rich in organic matter, 
is the typical microhabitat where ant-like Tachydromia can be found. With the exception of the species occurring at high altitude, the adults of Iberian ant-like Tachydromia become active at the beginning of the spring, when the trees are still without leaves, and the sunlight can directly reach the ground. The flies can then be found both inside the forest and along the forest edge.

Tachydromia pandellei and T. pieltaini often occur in habitats where the forest is often dominated by Fagus sylvatica, and they probably only live along the edge of the forest because it provides the presence of leaf litter combined with higher light penetration than microhabitats under dense canopy. The leaf litter itself is a humid, stable environment and likely offers shelter from predators and the weather elements (e.g., wind, rain). It is also the habitat for prey, as these species mainly feed on saprophilous flies that are dependent on organic matter.

In general, at a macroclimatic scale, the ant-like species of Tachydromia seem to have relatively similar ecological requirements and some species do co-occur in the same habitats (Fig. 2). This is, for example, the case of T. semiaptera, which co-occurs with T. ebejeri sp. nov., T. nigrohirta sp. nov. and T. iberica. However, T. semiaptera seems to become active later in the year than T. ebejeri sp. nov. and T. nigrohirta sp. nov., and does not overlap at a temporal scale with T. ebejeri sp. nov. in the same habitats. We suspect that further fieldwork likely will increase the geographic ranges reported for most species, especially of T. semiaptera, T. cantabrica sp. nov., T. pandellei and T. pieltaini. However, given the previous sampling efforts, T. stenoptera sp. nov. and T. nigrohirta sp. nov. appear to be genuinely restricted to a smaller area of occurrence.

Most populations of the Iberian ant-like Tachydromia exist in highly fragmented landscapes given their occurrence in temperate and humid forested habitats. This is especially true for the species with populations in the southern half of the Iberian Peninsula, where they are circumscribed to small submediterranean bioclimatic islands surrounded by a dry and hot environment. This is the case for the southernmost populations of T. iberica, T. semiaptera and T. ebejeri sp. nov., but even the populations in the northern regions occur in fragmented habitats. The habitat fragmentation is often caused by disturbances of anthropogenic origin, such as the artificialization of the land, agricultural intensification, substitution of the natural vegetation by monocultures and invasive species, as well as induced fires. The climate is also expected to become warmer, greatly reducing the area occupied by temperate and submediterranean trees, as Querqus robur and Q. pyrenaica (Benito Garzón et al. 2008). Climate change, coupled with habitat fragmentation, will almost certainly imperil the conservation of the Iberian ant-like species of Tachydromia.

\section{Acknowledgements}

The authors would like to thank everyone who has provided us with very important help finding suitable areas to prospect, for support during field work and/ or by collecting specimens, namely: Piluca Álvarez, Rafael Obregón, Francisco Barros, Sam Martins, Pedro Andrade, Diana Rodrigues, Isaías Ferreira, Carlos Silva, Jorge Almeida, Ádria Miralles, Carlos Vila-Viçosa, Eduardo Marabuto, Martin J. Ebejer, Ruud van der Weele, Alice Abela, Nigel Jones, Jorge Rosete and Sérgio Henriques. We would also like to thank Eduardo Marabuto for providing support on studying the evolution, conservation and taxonomy of these species. We would like to thank Telmo Martins for his vital help with obtaining the SEM images (imaging and analysis done at the Faculty of Sciences of the University of Lisbon's Microscopy Facility, a node of the Portuguese Platform for BioImaging, reference PPBI-POCI-01-0145FEDER-022122). A special gratitude is due to Claudia Etzbauer for teaching and helping the first author in the laboratory. We would also like to thank the reviewers for their important comments to highly improve the manuscript. Part of the fieldwork was supported by the Systematics Research Fund from the Systematics Association and the Linnean Society of London. 


\section{References}

Andrade R. 2011. Observations on the behaviour of Ariasella lusitanica, Grootaert et al., 2009 (Diptera, Hybotidae, Tachydromiinae) from Portugal. Bulletin de la Société royale belge d'Entomologie 147: 241-250.

Arias J. 1919. Descripción preliminar de un nuevo Émpido de España. Boletin de la Real Sociedad Española de Historia Natural 19: 479-481.

Benito Garzón M., Sánchez de Dios R. \& Sainz Ollero H. 2008. Effects of climate change on the distribution of Iberian tree species. Applied Vegetation Science 11: 169 178. https://doi.org/10.3170/2008-7-18348

Bertone M.A., Courtney G.W. \& Wiegmann B.M. 2008. Phylogenetics and temporal diversification of the earliest true flies (Insecta: Diptera) based on multiple nuclear genes. Systematic Entomology 33 (4): 668-687. https://doi.org/10.1111/j.1365-3113.2008.00437.x

Chvála M. 1970. Revision of Palaearctic species of the genus Tachydromia Meig. (= Tachista Loew) (Diptera, Empididae). Acta Entomologica Musei Nationalis Pragae 38 (1969): 415-524.

Chvála M. 1975. The Tachydromiinae (Dipt. Empididae) of Fennoscandia and Denmark. Fauna Entomologica Scandinavica 3: 1-336.

Costa M., Morla C. \& Sainz H. 2005. Los Bosques Ibéricos: Una Interpretación Geobotánica. $4^{\text {th }}$ edition. Editorial Planeta, Barcelona.

Cumming J.M. \& Wood D.M. 2017. Adult morphology and terminology. In: Kirk-Spriggs A. \& Sinclair B.J. (eds) Manual of Afrotropical Diptera 1: 112. South African National Biodiversity Institute, Cape Town

Darriba D., Taboada G.L., Doallo R. \& Posada D. 2012. jModelTest 2: more models, new heuristics and parallel computing. Nature Methods 9: 772. https://doi.org/10.1038/nmeth.2109

Folmer O., Black M., Hoeh W., Lutz R. \& Vrijenhoek R. 1994. DNA primers for amplification of mitochondrial cytochrome c oxidase subunit I from diverse metazoan invertebrates. Molecular Marine Biology and Biotechnology 3: 294-299.

Gibson J.F., Kelso S., Jackson M.D., Kits J.H., Miranda G.F. \& Skevington J.H. 2011. Diptera-specific polymerase chain reaction amplification primers of use in molecular phylogenetic research. Annals of the Entomological Society of America 104 (5): 976-997. https://doi.org/10.1603/AN10153

Gil J. 1923. Estudio de un nuevo Taquidromino de España. Boletín de la Real Sociedad Española de Historia Natural 1923: 150-154.

Gil J. 1936. Una nueva especie del género Ariasella Gil, con breves consideraciónes sobre la reduccion del tórax en los Taquidrominos ápteros. Eos (Revista Española de Entomologia) 11 (3): 191-201.

Grootaert P. \& Shamshev I. 2008. Notes on the halobiont genus Chersodromia (Diptera: Hybotidae) from Tunisia with the description of a new brachypterous species and notes on brachyptery in empidoids. Bulletin de la Société royale belge d'Entomologie 144: 57-63.

Grootaert P., Shamshev I. \& Andrade R. 2009. Description of a new brachypterous Ariasella Gil (Diptera, Hybotidae, Tachydromiinae) from Portugal. Bulletin de la Société royale belge d'Entomologie 145: 45-48.

Hackman W. 1964. On reduction and loss of wings in Diptera. Notulae Entomologicae 44: 73-93.

Huelsenbeck J.P. \& Ronquist F. 2001. MrBayes: Bayesian inference of phylogenetic trees. Bioinformatics 17: 754-755. https://doi.org/10.1093/bioinformatics/17.8.754

Jemu. 2011. D1.Ft. Available from http://jemu.myspecies.info/d1ft [accessed 20 Sep. 2017]. 
Katoh K. \& Standley D.M. 2013. MAFFT multiple sequence alignment software version 7: improvements in performance and usability. Molecular Biology and Evolution 30 (4): 772-780.

https://doi.org/10.1093/molbev/mst010

Katoh K., Kuma K., Toh H. \& Miyata T. 2005. MAFFT version 5: improvement in accuracy of multiple sequence alignment. Nucleic Acids Research 33 (2): 511-518. https://doi.org/10.1093/nar/gki198

Katoh K., Asimenos G. \& Toh H. 2009. Multiple alignment of DNA sequences with MAFFT. In: Posada D. (ed.) Bioinformatics for DNA Sequence Analysis. Methods in Molecular Biology 537: 39-64. https://doi.org/10.1007/978-1-59745-251-9_3

Kjer K.M. 1995. Use of rRNA secondary structure in phylogenetic studies to identify homologous positions: an example of alignment and data presentation from the frogs. Molecular Phylogenetics and Evolution 4 (3): 314-330. https://doi.org/10.1006/mpev.1995.1028

Kjer K.M., Roshan U. \& Gillepie J.G. 2009. Structural and evolutionary considerations for multiple sequence alignment of RNA, and the challenges for Algorithms that ignore them. In: Rosenberg M.S. (ed.) Sequence Alignment: Methods, Models, Concepts, and Strategies: 105-150. University of California Press, USA.

Kumar S., Stecher G. \& Tamura K. 2016. MEGA7: Molecular Evolutionary Genetics Analysis Version 7.0 for Bigger Datasets. Molecular Biology and Evolution 33: 1870-1874.

https://doi.org/10.1093/molbev/msw054

Meier R., Shiyang K., Vaidya G. \& Ng P.K.L. 2006. DNA barcoding and taxonomy in Diptera: a tale of high intraspecific variability and low identification success. Systematic Biology 55: 715-728. https://doi.org/10.1080/10635150600969864

Miller M.A., Pfeiffer W. \& Schwartz T. 2010. Creating the CIPRES Science Gateway for inference of large phylogenetic trees. In: Proceedings of the Gateway Computing Environments Workshop (GCE): $1-8$. New Orleans.

Nagy Z.T., Sonet G., Mortelmans J., Vandewynkel C. \& Grootaert P. 2013. Using DNA barcodes for assessing diversity in the family Hybotidae (Diptera, Empidoidea). ZooKeys 365: 263-278. https://doi.org/10.3897/zookeys.365.6070

NCBI Resource Coordinators. 2016. Database resources of the National Center for Biotechnology Information. Nucleic Acids Research 44 (D1): D7-D19. https://doi.org/10.1093/nar/gkv1290

Plant A.R. \& Deeming J.C. 2006. An apterous species of Tachydromia Meigen, 1803 (Diptera: Hybotidae) from Italy. An International Journal of Dipterological Research 17 (1): 13-16.

Posada D. \& Buckley T. 2004. Model selection and model averaging in phylogenetics: advantages of Akaike information criterion and Bayesian approaches over likelihood ratio tests. Systematic Biology 53 (5): 793-808. https://doi.org/10.1080/10635150490522304

Rambaut A. 2009. FigTree: Tree Figure Drawing Tool. Version 1.3.1.

Available from http://tree.bio.ed.ac.uk/software/figtree/ [accessed 30 Nov. 2020].

Regier J.C., Shultz J.W., Ganley A.R., Hussey A., Shi D., Ball B., Zwick A., Stajich J.E., Cummings M.P., Martin J.W. \& Cunningham C.W. 2008. Resolving arthropod phylogeny: Exploring phylogenetic signal within $4 \mathrm{~kb}$ of protein-coding nuclear gene sequence. Systematic Biology 57: 920-938. https://doi.org/10.1080/10635150802570791

Roff D.A. 1990. The evolution of flightlessness in insects. Ecological Monographs 60: 389-421. https://doi.org/10.2307/1943013 
Roháček J. 2012. Wing polymorphism in European species of Sphaeroceridae (Diptera). Acta Entomologica Musei Nationalis Pragae 52 (2): 535-558.

Ronquist F. \& Huelsenbeck J.P. 2003. MrBayes 3: Bayesian phylogenetic inference under mixed models. Bioinformatics 19: 1572-1574. https://doi.org/10.1093/bioinformatics/btg180

Séguy E. 1941. Étude sur un nouveau Corynétine des Pyrénées. Bulletin de la Société entomologique de France 46: 4-6.

Shamshev I.V. \& Grootaert P. 2018. Proposed changes in systematics and status of some genera of Tachydromiini (Diptera: Hybotidae: Tachydromiinae), with description of a new species of Tachypeza Meigen from Canada and USA. Russian Entomological Journal 27 (4): 425-434.

https://doi.org/10.15298/rusentj.27.4.10

Simon C., Frati F., Beckenbach A., Crespi B.J., Liu H. \& Flook P. 1994. Evolution, weighting, and phylogenetic utility of mitochondrial gene sequences and a compilation of conserved polymerase chain reaction primers. Annals of the Entomological Society of America 87: 651-701.

https://doi.org/10.1093/aesa/87.6.651

Sinclair B. \& Cumming J. 2006. The morphology, higher-level phylogeny and classification of the Empidoidea (Diptera). Zootaxa 1180: 1-172. https://doi.org/10.11646/zootaxa.1180.1.1

Stark A. \& Doczkal D. 2017. Tachydromia wendti spec. nov. (Diptera, Empidoidea, Hybotidae) from riverbeds at the Northern slope of the Alps and its forelands in Germany. Mauritiana (Altenburg) 34: $481-498$.

Su K., Kutty S. \& Meier R., 2008. Morphology versus molecules: the phylogenetic relationships of Sepsidae (Diptera: Cyclorrhapha) based on morphology and DNA sequence data from ten genes. Cladistics 24 (6): 902-916.

Wahlberg E. \& Johanson K.A. 2018. Molecular phylogenetics reveals novel relationships within Empidoidea (Diptera). Systematic Entomology 43: 610-636. https://doi.org/10.1111/syen.12297

Zwickl D.J. 2006. Genetic Algorithm Approaches for the Phylogenetic Analysis of large biological Sequence Datasets under the Maximum Likelihood Criterion. PhD thesis, The University of Texas, Austin, USA.

Manuscript received: 23 November 2019

Manuscript accepted: 9 November 2020

Published on: 25 January 2021

Topic editor: Nesrine Akkari

Section editor: Torbjørn Ekrem

Desk editor: Kristiaan Hoedemakers

Printed versions of all papers are also deposited in the libraries of the institutes that are members of the EJT consortium: Muséum national d'histoire naturelle, Paris, France; Meise Botanic Garden, Belgium; Royal Museum for Central Africa, Tervuren, Belgium; Royal Belgian Institute of Natural Sciences, Brussels, Belgium; Natural History Museum of Denmark, Copenhagen, Denmark; Naturalis Biodiversity Center, Leiden, the Netherlands; Museo Nacional de Ciencias Naturales-CSIC, Madrid, Spain; Real Jardín Botánico de Madrid CSIC, Spain; Zoological Research Museum Alexander Koenig, Bonn, Germany; National Museum, Prague, Czech Republic. 


\section{Supplementary material:}

Supp. file 1: Fig.1. Maximum-likelihood tree based on the combined dataset (COI, trimmed 28S, 12S, AATS and PGD) using Garli ver. 2.01.1067 and the structural alignment for 28S. Bootstrap support values are depicted at the nodes (only $>50$ or $>0.5$, respectively). $\mathrm{BS}=$ Bootstrap support values. A greyscale is used to highlight the ingroup, where the darkest shade of grey highlights the Iberian flightless ant-like Tachydromia species, followed by a lighter shade which includes T. apterygon, hence representing all the flightless species occurring in southern Europe and, finally, the lighter shade covers all Tachydromia analysed, including the macropterous species assigned to different species-groups sensu Chvála (1970).

Fig. 2. Bayesian Inference tree based on the combined dataset (COI, trimmed 28S, 12S, AATS and PGD) using MrBayes ver. 3.2.6 and the structural alignment for 28S. Bayesian posterior probabilities are depicted at the nodes (only $>50$ or $>0.5$, respectively). $\mathrm{PP}=$ Bayesian posterior probabilities. A greyscale is used to highlight the ingroup, where the darkest shade of grey highlights the Iberian flightless ant-like Tachydromia species, followed by a lighter shade which includes T. apterygon, hence representing all the flightess species occurring in southern Europe and, finally, the lighter shade covers all Tachydromia analysed, including the macropterous species assigned to different species-groups sensu Chvála (1970). https://doi.org/10.5852/ejt.2021.732.1213.3459

Supp.file 2: Structural alignment of 28S before trimming.https://doi.org/10.5852/ejt.2021.732.1213.3461

Supp. file 3: Structural alignment of 28S after trimming. https://doi.org/10.5852/ejt.2021.732.1213.3463

Supp. file 4: Full alignment of all sequences included in this study, containing the non- trimmed 28S. https://doi.org/10.5852/ejt.2021.732.1213.3465

Supp. file 5: Full alignment of all sequences included in this study, containing the trimmed 28S. https://doi.org/10.5852/ejt.2021.732.1213.3467 